\title{
APPLICATION OF SPATIAL RESOURCE DATA TO ASSIST IN FARMLAND \\ VALUATION
}

by

Stephanus David Naudé

Thesis presented in partial fulfilment of the requirements for the degree of Master of Agricultural Science at Stellenbosch University

Promoters: Prof. T.E. Kleynhans, Dr. A. van Niekerk, Dr. F. Ellis Faculty of Agricultural Sciences Department of Agricultural Economics

December 2011 


\section{DECLARATION}

By submitting this thesis electronically, I declare that the entirety of the work contained therein is my own, original work, that I am the authorship owner thereof (unless to the extent explicitly otherwise stated) and that I have not previously in its entirety or in part submitted it for obtaining any qualification.

Date:

Copyright @ 2011 Stellenbosch University

All rights reserved 


\title{
APPLICATION OF SPATIAL RESOURCE DATA TO ASSIST IN FARMLAND VALUATION
}

By

\author{
Stephanus David Naudé
}

Degree: $\quad$ MSc Agric

Department: Agricultural Economics

Promoters: Prof. T.E. Kleynhans

$$
\begin{aligned}
& \text { Dr. A. van Niekerk } \\
& \text { Dr. F. Ellis }
\end{aligned}
$$

In South Africa more than 80 percent of the total land area is used for agriculture and subsistence livelihoods. A land transaction is generally not a recurring action for most buyers and sellers, their experience and knowledge are limited, for this reason the services of property agents and valuers are sometimes used, just to get more information available. The condition of insufficient information and the inability to observe differences in land productivity gives rise to the undervaluation of good land and overvaluation of poor land. The value of a property plays an important role in the acquisition of a bond, in this context farm valuations are essential and therefore commercial banks make more use of specialist businesses that have professional valuers available.

The advent of the Internet made access to comprehensive information sources easier for property agents and valuers whose critical time and resources can now be effectively managed through Geographic Information System (GIS) integrated workflow processes. This study aims to develop the blueprint for a farm valuation support system (FVSS) that assists valuers in their application of the comparable sales method by enabling them to do the following: (1) Rapid identification of the 
location of the subject property and transaction properties on an electronic map. (2) Comparison of the subject property with the transaction properties in terms of value contributing attributes that can be expressed in a spatial format, mainly a) location and b) land resource quality factors not considered in existing valuation systems that primarily focus on residential property.

Interpretation of soil characteristics to determine the suitability of a soil for annual or perennial crops requires specialized knowledge of soil scientists, knowledge not normally found among property valuers or estate agents. For this reason an algorithm, that generates an index value, was developed to allow easy comparison of the land of a subject property and that of transaction properties. Whether this index value reflects the soil suitability of different areas sufficiently accurate was confirmed by soil suitability data of the Breede and Berg River areas, which were obtained by soil scientists by means of a reconnaissance soil survey. This index value distinguishes the proposed FVSS from other existing property valuation systems and can therefore be used by valuers as a first approximation of a property's soil suitability, before doing further field work.

A nationwide survey was done among valuers and estate agents that provided information for the design of the proposed FVSS and proved that the need for such a system does exist and that it will be used by valuers. 


\section{OPSOMMING}

Meer as 80 persent van die totale grondoppervlakte in Suid-Afrika word gebruik vir landbou en bestaansboerdery. ' $n$ Grondtransaksie is oor die algemeen nie 'n herhalende aksie vir die meeste kopers en verkopers nie, hul ervaring en kennis is beperk, om hierdie rede word die dienste van eiendomsagente en waardeerders soms gebruik om meer inligting beskikbaar te kry. Die toestand van onvoldoende inligting en die onvermoë om verskille in grondproduktiwiteit te identifiseer gee aanleiding tot die onderwaardering van goeie grond en oorwaardering van swak grond. Die waarde van ' $n$ eiendom speel ' $n$ belangrike rol in die verkryging van ' $n$ verband. In hierdie konteks is plaaswaardasies noodsaaklik en daarom maak kommersiële banke meer gebruik van gespesialiseerde maatskappye wat oor professionele waardeerders beskik.

Die koms van die Internet het toegang tot omvattende inligtingsbronne makliker gemaak vir eiendomsagente en waardeerders wie se kritiese tyd en hulpbronne nou effektief bestuur kan word deur middel van Geografiese Inligtingstelsel (GIS) geïntegreerde werksprosesse. Hierdie studie poog om die bloudruk vir 'n plaaswaardasie ondersteuningstelsel te ontwikkel wat waardeerders sal help in hul toepassing van die vergelykbare verkope metode deur hul in staat te stel om die volgende te doen: (1) Vinnige identifisering van die ligging van die betrokke onderwerp eiendom en transaksie eiendomme op 'n elektroniese kaart. (2) Vergelyking van die onderwerp eiendom met transaksie eiendomme in terme van waardedraende eienskappe wat in 'n ruimtelike formaat uitgedruk word, hoofsaaklik a) ligging en b) bodem gehaltefaktore wat nie oorweeg word in bestaande residensieel georiënteerde waardasiestelsels nie.

Interpretasie van grondeienskappe om die geskiktheid van grond vir eenjarige of meerjarige gewasse te bepaal vereis gespesialiseerde kennis van grondkundiges, kennis wat nie normaalweg gevind word onder eiendomswaardeerders of eiendomsagente nie. Om hierdie rede is ' $\mathrm{n}$ algoritme ontwikkel sodat die grond van ' $n$ onderwerp eiendom d.m.v. ' $n$ indekswaarde met transaksie eiendomme vergelyk kan word. Die indekswaarde is akkuraat genoeg bevestig toe dit vergelyk is met 
grond geskiktheidsdata wat deur grondkundiges in die Breede- en Bergrivier gebiede ingesamel is. Hierdie indekswaarde onderskei die voorgestelde plaaswaardasie ondersteuningstelsel van ander bestaande eiendom waardasiestelsels en kan dus deur waardeerders gebruik word as ' $n$ eerste bepaling van ' $n$ eiendom se grond geskiktheid, voordat verdere veldwerk gedoen word.

'n Landwye opname is gedoen onder waardeerders en eiendomsagente wat inligting voorsien het vir die ontwerp van die voorgestelde plaaswaardasie ondersteuningstelsel, asook bewys gelewer het dat daar ' $n$ behoefte aan so ' $n$ stelsel bestaan en dat dit deur waardeerders gebruik sal word. 


\section{ACKNOWLEDGEMENTS}

I would like to acknowledge the following people:

Professor Theo Kleynhans ${ }^{1}$ for his supervision and guidance, and for all his support and motivation;

Dr Freddie Ellis ${ }^{2}$ for his great support and with whom to work with is always a pleasure;

Dr Adriaan van Niekerk ${ }^{3}$ for being willing to share his GIS knowledge and experience, and for all the programming work that he did;

Garth le Roux and Ilze Boonzaaier for helping with the making of the GIS maps;

My family and friends for their loyal support and motivation

\footnotetext{
${ }^{1}$ Associate professor, Department of Agricultural Economics, Stellenbosch University, Stellenbosch, South Africa.

${ }^{2}$ Senior lecturer, Department of Soil Science, Stellenbosch University, Stellenbosch, South Africa.

${ }^{3}$ Senior lecturer, Department of Geology, Stellenbosch University, Stellenbosch, South Africa.
} 


\section{LIST OF ABBREVIATIONS AND ACRONYMS}

AGIS Agricultural Information System for South Africa

AVM Automated Valuation Model

ARC Agricultural Research Council

Area \% Percentage area of the land type covered by a specific soil series.

CMA Comparative Market Analysis

D Effective Soil Depth Rating

DGI Distributed Geographic Information

DSS Decision Support Systems

DT Depth-Texture Index Value

FDGC Federal Geographic Data Committee

FVSS Farm Valuation Support System

GIS Geographic Information System

GPS Geographic Positioning System

ha Hectare

IT Information Technology

LANs Local-Area Networks

LIMS Land Information Management System

LTSIV Land Type Suitability Index Value

max maximum

min minimum

NATCCIM National Coordination Committee for Information Management

NDA National Department of Agriculture

NMO National Mapping Organization

PDA's Provincial Departments of Agriculture

SAPTG South African Property Transfer Guide

SSIV Soil Series Index Value

SSSR Soil Series Suitability Rating

$T \quad$ Texture Class Rating

WWW Worldwide Web 


\section{TABLE OF CONTENTS}

DECLARATION .ii

ABSTRACT .iii

OPSOMMING .. $\mathrm{V}$

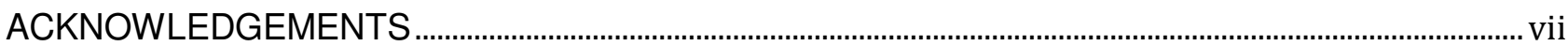

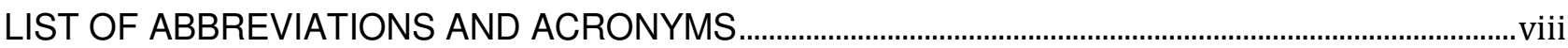

LIST OF TABLES

LIST OF FIGURES

1. INTRODUCTION AND ORIENTATION

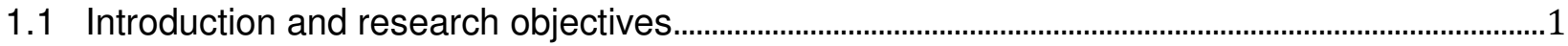

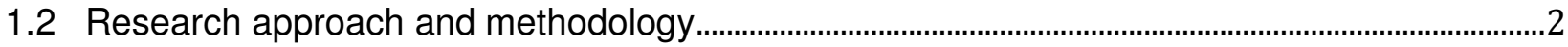

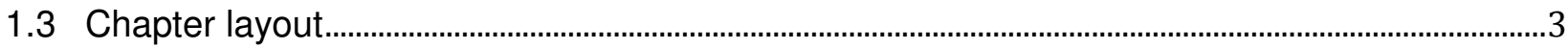

2. LITERATURE REVIEW ..............................................................................................................

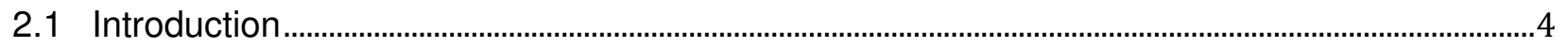

2.2 Land valuation - Fundamental valuation theory with regard to the comparable sales

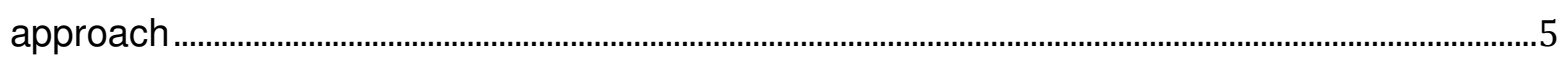

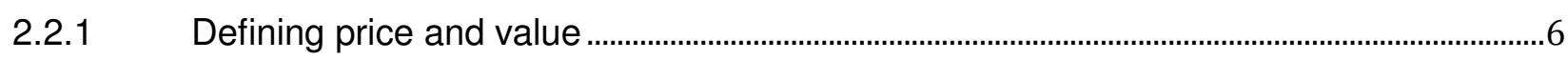

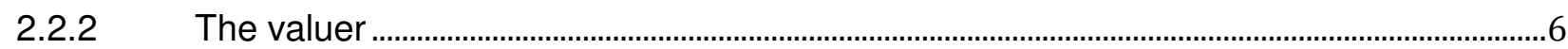

2.2.3 The open market and market value as basis for all valuations ................................................7

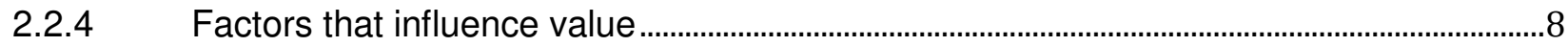

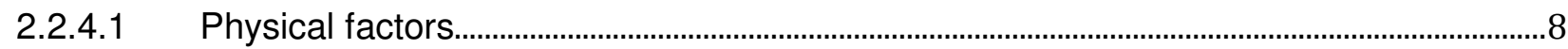

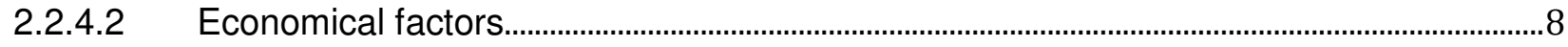

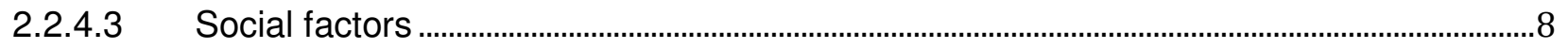

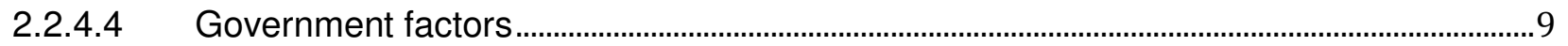

2.2.5 Interpretation of the value bearing factors according to the typical buyer and

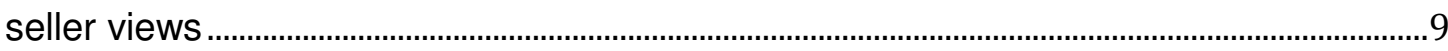

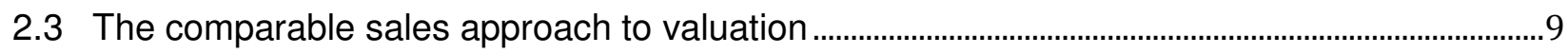

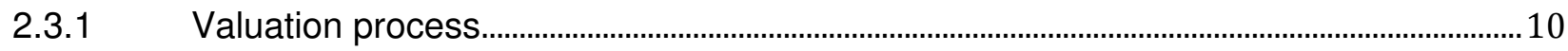

2.3.1.1 Procedure followed in the application of the comparable sales method ........................11

2.3.1.2 Principles applied in the comparable sales method.................................................................12 
2.3.1.3 The adjustment process .13

2.4 Comparing the comparable sales method with other methods of valuation................................ 14

2.4.1 Overview of the comparable sales method ..........................................................................14

2.4.2 Comparison with other valuation approaches.........................................................................15

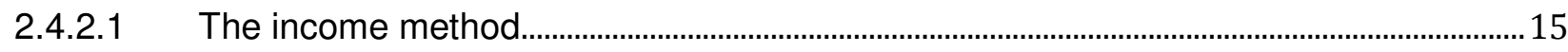

2.4.2.2 The cost method .................................................................................................................

2.5 The use of Hedonic Pricing Modelling to determine the characteristics of land.......................16

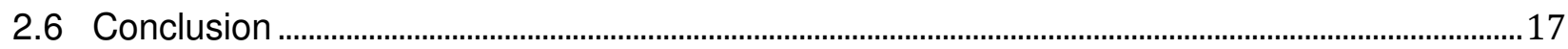

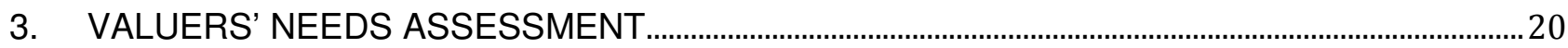

3.1 Status, gender, age and locality of the valuers in the sample .....................................................20

3.2 Valuers' average experience regarding farm property valuation........................................................21

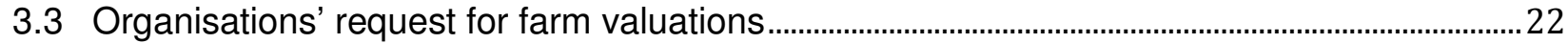

3.4 Indication of the need for a farm valuation support system and the benefits thereof ..............22

3.5 Valuers' preference regarding the 'cleaning' of properties................................................................23

3.6 An indication of valuers' computer connection preference and GIS skills...................................24

3.7 Valuers' importance-rating of available spatial data sets to compare the subject property with transaction properties..................................................................................................24

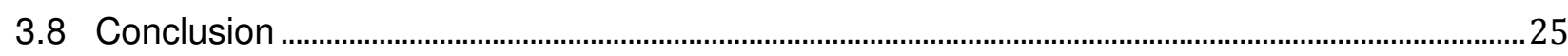

4. INCORPORATION OF GIS IN THE VALUATION PROCESS …......................................................26

4.1 GIS data implementation and application in agriculture …..........................................................26

4.2 Web-based versus Desktop Spatial Decision Support System (SDSS) for farmland

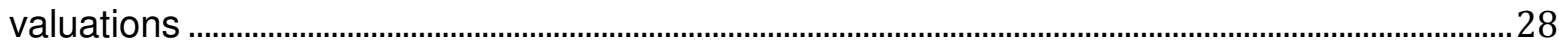

4.3 The Potential of WebGIS .................................................................................................................... 30

4.4 Property valuation software

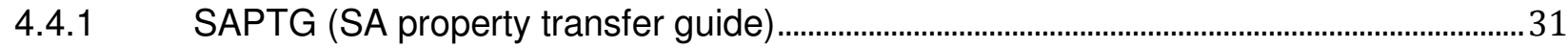

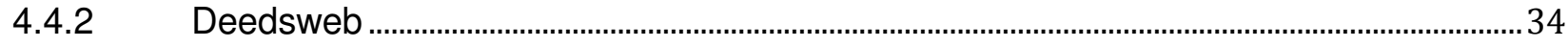

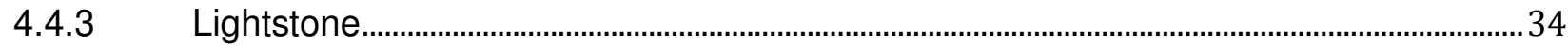

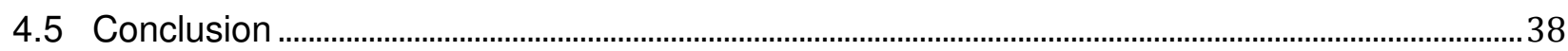

5. INCORPORATION OF LAND AND SOIL SUITABILITY INFORMATION ...........................................

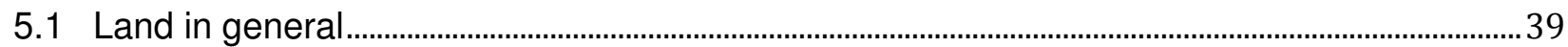

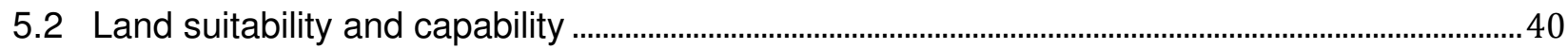

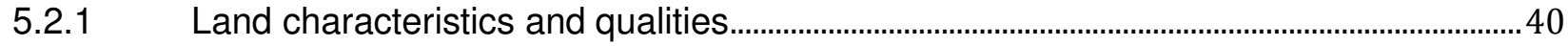




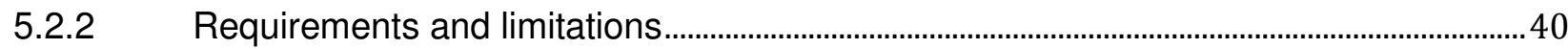

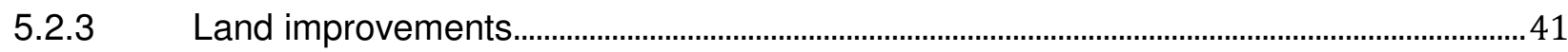

5.3 The development of a farm valuation support system (FVSS) that incorporates soil

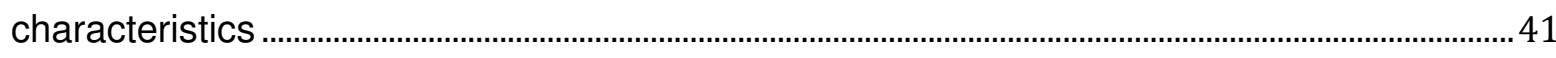

5.3.1 Soil characteristics and the suitability of a land type.............................................................42

5.3.2 Calculating the Land Type Suitability Index Value (LTSIV) ................................................43

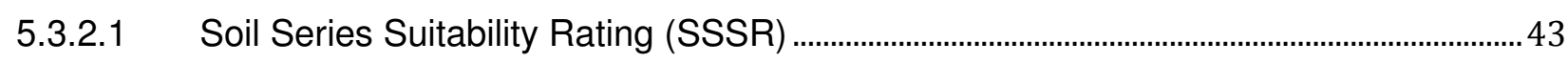

5.3.2.2 Effective Soil Depth Rating ................................................................................................. 44

5.3.2.3 Texture Class Rating ................................................................................................................ 44

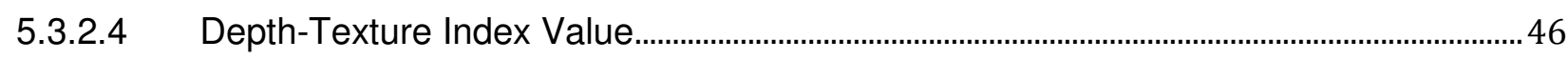

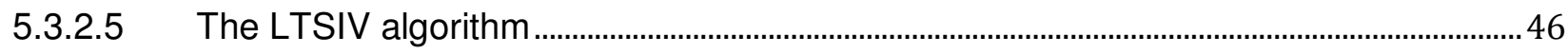

5.3.3 Comparing five different LTSIV'S............................................................................................

5.3.4 Valuing a farm property with the help of the proposed FVSS.............................................48

5.4 Information included in the proposed FVSS database .....................................................................53

5.4.1 Land type coverage, LTSIV, property extent and GPS coordinates ................................53

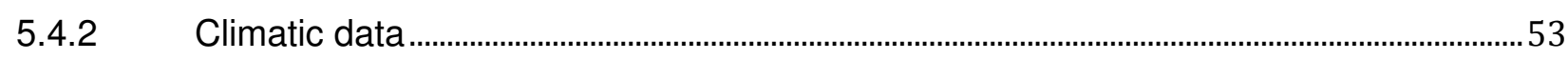

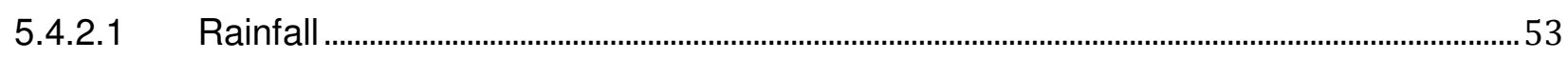

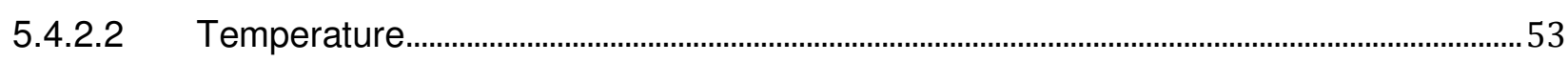

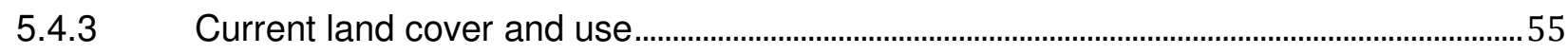

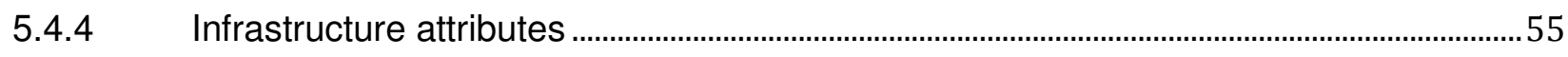

5.4.5 Topography ........................................................................................................................... 55

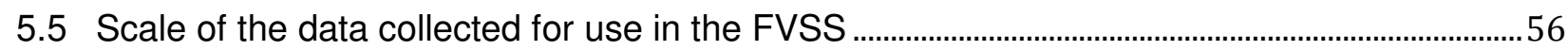

5.6 Validation of the LTSIV algorithm's accuracy for inclusion in the FVSS ......................................57

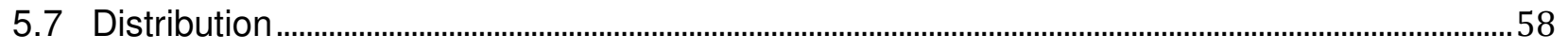

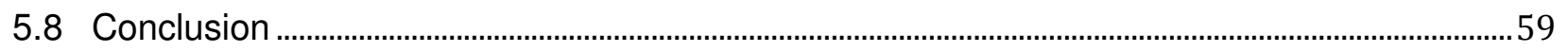

6. CONCLUSIONS AND SUMMARY

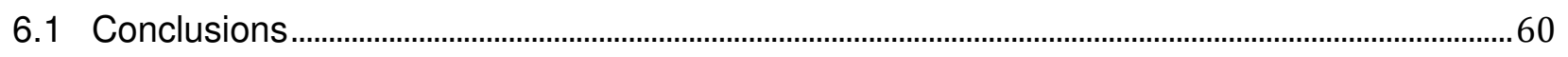

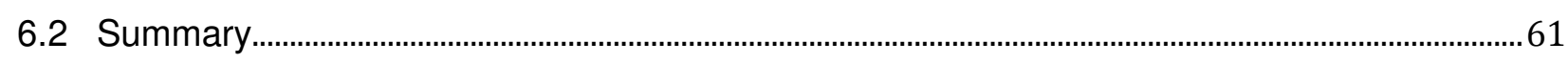

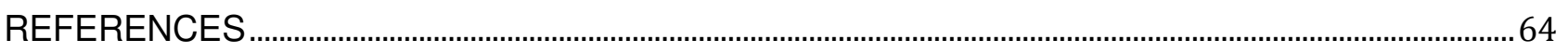

APPENDICES 


\section{LIST OF TABLES}

Table 1: Example of steps of a farm valuation. 12

Table 2: Characteristics of farms appreciated by lifestyle buyers 18

Table 3: Province where respondents of the valuer survey live and work 21

Table 4: Valuers' average self rated computer skills.............................................................................. 24

Table 5: Interpretation of the soil series suitability rating (SSSR) ................................................... 43

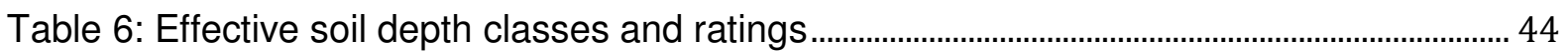

Table 7: Particle sizes of the main soil texture types........................................................................... 45

Table 8: Effect of texture class on various soil properties................................................................ 45

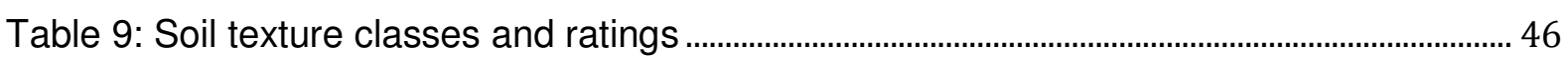

Table 10: LTSIV calculation table of land type Ab16 (random selection)....................................... 47

Table 11: LTSIV's of the five land types investigated...................................................................... 47

Table 12: Subject and transaction property information table ........................................................... 51

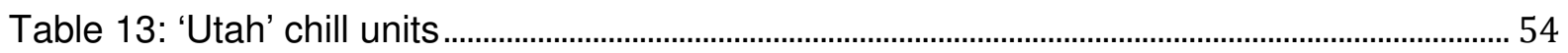

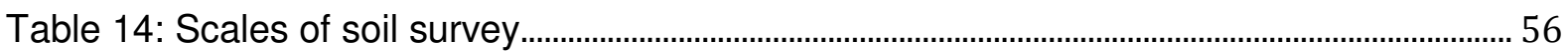

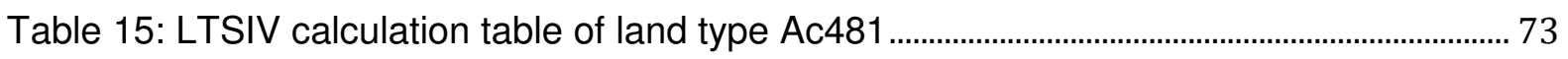

Table 16: LTSIV calculation table of land type Ca38

Table 17: LTSIV calculation table of land type Fb544 .......................................................................... 74

Table 18: LTSIV calculation table of land type Ha11 …....................................................................... 74 


\section{LIST OF FIGURES}

Figure 1: A diagrammatic representation of the valuation process............................................ 11

Figure 2: Sex and average age of the respondents of the valuer survey...................................... 20

Figure 3: Valuers' level of experience in valuation of farm and non-farm properties................ 21

Figure 4: Organisations' request for farm valuations ............................................................................. 22

Figure 5: Valuers using Winxfer or Lightstone to find farms or smallholdings............................ 23

Figure 6: Valuers' importance-rating of spatial data sets for valuation purposes........................ 25

Figure 7: SAPTG's AVM Report containing valuable residential property information............. 33

Figure 8: Property details and aerial photograph included in Lightstone's property report.... 37

Figure 9: Comparable sale's information included in Lightstone's property report..................... 38

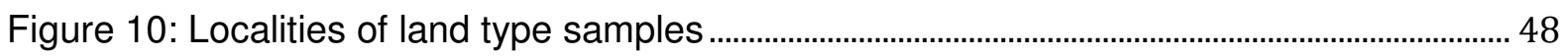

Figure 11: Spatial display of subject and transaction properties on an electronic map .......... 49

Figure 12: A detailed view of a selected property (subject property: 9/697) ................................. 50

Figure 13: Deviation between the Breede River soil survey data and the LTSIV results........ 57

Figure 14: Deviation between the Berg River soil survey data and the LTSIV results ............. 58 


\section{INTRODUCTION AND ORIENTATION}

\subsection{Introduction and research objectives}

Farm valuations are normally done by using the comparable sales method. This requires the comparison of the farm to be valued (the so-called "subject property") with comparable farms sold in the area (the so-called "transaction properties"). Transaction properties in a district are identified from Deeds Office records. Valuers normally use hard copy maps to find the location of the subject property and transaction properties. This process can be quite time consuming. The location of such properties can also be determined by using digital spatial data sets, but this requires knowledge of Geographic Information System (GIS) computer software. GIS software have a wide range of tools available to determine, record and disseminate information about ownership, land registration, cadastre, valuation and land inventory. Few, if any, valuers are GIS literate.

This study aims to develop the blueprint for a farm valuation support system (FVSS) that assists valuers in their application of the comparable sales method by enabling them to do the following:

1. Rapid identification of the location of the subject property and transaction properties on an electronic map.

2. Comparison of the subject property with the transaction properties in terms of value contributing attributes that can be expressed in a spatial format, mainly a) location and b) land resource quality factors.

a) Assessment of the location of the subject property relative to that of the transaction properties can be determined by evaluating the accessibility of the subject and transaction properties relative to the existing road and rail infrastructure and towns and cities. The transport infrastructure digital data set is available and is used for transport planning purposes.

b) Comparison of the subject property with the transaction properties based on land resource quality attributes. Various digital data sets were developed over many years to assist agricultural planning, for example precipitation and 
temperature maps, topography, soils and land-use maps. These maps can be used effectively to compare e.g. the climate, terrain and soil characteristics of the subject property with that of the transaction properties.

3. Interpretation of soil characteristics to determine the suitability of a soil for annual or perennial crops requires specialized knowledge of soil scientists, knowledge not normally found among property valuers or estate agents. For this reason an algorithm, that generates an index value, was developed to allow easy comparison of the land of a subject property and that of transaction properties. Determining whether this index value reflects the soil suitability of different areas sufficiently accurate, in order to serve as a basis for comparison of the subject property with transaction properties, forms a major part of this investigation.

The result of this study should provide a blueprint to operationalize a farm valuation support system to be used by farm valuers and also farm estate agents in South Africa. The FVSS can be a useful starting point to facilitate the field visit. The FVSS aims to provide a reference framework for the valuer to provide information about the subject and transaction properties, mainly to sensitize the valuer with regard to possible differences or similarities between the subject property and the transaction properties in terms of relevant value bearing attributes. This may enhance the quality of the valuation and should save time. It would not replace valuers' visits and thorough inspection of properties and does not aim to automate the valuation process.

\subsection{Research approach and methodology}

Guidelines for the design of the proposed FVSS are determined by means of a nationwide survey among valuers and estate agents specialising in farm valuations. An algorithm, that generates a Land Type Suitability Index Value (LTSIV), is then developed with the help of soil scientists. Soil suitability data of the Breede and Berg River areas is compared with the LTSIV to determine whether this index value reflects the soil suitability of different areas sufficiently accurate. A blueprint of the FVSS is then created. 


\subsection{Chapter layout}

This study is presented in six chapters, followed by a list of references and annexures. The first chapter serves to structure and orientate the study and as a general introduction.

It is followed by Chapter 2, the 'Literature Review', which reviews scientific articles and books relating to the scope of this study. Firstly, it gives a general introduction to the literature on land valuation, followed by sections covering the literature on fundamental valuation theory with regard to the comparable sales approach. Further literature reviews are presented concerning the comparable sales method of valuation and its comparison with the income and cost methods of valuation.

Chapter 3 includes a nationwide survey among valuers and estate agents specialising in farm valuations. The aim of the survey is to collect information to provide guidelines for the design of a farm valuation support system that will enable the valuer to compare a subject farm with transaction farms with respect to relevant value bearing attributes.

Chapter 4 firstly gives a general introduction to Geographical Information Systems (GIS) and its implementation and application in agriculture. Following is a review of the most efficient way to distribute information by comparing PC-based Decision Support Systems (DSS) with web-based DSS, as well as an investigation of the potential of Web-GIS. The chapter also focuses on the abilities and limitations of already existing property valuation software with regard to farm valuations.

Chapter 5 deals with the development, functionality and validation of the proposed FVSS. Firstly, factors affecting farm land suitability is reviewed. Secondly the chapter focuses on identifying and incorporating specific soil characteristics into an algorithm that would reveal the agricultural suitability of different land types by means of an index value. The validation of this algorithm's accuracy follows later on in this chapter. Thirdly, the chapter reveals the functionality and use of the FVSS to the valuer. It also gives the type and scale of data sets included in the FVSS.

The last chapter comprises of the conclusions and a summary. 


\section{LITERATURE REVIEW}

\subsection{Introduction}

In South Africa more than $80 \%$ (100m ha) of the total land area of $121.9 \mathrm{~m}$ ha is used for agriculture and subsistence livelihoods. However, only about $11 \%$ is arable, the remainder is used for grazing (DEAT, 2006). A farm is the physical land and the attachments on it, it is also an economic product because it can be managed productively and is scarce relatively to the demand thereof. As a scarce economic product it obtains the attribute "value" which means that people will be willing to compete for ownership, it is therefore mostly the claim in court and most expensive single investment which the farm owner makes (Burger, 1990:66).

In land valuation it is a common understanding that the value and potential of a property are fundamentally determined by its location and land quality and this emphasizes the significance of spatial factors in the decision making process. Each farm is naturally unique in the sense that they differ in location, size, land quality and extent of improvements. Farms therefore normally sell slowly and with difficulty. The market for farms is mostly limited and often unorganized.

When farm sales occur, it can be very dispersed in terms of both geography and time and most vendors come to the market infrequently and usually have limited knowledge (Burger, 1990:69). A land transaction is generally not a recurring action for most buyers and sellers, their experience and knowledge are limited, for this reason the services of property agents and valuers are sometimes used, just to get more information available (Lombard, 1993:85). The condition of insufficient information and the inability to observe differences in land productivity gives rise to the undervaluation of good land and overvaluation of poor land (Boehlje \& Eidman, 1984:531).

The advent of the Internet made access to comprehensive information sources easier for property agents and valuers whose critical time and resources can now be effectively managed through GIS integrated workflow processes (McFetridge, 2008:7). The development in Information Technology (IT) has greatly reduced the gap between information users and producers. Information is easily reachable in 
distributed database environments in order to integrate, query and spread various spatial data sets through the networks. A global trend is the merging of two different Web-based devices, the process is referred to as "mash-ups". An example is the linkage of a property agency with Google Earth so that a real-time map can easily illustrate properties and their activities (Friedman, 2006:287-288).

Since land is not a homogeneous product, local inspection is required to inform potential buyers about the product and the market (Lombard, 1993:85). When valuing a farm the valuer has to spend sufficient time to review land maps, inspect the farm, examine soil types, check irrigation- and drainage facilities, make an inventory of buildings and fixed improvements and visit the neighbouring farms (Burger, 1990:36). Valuable time may be wasted by the valuer travelling to transaction farms not comparable with the subject property. A FVSS will improve the valuer's 'cleaning' ${ }^{4}$ of transaction farms and therefore much time will be saved as the logistical planning of his/her field visit will only include sufficiently comparable transaction farms.

\subsection{Land valuation - Fundamental valuation theory with regard to the comparable sales approach}

A farm valuation is a clearly defined and motivated detailed estimate of the value of a farm. The process and the detail in which the valuation will be done depends on the purpose of the valuation (Burger, 1990:58).

There are many purposes for farm valuation, but the most common are for:

- Security for farm loans: provide up-to-date valuation of farm property.

- Purchase and sale: a detailed market valuation can serve a buyer or a seller, because a valuation by a competent valuer includes all important factors affecting a farm's value, unfavourable as well as favourable.

- Tax assessment: actual rating of all farms or tracts in a district.

\footnotetext{
${ }^{4}$ Selection process where the valuer narrow down the potentially comparable properties by excluding non arm's length transactions or transaction properties with an extent that differs too much from that of the subject property.
} 
- Expropriation: fair market value is the general standard used in providing compensation to owners in expropriation cases.

- Other types: among the other types of valuation are those for estate and inheritance taxes, book value (book keeping purposes or insurance cover) and easements (Murray, 1969:4-7).

\subsubsection{Defining price and value}

'Value' is measured by comparing objects with each other and 'price' is measured by the value of the trade (Murray, 1969:31). "Price is a term used for the amount asked, offered, or paid for a good or service. Value is an economic concept referring to the price most likely to be concluded by the buyers and sellers of a good or service that is available for purchase. Value is not a fact, but an estimate of the likely price to be paid for goods and services at a given time in accordance with a particular definition of value. The economic concept of value reflects a market's view of the benefits that accrue to one who owns the goods or receives the services as of the effective date of valuation" (International Valuation Standards, 2005:25-26).

A valuer making use of the comparable sales method of valuation can establish a price guideline by synchronising transaction property prices with their value bearing attributes. This price guideline can then be synchronised with the value bearing attributes of the subject property in order to determine its value.

\subsubsection{The valuer}

A valuer is defined as one who officially estimates the worth, value or quality of things (Lewis, 2007). Webb (1994:1) has found that it appears that values as determined by valuers lag market prices during a property cycle, but that nothing is necessarily wrong with the valuation process. Estimation is a matter of opinion and the art of formulating such opinion, if it is to be respected, depend on a variety of considerations (Ellenberger, 1983:1). It seems that valuers are judged too much on their value estimates and not enough on the criteria behind those estimates (Dent \& Temple, 1998:5). 
The influence of upbringing, education and experience on the mind of the valuer is highlighted in the following passage: "Evaluation starts with the mind of the valuer. The mind is, in essence, an information handling system. It gathers this information as codes and then interweaves these into patterns which aid interpretation and recall. The patterns themselves are artificially created by the mind and as such are not necessarily based on any rational criteria. They are preconceived notions which have often been built up through a combination of upbringing, education and experience. However, the patterns are unconsciously employed in the process of taking decisions in everyday life" (Dent \& Temple, 1998:4).

\subsubsection{The open market and market value as basis for all valuations}

The definition of "market" contains four main concepts namely, supply, demand, buyers and sellers, who agree on a price through interaction and finalising it with a contract (De Jongh, 1975:20). Market value is defined as: "The estimated amount for which a property should exchange on the date of valuation between a willing buyer and a willing seller in an arm's-length transaction after proper marketing wherein the parties had each acted knowledgeably, prudently, and without compulsion" (International Valuation Standards, 2005:27).

The basis of the value of a farm is the utility/use thereof for the owner (Burger, 1990:64). The utility of agricultural land is ordinarily measured by its productive capacity. Its value is a function of the quantity and quality of produce, which the land will yield in an agricultural sense, or of the quantity and quality of buildings essential to the agricultural operation. Most properties are valued as a combination of land and improvements. In such cases, the valuer will normally estimate market value by considering the highest and best use of the property as improved. Highest and best use is defined as: "The most probable use of a property which is physically possible, appropriately justified, legally permissible, financially feasible, and which results in the highest value of the property being valued" (International Valuation Standards, 2005:29-30).

A farm is a relatively large capital investment and unique in location, size, productivity and degree of fixed improvements. Farms are sold slowly and with a lot 
of effort. Most sellers enter the market irregularly and usually have limited knowledge. Farm sales are also very sparse regarding geography and time. Due to the few participants in the market for farm land, the non-average buyer and seller may have a significant effect on the price paid for a farm (Burger, 1990:69-70).

\subsubsection{Factors that influence value}

Physical, economic and business economics, social and government factors affect value. Collectively, there is an interaction among the factors that leads to the creation of the marketplace in which a farm can be owned, used and transferred. The factors are dynamic and change over time. To investigate farm values is a commitment to estimate the influence of these factors on the price of sold farms. The focus of this study will be on the physical factors, and more specifically the utilisation of available digital spatial data on these factors, for valuation purposes.

\subsubsection{Physical factors}

Physical factors influencing the value of a farm is properties such as location, size, shape, environment, topsoil, drainage, topography, vegetation, accessibility, climate and aesthetics. The value of structures on the farm is determined by building quality, design, adaptation and harmony with the surrounding environment. Each one of the physical properties plays an important role in determining how a specific portion of the property should be used. The use to which the section will be put, has a material impact on the benefits that will go to the owner of the farm and that gives rise to property value (Burger 1990:66).

\subsubsection{Economical factors}

Economical factors affecting the value of a farm reflects how the property is interacting or fitting into the economy of the community. Factors such as community income, the availability and terms of credit, price levels, tax rates and the supply of labour represents the economical factors that affects farm values (Burger 1990:66).

\subsubsection{Social factors}

Social factors affecting the value of farms are population trends, the neighbours, architectural building styles, the usefulness of buildings and the status of the 'address' of an area. Social factors are much more subjective in nature than physical 
and business economic factors and therefore sometimes difficult to evaluate (Burger 1990:67).

\subsubsection{Government factors}

Government factors refer to the public policy of local, provincial and central authorities on farms. Control over land use does not necessarily deprive land of its potentialities, but regard must be taken to the limits and restrictions placed on land use by law (Ellenberger, 1983:44). The role of government factors in determining the value of farms should not be underestimated.

2.2.5 Interpretation of the value bearing factors according to the typical buyer and seller views

The valuer must attempt to put himself in the shoes of an imaginary informed seller and buyer, on that basis, the valuer should consider all the factors such a seller and buyer would have taken into account in the open market as well as all the information that would have been available to them. It is the duty of the valuer "...to take into consideration every circumstance likely to influence the mind of the purchaser..." (Pietermaritzburg Corporation v. S.A. Breweries Ltd., 1911:516). Circumstances that would influence the seller and the buyer in their determination of a price is not just facts duly proven, but also information provided by other people, answers to their inquiries obtained by others, general talk among the farmers of the region, and so on, on that basis a valuer is similarly entitled to his opinion based on what he heard from other people (Lornadawn Investments (PTY) Ltd. v. Minister of Agriculture, 1977:626).

\subsection{The comparable sales approach to valuation}

The major objective in farm valuation is comparison judgement. It is mainly a shift from comparing and rating individual features in a small area to comparing and rating all the features of a farm rolled into one, or of rating whole farms one with another over a large area. A judgement or rating of the farm as a whole is essential because the sum of the individual parts does not necessarily give the value of the farm as a unit. Valuation, in essence, is the art of making comparison judgements or decisions (Murray, 1969:395-396). 
The comparable sales approach estimates the current market value of a particular farm by comparing it with comparable farms sold recently. The point of departure is that the market determines the price of the particular farm in the same way as similar competitive farms. The basis of the particular farm's value is the prices paid for the comparable farms in actual market circumstances. The sales price reflects all sources of value as well as factors that influence value. The method is based on three premises:

- Each sale is represented by a minimum of two persons' discretion.

- Informed seller does not sell the specific farm for less than comparable farms in the market.

- Informed buyer does not pay more for the specific farm than for comparable farms in the market (Burger, 1990:84-85).

The implementation of the method implies firstly the selection of all comparable farms. The comparable farms' prices are then adjusted by assessing their differences to supply the basis on which the particular farm's value will be estimated (Burger, 1990:85). It is a difficult task to measure the quality of nearby sales in comparison with the farm that's being valued. The valuer's knowledge of soils, crops, and yield variations is of great help in making the comparison, the last step to determine the farm value is to adjust the different values to make the sales truly comparable (Murray, 1969:35).

\subsubsection{Valuation process}

The identified aim of the valuation is used as point of departure in the practical application of valuation methods. 


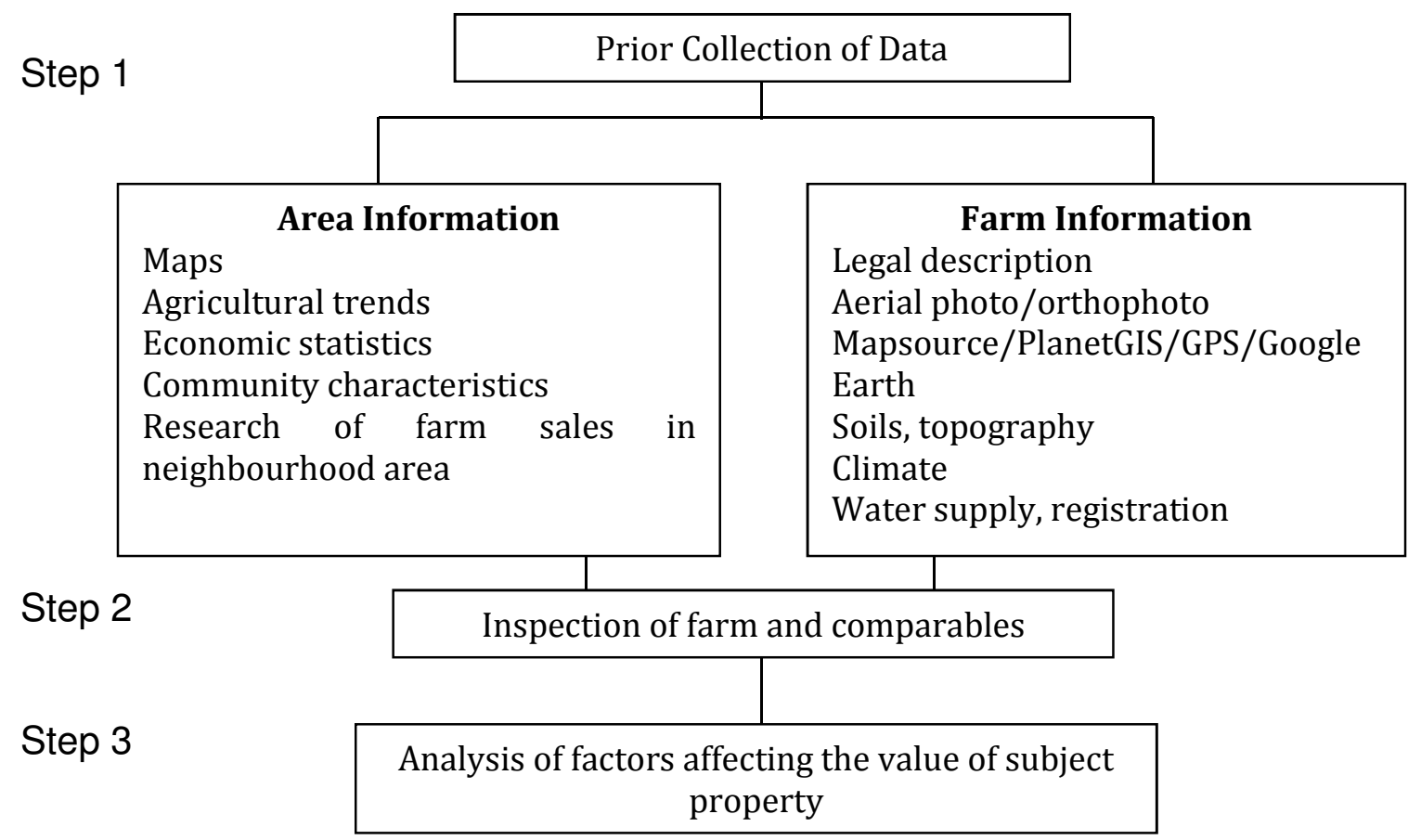

Figure 1: A diagrammatic representation of the valuation process

2.3.1.1 Procedure followed in the application of the comparable sales method

A particular systematic procedure must be followed in the application of the comparable sales method:

1. Explore the market for transactions and other presentations similar to the particular farm.

2. Verify information by checking if information retrieved is in fact correct and if the transaction took place under lawfully market relevant circumstances.

3. Determine appropriate unit of comparison.

4. Compare the particular farm with comparable farms with regard to elements of comparison and adjust sale prices thereon or reject farm as comparable.

5. Combine the multiple value-indicators given by the comparable farms with the value-indicators of the particular farm (Burger,1990:85-86). 


\section{Table 1: Example of steps of a farm valuation}

\section{CLASSIFICATION AND INVENTORY}

\section{A. Location Factors}

Location; Towns and cities; Roads; Facilities; Schools; Churches; Community; Zoning;

Recreation; Health services; Taxes; Buildings; Typical rental rates

B. Maps

C. Productivity

Tillable and non tillable land; Topography; Drainage; Soil productivity

D. Building and Inventory Value

\section{MARKET VALUE ESTIMATE}

A. Sale History of Farm

B. Comparable Sale List

C. Map Showing Location of Comparable Sales

D. Description of Comparable Sales

E. Comparison of Sales with subject property

F. Benchmark Value Chart for subject property

G. Market Value Estimate

III. INCOME VALUE ESTIMATE (IF NEEDED)
A. Income
B. Expense of Landlord
C. Valuation

\section{FINAL VALUE}
A. Market Value
B. Income Value
C. Loan Value

Source: Murray (1969:10-25)

\subsubsection{Principles applied in the comparable sales method}

- Transactions that are comparable

A transaction that is comparable can be defined as a farm that corresponds largely to the particular farm in terms of type, organization, size, location, production capacity and improvements. The definition is only valid if it was a recent transaction with sufficient competition. A transaction that is comparable is a bona fide 
transaction where both the buyer and seller acted without coercion. If the valuer has kept book of sales over the past decade, he can develop price indices of the rising or falling trend in the market. This will enable him to consider sales even further in the past, as comparable. Sales close to the particular farm are preferable, but if the farm has some unique features that further lying farms also present, it can be used as comparable criteria. Comparability can further be based on the soils and improvements (Burger, 1990:88).

- Units of comparison

Units of comparison are used by the valuer to facilitate the adjustments. Many properties can be analysed by the use of several units of comparison, and in many instances, several units are used in the valuation process. The valuer must choose the most appropriate and reliable unit of comparison for a particular property type. Price per hectare and price per square meter is generally used as units of comparison during farm property valuations (ASFMRA, accessed online: May 2011).

- Elements of comparison

Elements of comparison are the characteristics of farms that lead to varying farm prices. The following elements of comparison should be considered in the sales comparison approach:

- Real property rights conveyed

- Financing terms

- Conditions of sale

- Market conditions on date of sale

- Location

- Physical characteristics

Adjustments for these are made to the actual selling price of the comparable property (Friedman \& Lindeman, 2005:216).

\subsubsection{The adjustment process}

Adjustments may be made in terms of percentages or in rand amounts. Either the total sales price may be adjusted or the adjustments can be applied to one or more units of comparison. The adjustments should be made in sequential order, with the adjustment for real property rights always made first, the adjustment for financing 
terms then made to the sales price adjusted for real property rights conveyed, and so on. Adjustments for location and physical characteristics are interrelated or interdependent, then cumulative percentage adjustments may be used. If they are independent, however, each should be applied to the actual price of the comparable property (Friedman \& Lindeman, 2005:217).

\subsection{Comparing the comparable sales method with other methods of valuation}

\subsubsection{Overview of the comparable sales method}

Premise

- Market value of a particular farm can be estimated by adjusting sale prices of comparable sales according to characteristics of the particular farm.

Advantages

- The basis for the method is actual sales and prices paid for comparable circumstances.

- The method is grounded on easy-to-understand principles and does not make use of complex mathematical models.

Drawbacks - The main drawbacks are the following:

- When the value of the relevant farm is derived from the selling prices of comparable farms, inevitably there is subjectivity involved. The greater the difference and the adjustment that must be made, the greater the degree of subjectivity involved.

- With a lack of comparability, the applicability of the method is limited.

- Certain types of farms are rarely if ever sold, and although a market for it exists, it functions slowly and to a limited extent. The result is that the market information which is obtained thereof is insufficient to make an estimate based on it. Historic farms are a good example.

- Time adjustments for sales under new market conditions can be a very difficult and highly subjective task.

- All information regarding a sales transaction is not readily available and therefore it's not always possible to determine whether a transaction was in good faith or not. 
- The costs incurred to obtain the latest market information often rise so sharply relative to the increase in accuracy, that it's not justified (Burger, 1990:129132).

\subsubsection{Comparison with other valuation approaches}

There are two more approaches to be mentioned: the income and cost approaches. Comparable sales seems to be the principal approach in farm valuation because it includes both income, cost and non-income features of a farm (Murray, 1969:39).

\subsubsection{The income method}

This approach date as far back as 1693, but truly evolved in the 1930's. The income value of a property can be estimated through market inference or by discounting a farm's income stream. The key of this method is the relation between a farm's value and the income stream it generates, a buyer thus buys the future income stream. The method can be applied in two ways: (1) the method of comparable yield rate and (2) discounting cash flow analysis (Burger, 1990:105).

In practice it often happens that only a few or no truly comparable farms occur and in such a case the method of discounted cash flow analysis is used. A reliable estimate of the normalized net income of the farm must be made. Then the problem is to determine an appropriate discount rate. The method does take growth and risk into account when the normalized net income flow is calculated, but an important drawback is that the projection of the future income flow is made by some mathematical formula. Comparatively, the method of discounted cash flow analysis is focused more on the particular farm with its unique characteristics, although the South African courts are highly sceptical about the method due to the large number of assumptions that must be made (Burger, 1990:105).

Land value is thus calculated as the capitalized residue after first providing compensation for other factors of production on grounds of agricultural or productive value. The drawback is the fact that land prices in several districts are much higher than its productive value, as a result the income method is an inaccurate value guide, especially because of non-productive features such as aesthetic value, 
historical value and status which are important for lifestyle buyers ${ }^{5}$. The comparable sales method accommodates this drawback because it incorporates a broader consideration than just the productivity characteristics of a farm. The value system adopted for the last 400 years is based on monetary value, limiting consideration of the qualitative elements of decision making for investment (Dent \& Temple, 1998:7). These qualitative elements that are associated with lifestyle buyers have been identified by Reed (2009) and should be used by valuers as a decision support tool (“check list”) when valuing a farm (Table 2).

\subsubsection{The cost method}

The cost method should be used very cautiously and only in cases where buildings and improvements constitute a large percentage of the farm or where both the income and comparable sales methods are not appropriate to use. The method is seen as a control measure of the income and comparable sales method. The major drawback of this method is the fact that cost and value are not similar concepts and to derive market value only from a cost perspective is not good enough (Burger, 1990:129).

Not one of the three methods of valuation is at all times the best method. A combination of the three methods is more efficient. The ideal is that each method must be used as detailed as possible to determine value. If possible, each method should only be used to verify the final value of the different methods of calculation. This is problematic because many of the fundamental facts of the respective methods are often similar (Burger, 1990:132-133).

\subsection{The use of Hedonic Pricing Modelling to determine the characteristics of land}

The hedonic technique is based on the premise that goods traded in the market are made up of different bundles of attributes or characteristics. Hedonic price models (HPM), including Geographic Information System (GIS) delineated variables, permit inferring the impact of land attributes on land values. Agricultural land values can be

\footnotetext{
${ }^{5}$ Lifestyle buyers recognise that agricultural land has a variety of uses, for them, income is not the only consideration.
} 
estimated by summing the discounted productive rents. This approach may reflect soil quality, capital improvements, water supply and location to markets, however, remote agricultural lands, which include wildlife habitat, angling opportunities and scenic vistas, command higher prices per hectare than those which primarily possess agricultural production capacity (Bastian et al., 2002: 338,346). For this reason agricultural land in specific areas derives its value from a combination of productive and non-productive attributes (Spahr and Sunderman, 1999:233).

\subsection{Conclusion}

This chapter covered literature on fundamental valuation theory with regard to the comparable sales approach, as well as literature concerning the comparable sales method of valuation and its comparison with the income and cost methods of valuation. The literature revealed that although the comparable sales method of valuation has its shortcomings, it is clearly the best method used by valuers, especially in the field of farm property valuation. This chapter also clearly stated that valuers should incorporate a farm's non-productive attributes in the valuation process. The next chapter contains a valuer survey analysis which will reveal important value bearing attributes that can be used for the design of a farm valuation support system. 


\section{Table 2: Characteristics of farms appreciated by lifestyle buyers in the intensive and extensive areas of the Western Cape Province}

\begin{tabular}{|c|c|c|c|}
\hline Characteristic & $\begin{array}{l}\text { Intensive } \\
\text { area }\end{array}$ & $\begin{array}{l}\text { Extensive } \\
\text { area }\end{array}$ & $\begin{array}{l}\text { GIS-data } \\
\text { available }\end{array}$ \\
\hline Location: proximity to nearest city & $\sqrt{ }$ & $\sqrt{ }$ & Yes \\
\hline Location: proximity to nearest town & $\sqrt{ }$ & & Yes \\
\hline Location: proximity to nearest airport & $\sqrt{ }$ & & Yes \\
\hline Location: proximity to nearest major road & $\sqrt{ }$ & & Yes \\
\hline Location: travelling time & $\sqrt{ }$ & $\sqrt{ }$ & - \\
\hline Access: for tourists & $\sqrt{ }$ & & - \\
\hline Position: setting (in valley, against mountain) & $\sqrt{ }$ & $\sqrt{ }$ & - \\
\hline Position: private & $\sqrt{ }$ & $\sqrt{ }$ & - \\
\hline Production potential: soil quality & $\sqrt{ }$ & $\sqrt{ }$ & Yes \\
\hline Production potential: meso climate & $\sqrt{ }$ & $\sqrt{ }$ & - \\
\hline Production potential: size of property & $\sqrt{ }$ & $\sqrt{ }$ & Yes \\
\hline Production potential: grazing capacity & & $\sqrt{ }$ & Yes \\
\hline Production potential: game production & & $\sqrt{ }$ & - \\
\hline Topography: varied & & $\sqrt{ }$ & Can calculate \\
\hline Water availability: human and animal consumption & $\sqrt{ }$ & $\sqrt{ }$ & - \\
\hline Water availability: irrigation & $\sqrt{ }$ & & - \\
\hline Residential infrastructure: style of main residence & $\sqrt{ }$ & & - \\
\hline Residential infrastructure: size of main residence & $\sqrt{ }$ & $\sqrt{ }$ & - \\
\hline Residential infrastructure: condition of main residence & & $\sqrt{ }$ & - \\
\hline $\begin{array}{l}\text { Residential infrastructure: accommodation capacity of other } \\
\text { residential units }\end{array}$ & $\sqrt{ }$ & & - \\
\hline Residential infrastructure: condition of other residential units & & $\sqrt{ }$ & - \\
\hline Permanent living rights for labourers & $\sqrt{ }$ & & - \\
\hline Non-residential infrastructure: capacity & $\sqrt{ }$ & & - \\
\hline Non-residential infrastructure: power supply & $\sqrt{ }$ & & - \\
\hline Non-residential infrastructure: condition & $\sqrt{ }$ & $\sqrt{ }$ & - \\
\hline $\begin{array}{l}\text { Non-residential infrastructure: condition and capacity of irrigation } \\
\text { infrastructure }\end{array}$ & $\sqrt{ }$ & & - \\
\hline Non-residential infrastructure: game fencing & & $\sqrt{ }$ & - \\
\hline \multirow{6}{*}{$\begin{array}{l}\text { Aesthetics - presence of natural scenery including: } \\
\text { Mountains } \\
\text { Peace and quiet (tranquillity) } \\
\text { Clean, fresh air } \\
\text { Wildlife } \\
\text { Openness and space }\end{array}$} & $\sqrt{ }$ & $\sqrt{ }$ & - \\
\hline & $\sqrt{ }$ & $\sqrt{ }$ & Can calculate \\
\hline & $\sqrt{ }$ & $\sqrt{ }$ & - \\
\hline & $\sqrt{ }$ & $\sqrt{ }$ & - \\
\hline & & $\sqrt{ }$ & - \\
\hline & $\sqrt{ }$ & $\sqrt{ }$ & - \\
\hline
\end{tabular}




\begin{tabular}{|c|c|c|c|}
\hline & \multirow{2}{*}{\multicolumn{3}{|c|}{ Valleys, gorges and ravines }} \\
\hline & & & \\
\hline \multirow{2}{*}{ Rock formations and rock faces } & & $\sqrt{ }$ & Can calculate \\
\hline & $\sqrt{ }$ & & - \\
\hline $\begin{array}{l}\text { Big trees, forests and bush } \\
\text { Pristine environment with vegetation typical of the area }\end{array}$ & $\sqrt{ }$ & $\sqrt{ }$ & Can calculate \\
\hline \multirow{3}{*}{$\begin{array}{l}\text { Birdlife } \\
\text { Rivers, river frontage and riparian areas } \\
\text { No sign of civilisation (such as roads and buildings) }\end{array}$} & $\sqrt{ }$ & $\sqrt{ }$ & - \\
\hline & $\sqrt{ }$ & $\sqrt{ }$ & - \\
\hline & & $\sqrt{ }$ & - \\
\hline Aesthetics: presence of river, stream, river frontage & $\sqrt{ }$ & $\sqrt{ }$ & - \\
\hline Aesthetics: presence of mountain & $\sqrt{ }$ & $\sqrt{ }$ & Can calculate \\
\hline \multirow{4}{*}{$\begin{array}{l}\text { Aesthetics: presence of beautiful view, including: } \\
\text { View of vineyards } \\
\text { View of natural veld } \\
\text { View of indigenous vegetation (such as fynbos, karoo bush) }\end{array}$} & $\sqrt{ }$ & $\sqrt{ }$ & - \\
\hline & $\sqrt{ }$ & & - \\
\hline & & $\sqrt{ }$ & - \\
\hline & & $\sqrt{ }$ & - \\
\hline \multirow{2}{*}{$\begin{array}{l}\text { View of trees } \\
\text { View of mountains and mountain ranges }\end{array}$} & $\sqrt{ }$ & & - \\
\hline & $\sqrt{ }$ & $\sqrt{ }$ & - \\
\hline \multirow{3}{*}{$\begin{array}{l}\text { View of valleys, gorges and ravines } \\
\text { View of water such as a river, stream or dam } \\
360 \text { degrees uninterrupted views }\end{array}$} & $\sqrt{ }$ & $\sqrt{ }$ & - \\
\hline & $\sqrt{ }$ & $\sqrt{ }$ & - \\
\hline & & $\sqrt{ }$ & - \\
\hline \multirow{4}{*}{$\begin{array}{l}\text { View of natural scenery } \\
\text { No Eskom power lines in sight } \\
\text { No sign of civilisation (e.g. roads, buildings) } \\
\text { View that stretches to the horizon, such as never-ending Karoo } \\
\text { plains }\end{array}$} & $\sqrt{ }$ & $\sqrt{ }$ & - \\
\hline & $\sqrt{ }$ & $\sqrt{ }$ & - \\
\hline & & $\sqrt{ }$ & - \\
\hline & & $\sqrt{ }$ & - \\
\hline View of a well-kept garden & $\sqrt{ }$ & & - \\
\hline Aesthetics: presence of indigenous vegetation & $\sqrt{ }$ & $\sqrt{ }$ & Can calculate \\
\hline Aesthetics: presence of trees & $\sqrt{ }$ & $\sqrt{ }$ & Can calculate \\
\hline Aesthetics: presence of dam or dams & $\sqrt{ }$ & $\sqrt{ }$ & Yes \\
\hline Aesthetics: presence of rural surroundings & $\sqrt{ }$ & $\sqrt{ }$ & - \\
\hline Possibility for outdoor recreation activities & $\sqrt{ }$ & $\sqrt{ }$ & Yes \\
\hline Possibility of water recreation activities & $\sqrt{ }$ & & Yes \\
\hline Status & $\sqrt{ }$ & & - \\
\hline
\end{tabular}

Source: Reed (2009)

Note: A tick indicates that the particular characteristic was proven statistically meaningful. 


\section{VALUERS' NEEDS ASSESSMENT}

A nationwide survey was done among valuers and property agents specialising in farm valuations. The goal was to collect information to provide guidelines for the design of a farm valuation support system that will enable the valuer to compare a subject farm with transaction farms with respect to relevant value bearing attributes.

\subsection{Status, gender, age and locality of the valuers in the sample}

Of all the questionnaires ${ }^{6}$ that were distributed, 96 questionnaires were completed and successfully retrieved. Professional and associate valuers were the largest component of the sample (40 each) and of the 40 professional valuers, 3 of them also served as property agents. The average age of the valuers in the sample was 53 and male valuers represented the largest component of the sample as shown in Figure 2.

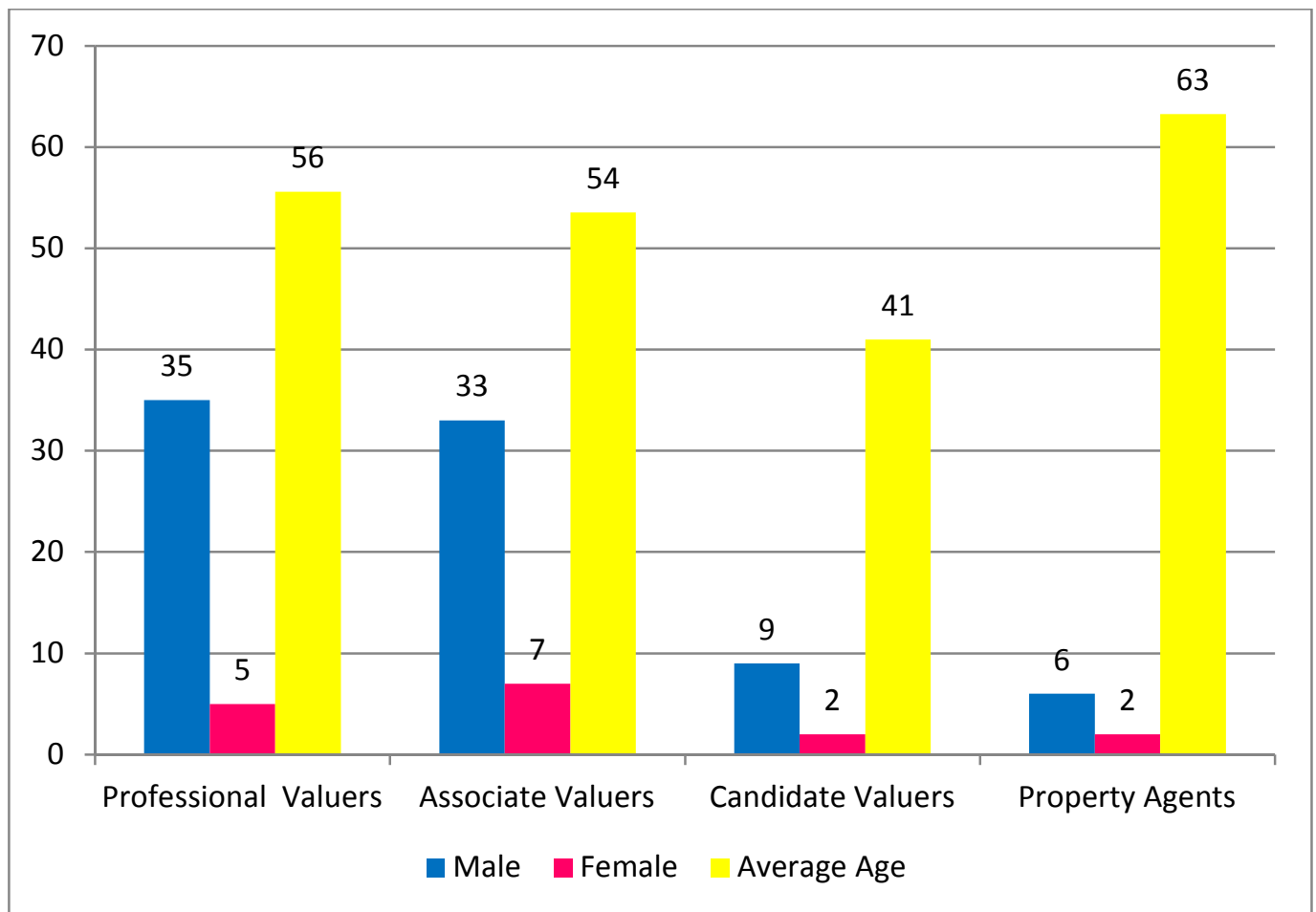

Figure 2: Sex and average age of the respondents of the valuer survey

On 4 November 2009 a workshop on farm valuations, organised by the Southern Branch of the South African Institute of Valuers, were held in Stellenbosch where 29 questionnaires were completed by valuers (no property agents) that attended the

\footnotetext{
${ }^{6}$ The questionnaire is displayed in Appendix A.
} 
workshop that day, the rest (67 questionnaires) were retrieved electronically from valuers and property agents nationwide. The survey therefore shows a bias towards the Western Cape, where most valuers and property agents in the sample tend to live and do most of their valuations, as shown in Table 3. The total number of valuers in the sample that does valuations in a specific province is also shown in Table 3.

Table 3: Province where respondents of the valuer survey live and work

\begin{tabular}{|l|c|c|c|c|c|c|c|c|c|}
\hline PROVINCE & WC & EC & KZN & FS & GP & LP & MP & NC & NW \\
\hline LIVE & 48 & 8 & 7 & 6 & 15 & 5 & 1 & 3 & 3 \\
\hline $\begin{array}{l}\text { VALUATIONS } \\
\text { (MOST) }\end{array}$ & 42 & 9 & 7 & 7 & 6 & 5 & 5 & 4 & 3 \\
\hline $\begin{array}{l}\text { VALUATIONS } \\
\text { (TOTAL) }\end{array}$ & 45 & 11 & 11 & 17 & 11 & 11 & 17 & 9 & 11 \\
\hline
\end{tabular}

\subsection{Valuers' average experience regarding farm property valuation}

Figure 3 shows the average valuation experience of the different categories of valuers in the sample. The average percentage of farm valuations done per annum in the sample population is 38 percent, which means that on average the number of farm valuations that are done per year are relatively lower than non-farm property valuations.

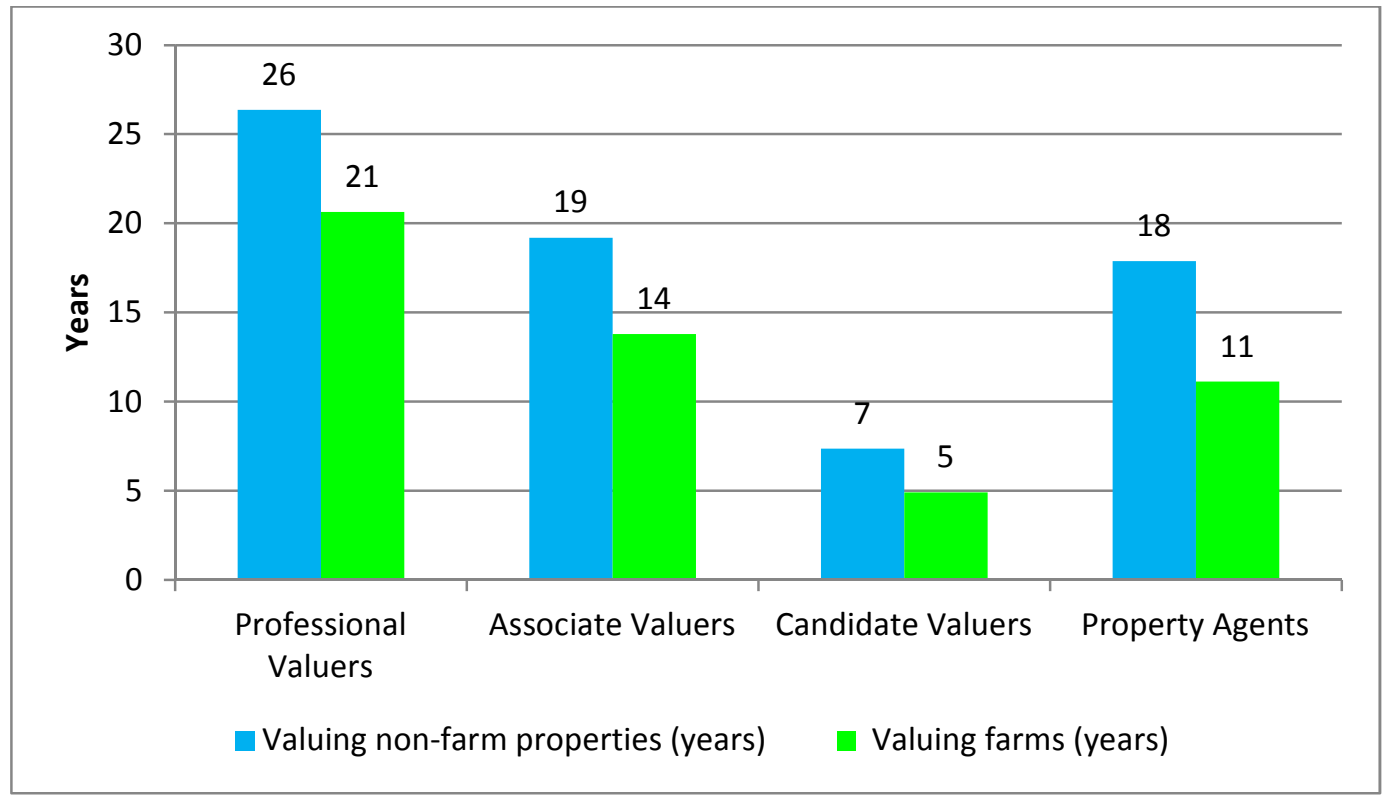

Figure 3: Valuers' average level of experience in valuation of farm and nonfarm properties 


\subsection{Organisations' request for farm valuations}

Bank credit is largely based on the capability to pay rather than security, but, because of the National Credit Act the value of the property still plays an important role in the acquisition of a bond. In this context farm valuations are essential and therefore commercial banks make more use of specialist businesses that have professional valuers available, Figure 4 is evidence thereof.

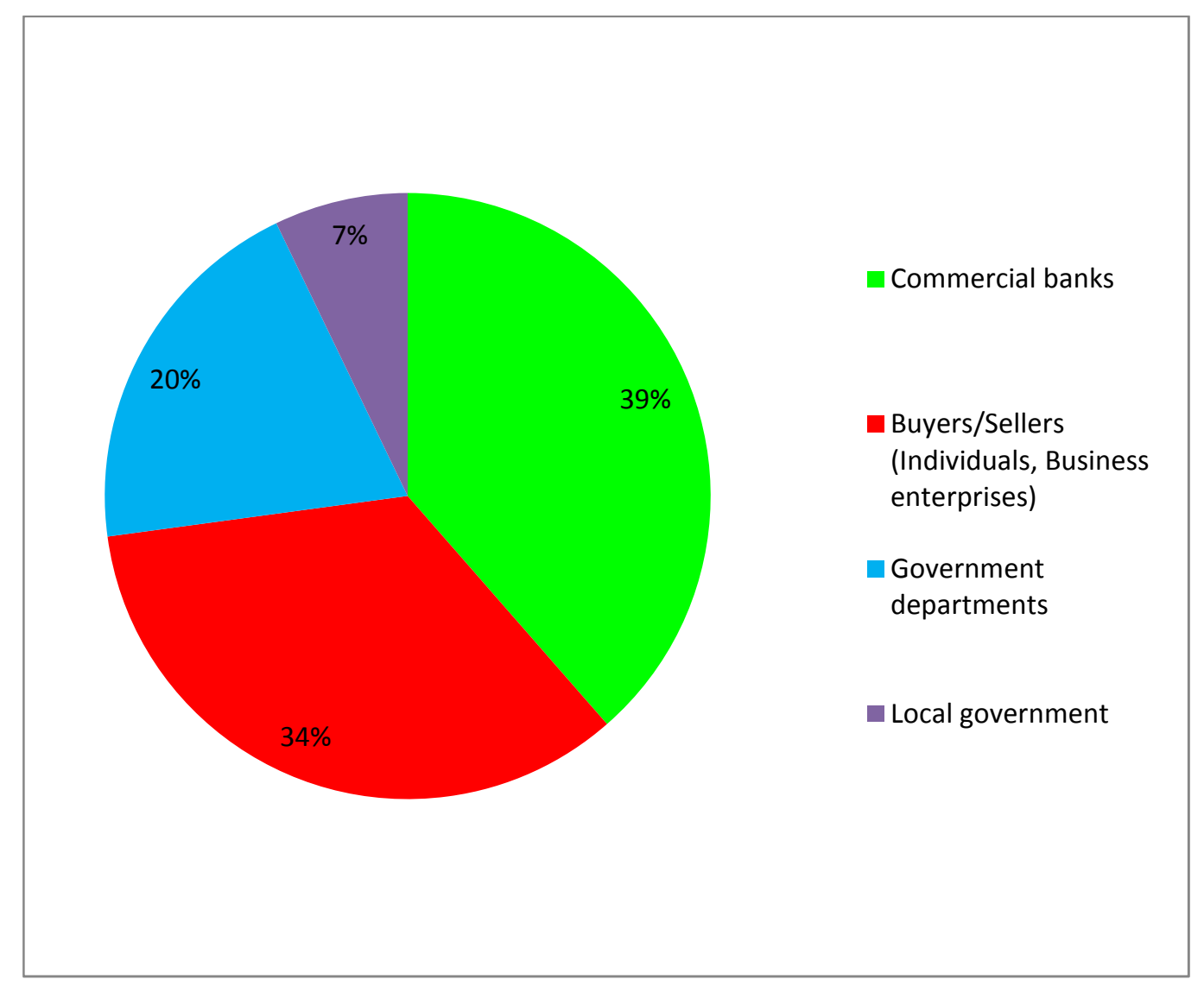

Figure 4: Organisations' request for farm valuations

\subsection{Indication of the need for a farm valuation support system and the benefits thereof}

Figure 5 shows that $31(79 \%)$ professional valuers, $18(45 \%)$ associate valuers, 4 $(36 \%)$ candidate valuers and $3(38 \%)$ property agents in the sample uses Winxfer or Lightstone to find farms or smallholdings. 


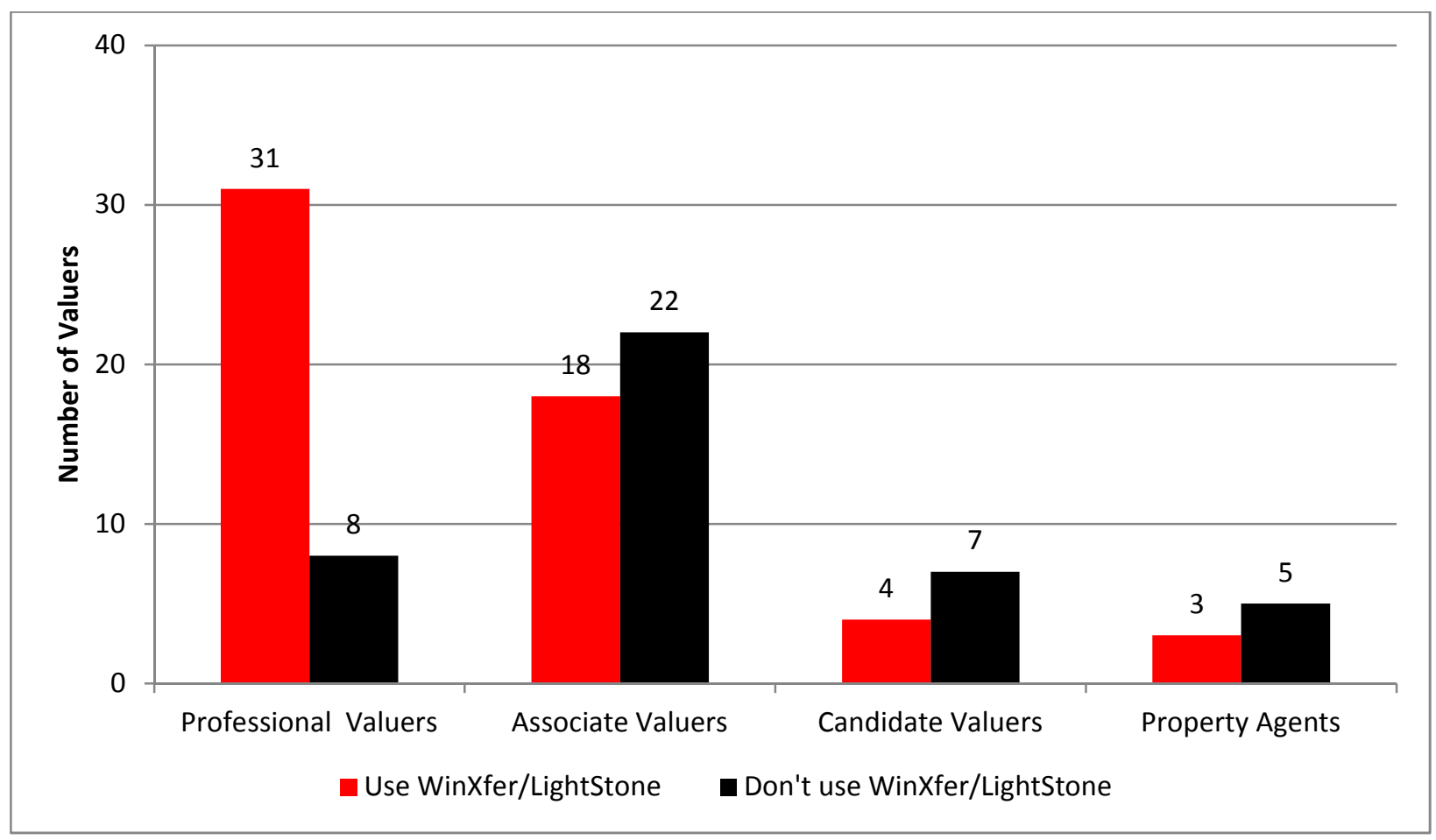

Figure 5: Valuers using Winxfer or Lightstone to find farms or smallholdings

A valuer spends on average two hours to locate a subject property and transaction properties on a paper map. The valuer that uses WinXfer or Lightstone potentially saves 0.71 hours $(\approx 43$ minutes) while trying to locate a subject property and transaction properties and potentially retrieves an additional 3.40 districts' monthly reports on average per month. Valuers therefore benefit by using WinXfer or Lightstone and this demonstrates that the need for a farm valuation support system does exist and that it will be used by valuers.

\subsection{Valuers' preference regarding the 'cleaning' of properties}

Two options were presented to valuers in the questionnaire:

\section{Option A}

Would you prefer to identify potentially comparable properties via WinXfer/Lightstone and 'clean' them in order to compile a shortlist of properties, PRIOR to determining their location with the proposed valuation support system?

\section{Option B}

Would you prefer to get all transaction properties over a predetermined period automatically on the map of the proposed valuation support system linked to WinXfer/Lightstone, in order to 'clean' them afterwards? 
The result:

30 Valuers chose Option A and 34 valuers chose Option B.

The motivation of the valuers who prefer Option B was expressed during the workshop. They were afraid that they may exclude a potentially good comparable transaction during the cleaning prior to the mapping.

\subsection{An indication of valuers' computer connection preference and GIS skills}

Most valuers in the sample make use of ADSL (74\%), while 43 percent indicated that they make use of a modem and 39 percent has a computer network connection. Valuers in the sample tend to have limited GIS skills as shown in Table 4.

\section{Table 4: Valuers' average self-rated computer skills}

\begin{tabular}{|c|c|}
\hline SKILLS & RATING \\
\hline WORD & 3.16 \\
\hline EXCEL & 3.05 \\
\hline IMAP & 2.55 \\
\hline GOOGLE & 2.90 \\
\hline GIS & 2.44 \\
\hline
\end{tabular}

Note: Rating 1 = No skills; Rating 2 = Limited skills; Rating 3 = Quite skilled; Rating 4 = Highly skilled

\subsection{Valuers' importance-rating of available spatial data sets to compare the subject property with transaction properties}

In the questionnaire valuers were asked to rate 19 factors according to their impact on farmland value. The proximity of subject and transaction properties to railroads was the only factor that scored lower than 2.5, the rest were all considered as important factors affecting farmland value. Figure 6 shows the result. 


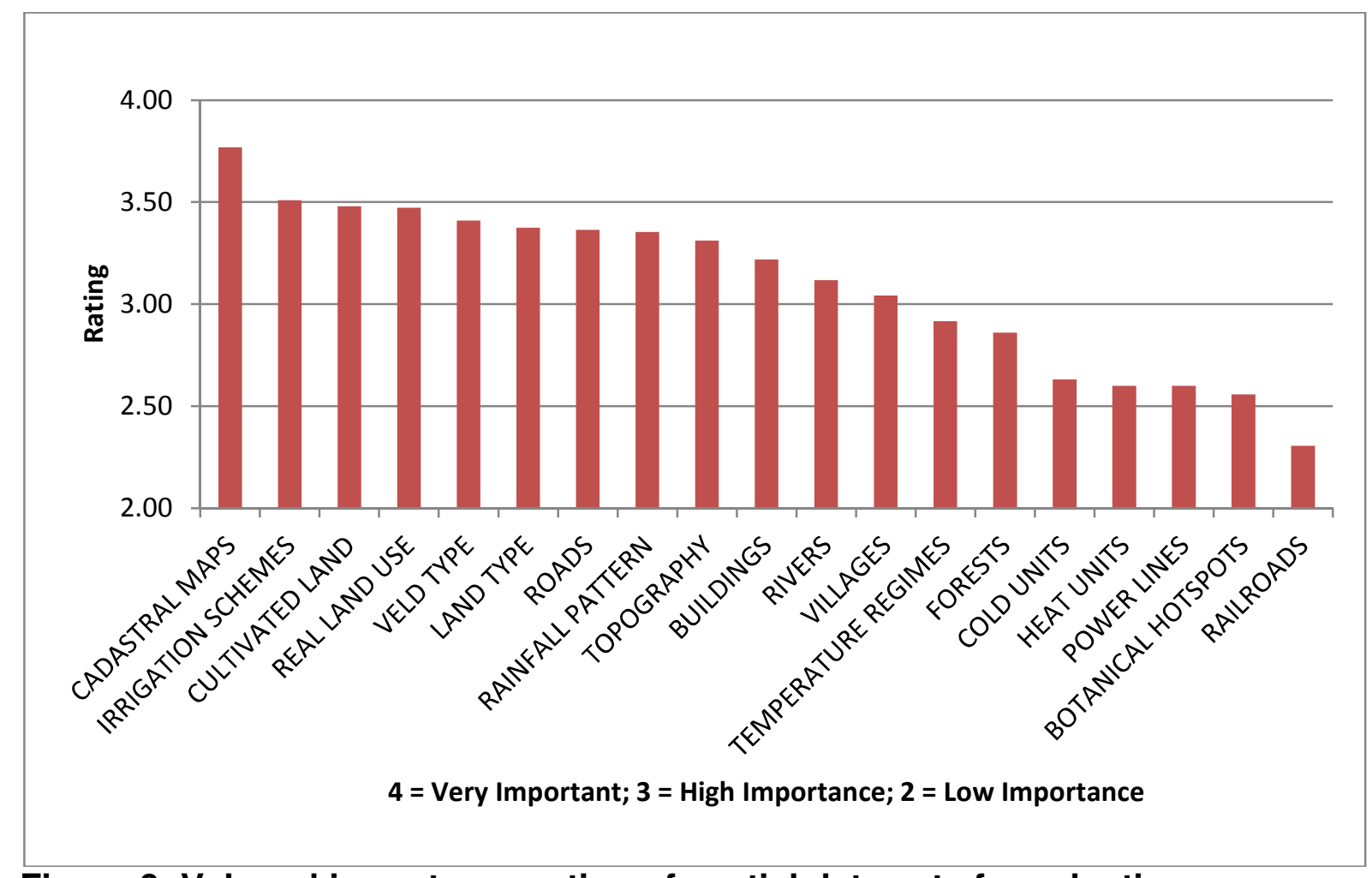

Figure 6: Valuers' importance-rating of spatial data sets for valuation purposes

\subsection{Conclusion}

The information collected through the survey provided guidelines for the design of a farm valuation support system (FVSS) that enables the valuer to compare a subject farm with transaction farms based on relevant value bearing attributes. This survey also demonstrated that the need for a farm valuation support system does exist and that it will be used by valuers. The next chapter focuses on the use of geographic information systems (GIS) in existing property valuation software. 


\section{INCORPORATION OF GEOGRAPHIC INFORMATION SYSTEMS (GIS) IN THE VALUATION PROCESS}

"A geographic information system (GIS) is a computer system for capturing, storing, querying, analyzing, and displaying geospatial data. The ability of a GIS to handle and process geospatial data distinguishes GIS from other information systems. From its beginnings, GIS has been important in natural resource management, including land-use planning, natural hazard assessment, wildlife habitat analysis, riparian zone monitoring, and timber management” (Chang, 2008:1-2).

The sophistication of GIS applications in agriculture increased remarkably over the past decade. GIS was primarily used for mapping distributions, such as the location of soil types and farm boundaries. Now, however, GIS's are utilized for advanced types of both analysis and display, such as modeling erosion, crop suitability, and transportation flows. A major goal has been to manage agricultural resources in a sustainable manner or to optimize production. Historically agricultural scientists employed management or crop models that were non-spatial in nature. More recently, over the past 10-15 years, scientists have recognized the benefits of using GIS to support spatial analysis of natural resources, like spatial land suitability models. As the use of GIS become more widespread and digital data exchange and sharing increase, data integration issues are becoming more apparent as users aim to utilize a variety of data sets from different sources. A GIS would help to improve the understanding of the processes of land evaluation and decision-making. It can improve the efficiency of data processing, can help to solve data integration problems and can support spatial analysis (Rossiter, 1996).

\subsection{GIS data implementation and application in agriculture}

In developing a tool to forecast rural property values, numerous data sets are required (Hayles \& Grenfell, 2002). Significant amounts of data are available for agricultural applications, however, all of the data are not situated in one database management system. It is distributed among several organizations and in different formats, scale, resolution and coordinate systems. It is thus important to know the associated organizations that will have the specific information one is looking for. 
The timely availability of reliable geo-referenced soil, climate and water data, integrated with infrastructure, socio-economic, cultural, and other factors are essential to achieve sustainable levels of agricultural production and development. This is the impetus behind a co-operative venture mounted by South Africa's Agricultural Research Council and its National Department of Agriculture. The establishment of the National Coordination Committee for Information Management (NATCCIM) resulted in the formation of a working group on GIS. The National Department of Agriculture (NDA), the Agricultural Research Council (ARC) and the nine Provincial Departments of Agriculture (PDA's) are represented on this committee.

The new venture has set up an Agricultural Information System for South Africa (AGIS), the aim of which is to support effective policy formulation and decisionmaking at all levels. AGIS will encourage the creation of information systems that support several consolidated databases. Users will be able to view or extract information over the Internet from the following components:

- A meta-database that will be populated as various spatial databases are added to the system. This will supply information on what data is available; the definition of each data element; whether data meet specific needs, and how to acquire and extract those data for local use. The software complies with meta-data content standards drafted by the US Federal Geographic Data Committee (FDGC) and links with the National Spatial Data Discovery Facility.

- An orientation database that contains national and provincial boundaries, rural land parcels linked to particular owners, towns and settlements, roads, railways, and scanned 1:50 000 cadastral maps.

- A topographic database that contains digital elevation data together with applications that can be invoked to generate user-defined products such as slope and terrain morphological maps.

- An internet-based climate information system, accessible through an interface that allows the user to define a query for a particular time-series. The query is submitted to a central processing unit for interpolation and the resulting map forwarded to the client. 
- A soil database and information system holding data relating to land types and soil profiles, mineralogical data for input into models, and derived products such as soil patterns, fertility status, and chemical composition.

\subsection{Web-based versus Desktop Spatial Decision Support System (SDSS) for farmland valuations}

Geographic Information Systems (GIS) are moving from isolated, standalone, monolithic, proprietary systems working in client-server architecture to smaller webbased applications and components offering specific geo-processing functionality and transparently exchanging data among them. Interoperability is at the core of this new web services model.

With respect to their IT infrastructure, organizations aim to:

- maximize productivity and efficiency;

- protect critical information; and

- overcome problems related to data sharing, security and data maintenance, as well as software special requirements and steep learning curves.

The Worldwide Web (WWW) offers the potential benefits of flexibility, ubiquity, and reduced costs and risks of obsolescence and isolation. However, when organizations try to use the web as platform to deliver geographic data and provide geo-processing functionality to their end-users, they commonly find that commercial web-GIS software raises the following issues:

- it does not currently offer out of the box geo-processing functionality to perform many of the analyses demanded by their end users;

- it is expensive;

- it has a steep learning curve;

- it requires that some of their IT personnel become specialists in the software operation and maintenance; and

- it is difficult to integrate with existing IT infrastructure (personnel skills, software and applications) 
In the article 'Web-based spatial information management systems', Bertolotto et al. (2002) discuss the innovative software solutions offered by e-Spatial technology for the development of web-based and mobile spatial information management systems. The technology has been developed within the Oracle 9i Database environment and allows building and deploying spatially enabled Internet applications on any Oracle supported hardware platform and on any device running a Java Virtual Machine (e.g., standard web browsers, PDA's and other mobile devices). The paper focuses on a Land Information Management System (LIMS) application developed for the Irish Department of Agriculture. The application utilizes the e-Spatial Information Server to deliver a spatially enabled Internet solution for the tracking and management of land information based on land usage, land classifications and land ownership changes over time. The developed land information management system provides a seamless Oracle 9i Spatial database environment for the combination of multiple land information data sets. The normal edit (e.g. create, modify, and delete) and spatial analysis functions associated with traditional GIS based land management applications are deployed as Java stored procedures in the Oracle Spatial database.

The LIMS application, developed for the Irish Department of Agriculture, is a webbased spatial information system that serves 125000 farmers in the territory of the Republic of Ireland. A functional overview is provided in the following.

The functionality provided by LIMS system includes:

- View farmers' details online

- Locate a parcel/area using different criteria

- Digitizing

- Spatial queries

- Printing

Accessing the system requires all users to logon with a valid name and password. Different security restrictions are applied to different groups of users (e.g., only viewing/querying, viewing and editing). 
The internet provides the most efficient way to distribute information. Compared with PC-based Decision Support Systems (DSS), web-based DSS has several advantages:

- Update of web-based systems and information is much faster. This is particularly important for some applications that are based on real-time information, such as severe weather forecast.

- Web-based DSS usually provides the widest access to many users simultaneously.

- Most web-based DSS only need a browser to access a DSS, which is important for many non-professional users.

- Most web-based applications have friendly interfaces for non-professional users.

\subsection{The Potential of WebGIS}

Much recent attention has focused on developing GIS functionality in the Internet, Worldwide Web and private intranets and is sometimes termed WebGIS. WebGIS holds the potential to make distributed geographic information (DGI) available to a worldwide audience. Internet users will be able to access GIS applications from their browsers without purchasing proprietary GIS software. WebGIS will also make it possible to add GIS functionality to a wide range of network-based applications in business, government and education. Many of these applications will be run on intranets within businesses and government agencies as a means of distributing and using geospatial data. Many experiments are now underway in WebGIS and related map-server applications for interactive cartography. One of the important areas of innovation involves "pay-for-use" mapping and GIS services.

The challenge of WebGIS lies in creating software systems that are platform independent and run on open TCP/IP-based networks that are on any computer capable of connecting to the Internet (or any TCP/IP-based network) and able to run a Web browser. This task is different from running proprietary GIS software over local-area networks (LANs) or intranets on just a few types of computer hardware. Such systems already exist. 
Many strategies can be employed to add GIS functionality to the Web:

- Server-side strategies allow users (clients) to submit requests for data and analysis to a Web server. The server processes the requests and returns data or a solution to the remote client.

- Client-side strategies allow the users to perform some data manipulation and analysis locally on their own machines.

- Server and client processes can be combined in hybrid strategies that optimize performance and meet special user needs.

Developers can program their applications from scratch or now, more commonly, purchase the necessary GIS modules from commercial vendors.

The visual design of the WebGIS interface-though not discussed in this studyrequires great care to assure that users can understand and make use of the information and functions provided by the system.

\subsection{Property valuation software}

Already existing property valuation software namely: SAPTG (South African Property Transfer Guide), Deedsweb (Windeed and Aktex) and Lightstone are well known amongst South African valuers and will be discussed in this section.

\subsubsection{SAPTG (SA property transfer guide)}

Property Transfer: Records of property transfer (mostly residential properties), since 1993, as recorded at the Deeds office. Data includes buyer and seller names, purchase price, date of transfer, plot number, address (where available) and mortgage holder.

Computer Assisted Valuation: Property specific search based on a physical street address, plot number or sectional scheme name of a property. Geographical location is represented on a map as well as the location of the most recent property transfers in the immediate vicinity. Summary information, such as the number and total value of properties transferred, as well as the highest, lowest 
and average value of properties in the street and suburb are displayed. This report is ideal to include in a CMA report to the client.

Price Bands: Price Bands offers a summary view of the transactions at both a price band and monthly level within a suburb or town for a specified period (limited to a maximum of 6 months per report). Fifteen price bands (price ranges) have been predetermined to give members a comprehensive view of the pricing profile of the different suburbs.

Suburb Trends: Suburb Trends allow the valuer to present accurately established statistics of growth per suburb at the click of a button. The underlying data has been "cleaned" of outliers as well as other anomalies which would ordinarily distort the averages and medians. Median prices are established for the suburb with the 1,3 and 5 year growth percentages being based on the growth of the median price.

SAPTG's AVM Report:

Property information such as location, ownership, transfer history and predicted value. 


\begin{tabular}{|c|c|c|c|c|c|c|c|c|c|}
\hline \multicolumn{10}{|c|}{ PROPERTY DETAILS: } \\
\hline \multicolumn{2}{|c|}{ Property Type: } & \multicolumn{4}{|c|}{ Erf / Full Title } & & & & \\
\hline \multicolumn{2}{|c|}{ Erf Number / Portion: } & \multicolumn{4}{|c|}{$46086 / 0$} & \multicolumn{4}{|c|}{ Automated Valuation } \\
\hline \multicolumn{2}{|c|}{ Land Size: } & \multicolumn{4}{|c|}{$698 \mathrm{~m}^{2}$} & \multicolumn{2}{|c|}{ Predicted Value: } & \\
\hline \multicolumn{2}{|c|}{ Suburb: } & \multirow{2}{*}{\multicolumn{4}{|c|}{ RONDEBOSCH }} & & igh Value: & \multicolumn{2}{|c|}{ R 2866375,00} \\
\hline \multirow{2}{*}{\multicolumn{2}{|c|}{ Current Owners: }} & & & & & & ow Value: & \multicolumn{2}{|c|}{ R 2118625,00} \\
\hline & & \multicolumn{4}{|c|}{ (1) CUNLIFFE LAETITIA 5501290027087} & Con & fidence: & & \\
\hline \multicolumn{2}{|c|}{ Bonds: } & \multicolumn{4}{|c|}{ (1) $\mathrm{R} 0,002009 / 05 / 26$} & \multicolumn{2}{|c|}{$\begin{array}{l}\text { Safety: } \\
\text { Volume: }\end{array}$} & \multicolumn{2}{|c|}{72} \\
\hline \multicolumn{10}{|c|}{ Property Transfers: } \\
\hline Sale Date & Transfer Date & $\mathrm{m}^{2}$ & Price & $\mathrm{R} / \mathrm{m}^{2}$ & Seller & Seller ID & Buyer & Buyer ID & $\begin{array}{c}\text { Title Deed } \\
\text { Number }\end{array}$ \\
\hline $2003 / 06 / 08$ & $2003 / 10 / 03$ & 698 & R 740000,00 & R 1060,00 & $\begin{array}{l}\text { HINRICHSEN } \\
\text { IVOR DALGLISH }\end{array}$ & 3703315020087 & $\begin{array}{l}\text { KOCK IAN } \\
\text { TERTIUS DE }\end{array}$ & 5909215045086 & T93576/2003 \\
\hline $2009 / 04 / 07$ & $2009 / 05 / 26$ & 698 & R 2440000,00 & R 3495,00 & $\begin{array}{l}\text { KOCK IAN } \\
\text { TERTIUS DE }\end{array}$ & 5909215045086 & $\begin{array}{l}\text { CUNLIFFE } \\
\text { LAETITIA }\end{array}$ & 5501290027087 & T23475/2009 \\
\hline
\end{tabular}

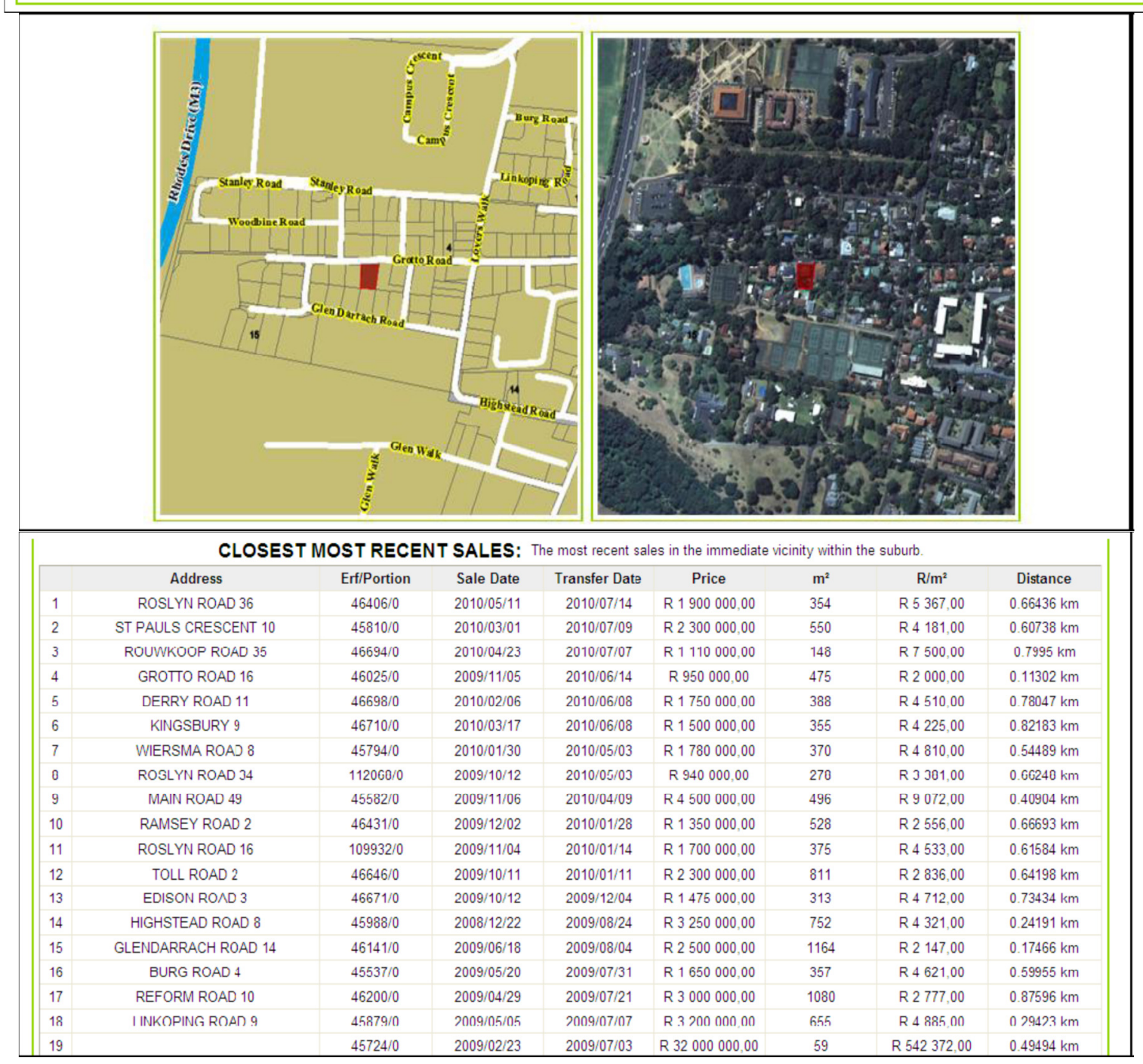

Figure 7: SAPTG'S AVM Report containing valuable residential property information 


\subsubsection{Deedsweb}

DeedsWeb is a true web-enabled deeds information system, which means that clients do not have to buy any software to access information from the Deeds Office. The current interfaces (Windeed and Aktex) will continue as is, which will afford clients a choice of access to their information. All clients need is an Internet connection and Internet Explorer 5.

\subsubsection{Lightstone}

Lightstone are the leading provider of automated valuation technology in the South African mortgage environment and are able to provide comprehensive national coverage. Lightstone provides a range of tools and services that support the municipal valuation environment, ranging from batch valuations to roll management systems. Lightstone's batch valuations have been used for budgeting and auditing purposes and are available nationally. Their roll management systems are also available nationally. A number of municipalities have successfully utilised their services. Listed below are the products and services that they offer:

Information Toolkit - this is a subscription fee of R250 for a branch or a maximum of four users, and it allows users to access an unlimited number of nationwide reports:

- Lightstone Transfer and Bond Report - Transfer and bond activity for the requested suburb, street or specific selection

- Lightstone Suburb Report - Map showing the suburb boundaries, property stock analysis, transaction activity (new or repeat sales), bond activity, types of property (freehold, sectional title or freehold estate), price bands, five year suburb trend analysis (average price, sales, market value and growth, annual inflation).

- Lightstone Property Report - Individual property description, aerial photography, cadastral map, comparable sales and five year suburb trends

Valuable additional products and services that they offer - all charged out at 'pay per click' fees: 
- Lightstone Valuation Report - One of their flagship products is a comprehensive, real time, automated valuation report for individual assessment of properties. This is very useful to assist a valuer when discussing valuations with objectors, the Valuation Appeal Board and/or other valuers. The report includes:

- Property details - title deed number and details, street address details, lat/long coordinates

- Owner Details

- Valuation Details - last sales date and sales price, estimated value, expected high and low, safety and accuracy score

- Municipal Valuation details - assessed rates value and date of rates valuation, zoning and usage of property

- Aerial/satellite image showing the property and the 15 most recent comparable sales

- A table showing the details of the 15 most recent comparable sales and offers to purchase in the area

- Graphs showing suburb price and volume trends

- Three previous transfers on the property

- List of closest amenities

- Bond information - institution, bond amount, bond holder

- R45 per report

Live Deeds Searches - name, property and document search

- Live Deeds Search: R6.00 per search

- Deeds Office Document Retrieval: R7.50 per page

ITC Searches - R29.00 per search

SG diagrams - R2.00 per search

It is quick and easy to set up an account with them, all their services are web based and accessed via their site www.lightstone.co.za, if valuers are interested in subscribing they will just need user names and email addresses to activate company and user accounts. 


\section{Property Report:}

The Property Report is a 'light' version of the Valuation report. It is a comprehensive report that helps agents, buyers and sellers to establish the fair value of a property. It does not include the statistically generated estimation of value provided in the Valuation Report. The Property Report contains the following elements (where available):

- Property details

- Title deed number

- Erf/unit details (as per the South African Deeds Registry)

- Street address details

- Erf/unit size

- Lat/long coordinates

Owner details (as per the South African Deeds Registry)

Valuation details

- Last sales date and last sales price

Municipal valuation details

- Assessed rates value and date of rates valuation

- Zoning/usage of property

Aerial/satellite image showing the property and the 15 most recent comparable sales

A table showing the details of the 15 most recent comparable sales Graphs showing suburb price and volume trends 


\section{Property Report}

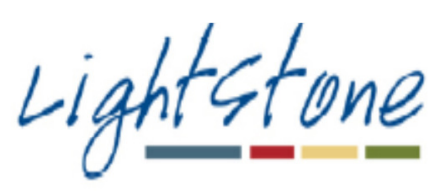

\begin{tabular}{|ll|}
\hline Report Detalls & \\
\hline Report Date: & 2008 108/27 \\
Tracking \#: & Consumer:20080827053014 \\
Repor: $\#:$ & 332839 \\
User: & \\
\hline
\end{tabular}

\begin{tabular}{|c|c|c|c|}
\hline \multicolumn{4}{|c|}{ Property Detalls: } \\
\hline Property Type: & FREEHOLD & GPS Coords: & LAT: 28.0256 LONG: -26.1645 \\
\hline Province: & GAUTENG & Municlpalty & CITY OF JOHANNESBURG \\
\hline Townshlp: & PARIVIEW & Ert: & 444 \\
\hline Portion: & 0 & & \\
\hline Suburt: & PARKVIEW & Street: & GALWAY ROAD \\
\hline Street Number: & 76 & Land Size & 1360 \\
\hline
\end{tabular}

\begin{tabular}{|c|c|c|c|}
\hline \multicolumn{4}{|c|}{ Owner Detalls } \\
\hline Owner Name: & USER WEB & Owner $I D /$ Reg Number. & 58000000000000 \\
\hline
\end{tabular}

\begin{tabular}{|c|c|c|c|}
\hline \multicolumn{4}{|c|}{ Municipal Valuation: } \\
\hline $\begin{array}{l}\text { Valuation: } \\
\text { Zoningrusage: }\end{array}$ & $\begin{array}{l}\text { COMING SOCN } \\
\text { COMING SOON }\end{array}$ & Year of Valuation: & COMNG SOON \\
\hline
\end{tabular}

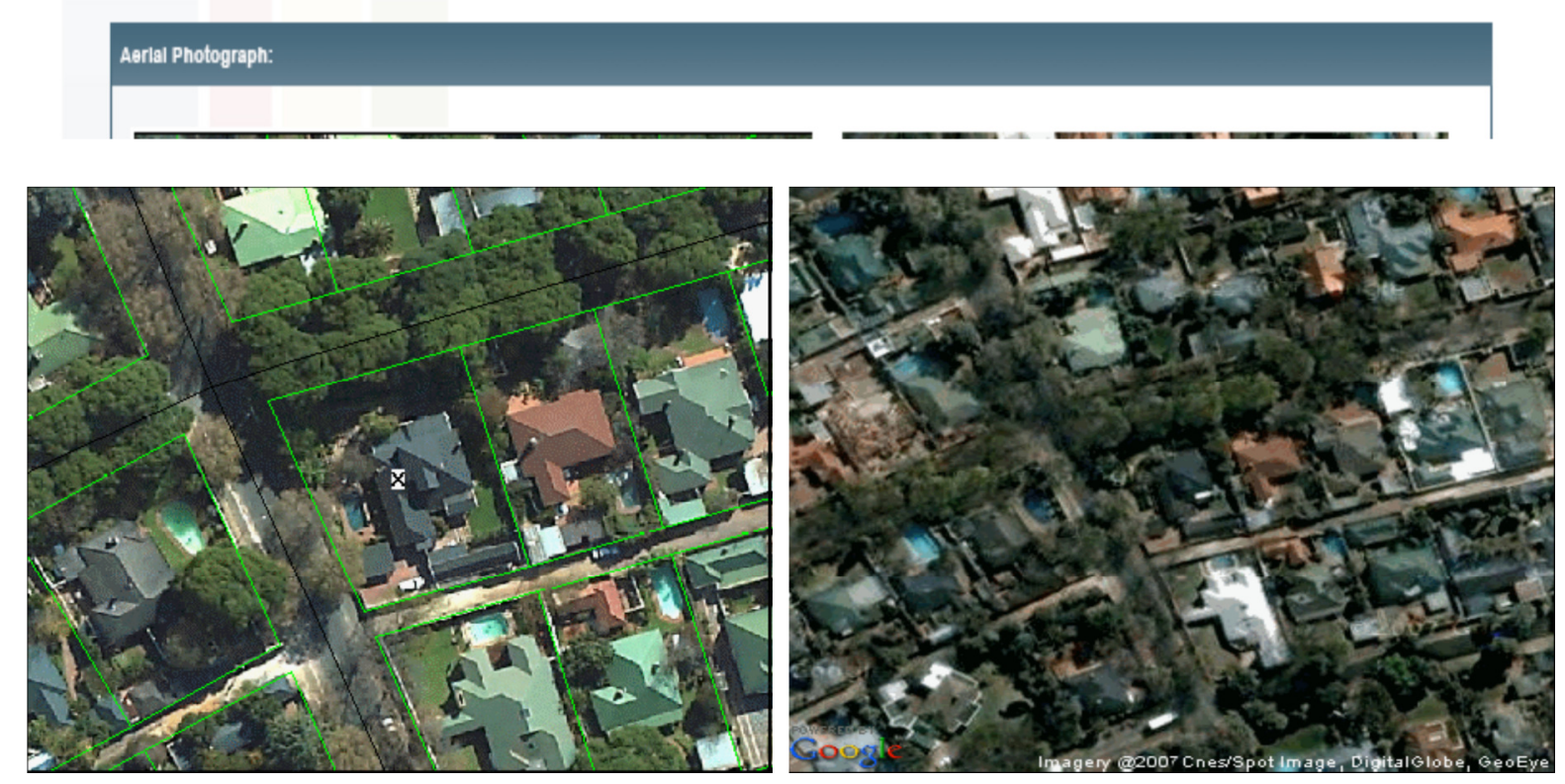

Figure 8: Property details and aerial photograph included in Lightstone's property report 
Comparable sales:

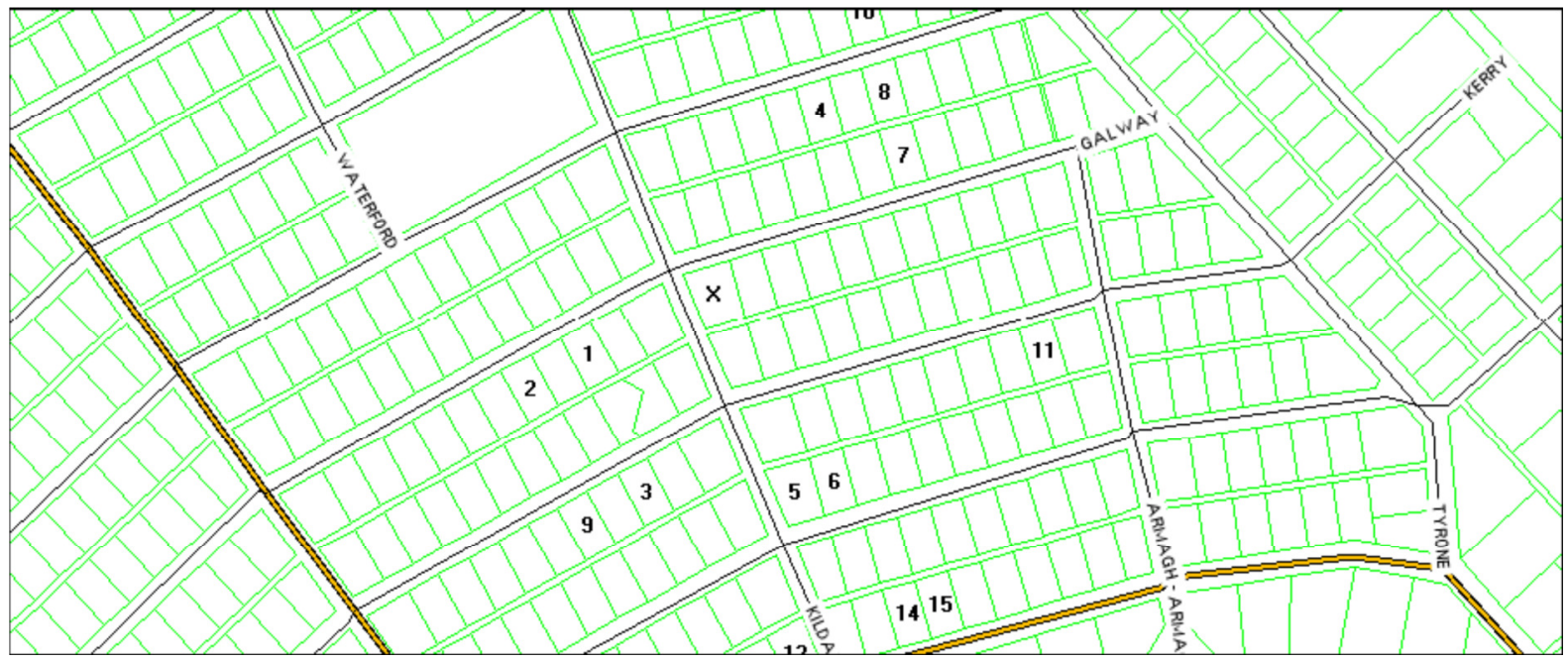

\begin{tabular}{|c|c|c|c|c|c|c|c|c|}
\hline$\#$ & Suburb & Erf & Portion & Sales Date & Transfer Date & Sales Price & Size (m2) & Distance \\
\hline 1 & PARKVIEW & 745 & 0 & 20071007 & 20080205 & 2100000 & 1020 & 99 \\
\hline 2 & PARKVIEW & 747 & 0 & 20070508 & 20070709 & 4000000 & 1020 & 148 \\
\hline 3 & PARKVIEW & 769 & 0 & 20070228 & 20070703 & 2900000 & 1020 & 150 \\
\hline 4 & PARKVIEW & 411 & 0 & 20070918 & 20071101 & 4700000 & 1020 & 151 \\
\hline 5 & PARKVIEW & 490 & 0 & 20071123 & 20080222 & 2500000 & 1272 & 153 \\
\hline 6 & PARKVIEW & 489 & 0 & 20070219 & 20070627 & 3725000 & 1020 & 159 \\
\hline 7 & PARKVIEW & 423 & 0 & 20070323 & 20070628 & 3925000 & 1020 & 168 \\
\hline 8 & PARKVIEW & 409 & 0 & 20070218 & 20070531 & 3700000 & 1020 & 189 \\
\hline 9 & PARKVIEW & 771 & 0 & 20071115 & 20080229 & 2800000 & 1020 & 189 \\
\hline 10 & PARKVIEW & 396 & 0 & 20080409 & & 2800000 & 1020 & 227 \\
\hline 11 & PARKVIEW & 466 & 0 & 20080303 & 20080516 & 4000000 & 1020 & 238 \\
\hline 12 & PARKVIEW & 799 & 0 & 20080723 & & 2500000 & 1103 & 263 \\
\hline 13 & PARKVIEW & 799 & 0 & 20070628 & 20070906 & 1850000 & 1103 & 263 \\
\hline 14 & PARKVIEW & 523 & 0 & 20080521 & 20080703 & 1900000 & 1020 & 267 \\
\hline 15 & PARKVIEW & 522 & 0 & 20070228 & 20070730 & 2000000 & 1020 & 274 \\
\hline
\end{tabular}

Figure 9: Comparable sale's information included in Lightstone's property report

\subsection{Conclusion}

The above mentioned valuation models are mostly used for residential property valuations and not for farm valuation purposes. They contain no information about resource quality which is precisely the information needed for farm valuations. The next chapter focuses on the development of a farm valuation support system that captures resource quality considerations. 


\section{INCORPORATION OF LAND AND SOIL SUITABILITY INFORMATION}

The qualitative characteristics of soil determine a soil's suitability for crop production or agricultural activity on the property and therefore play a very important part in the valuation process. Land quality is not considered in existing valuation systems that primarily focus on residential property, as could be seen in the previous section. Because land quality is an important characteristic on farms, it will be focused on in this chapter.

"While skilful planning and development of a farm by management and expertise of the farmer is largely responsible for its standard of production the best use of the land is normally limited to what its soil and veld qualities are capable of yielding under prevailing climatic conditions and overall rainfall. Supplementary advantages, such as water from irrigation schemes for instance, introduce variable features to which an appraiser must have regard. The inherent qualities of the various soil and veld types ${ }^{7}$ differ extensively over the length and breadth of South Africa. They can vary considerably within the confines of an environment and from one farm to another within a confined locality and even on a farm itself" (Ellenberger, 1983:91).

\subsection{Land in general}

Land comprises the physical environment (climate, topography, soils, hydrology and vegetation) to the level where it affects the potential for land use (FAO, 1976:9). Soil and terrain are narrower concepts than land. Soil is the unconsolidated inorganic and organic material on the immediate surface of the earth that serves as a natural medium for growth of plants on land. Terrain is the physical character of an area and the spatial structure of it (Van der Watt \& Van Rooyen, 1995:301,441). The variation in soil and terrain are generally the main cause for differences between land mapping units within a local area (FAO, 1976:9).

A land mapping unit is a mapped area of land which share common features. Units are defined and mapped through natural resource surveys and their degree of

\footnotetext{
${ }^{7}$ Veld type: "... a unit of vegetation whose range of variation is small enough to permit the whole of it to have the same farming potentialities" (Acocks, 1988).
} 
homogeneity varies with the scale and intensity of the study (FAO, 1976:9). Land mapping units form the basis for land evaluation (Dent \& Young, 1981:117).

\subsection{Land suitability and capability}

Data containing soil characteristics can be used by soil scientists for agricultural planning and evaluation purposes, but a more general set of criteria is necessary to accomodate valuers during farm valuations. The purpose of land suitability evaluation is to link land mapping units to specific types of land uses. Land suitability refers to the appropriateness of a given type of land for a specified land use and land capability can be seen as the country's inherent ability to perform at a given level of general use (FAO, 1976:9,16).

\subsubsection{Land characteristics and qualities}

A land characteristic is a land attribute that can be measured or estimated, e.g., slope degrees, rainfall, soil texture, etc., land mapping units are in general described in terms of land characteristics. A land characteristic is only important if it has an influence on the inputs required and / or the benefits obtained. Land qualities on the other hand include: yield, moisture accessibility, nutrient accessibility and soil toxicity (FAO, 1976:12-13).

\subsubsection{Requirements and limitations}

The requirements of the land use refer to the set of land qualities that define the production and management conditions of a specified land use (FAO, 1976:14). Constraints can be seen as the extent to which land qualities satisfy land use requirements. Permanent restrictions are those that cannot be changed, it involves slope angle, soil depth, climate, etc., while temporary restrictions can be removed by specific land management practices (Dent \& Young, 1981:129). In many South African soil forms and families, however, the ability of the roots to take up water and nutrition is restricted by a variety of soil properties.

The following list mentions only the most important limiting soil properties:

- Crust formation and hardsetting (physically unstable soils)

- Low clay content in upper part of profile 
- Strongly structured and swelling clays

- Dense clay layers in subsoil

- Wetness

- Underlying weathering rock

- Cemented hardpans eg. hard plinthite, dorbank

- Textural stratification and inverse texture gradients

- Coarse fragments in top- and / or subsoils

- Free carbonates and alkalinity

- High acidity and phosphate fixation

- Salt affected soils

\subsubsection{Land improvements}

Land improvements include activities that change the qualities of the land for the better, this makes the land more suitable for a given use and is classified as important (major) or insignificant (minor). A major improvement is a significant and reasonably permanent improvement in the land qualities that influences a given use, it requires a large once off input (e.g. capital) and once applied, managing and improving it is seen as a periodic cost. Examples include irrigation systems, drainage of swamps and the restoration of alkaline soil. A minor improvement has comparable small effects and / or is not permanent, e.g. pest and weed control or field draining ditches. The main criteria rest with the technical and financial capacity of individual farmers or land users to implement the improvements (FAO, 1976:15).

\subsection{The development of a farm valuation support system (FVSS) that incorporates soil characteristics}

A soil's suitability is determined by various soil characteristics and their interactions. These characteristics and interactions are complex information that is difficult to interpret if one is not a soil scientist, therefore, for the purpose of this study it was necessary to formulate an algorithm that produced a more general expression of a soil's suitability. The result of the algorithm is a soil suitability index out of 100 . The formulation of the algorithm was done with the help of soil scientists (Lambrechts \& Ellis, 2010) (Appendix D). This section dissects the formulation of the algorithm and shows its implementation in the proposed FVSS. 


\subsubsection{Soil characteristics and the suitability of a land type}

Soil classification is necessary to characterise and map soils. The distribution of soils was done by using soil classification and the land type concept as described by MacVicar et al. (1974). A land type is defined as a class of land over which the macro climate, the terrain form and the soil pattern each displays a marked degree of uniformity. This uniformity is such that there would be little advantage in defining more uniform landscapes. One land type differs from another in terms of one or more of macro climate, terrain form or soil pattern (MacVicar et al., 1974). Land type data is the only data up to now that is available for the whole country and forms the basis of this study.

Land type data contains soil characteristics that are difficult to grasp if one is not a soil scientist. To interpret soil characteristics properly one needs to know its limitations. Based on experience, the properties of a specific land type can be used to formulate broad guidelines to qualify its degree of limitation. Therefore, quantitative soil properties such as texture, depth and chemical characteristics are often extracted from soil type data to be used in suitability calculations (CeballosSilva \& López-Blanco 2003b; Cools, De Pauw \& Deckers 2002; De la Rosa et al. 2004). Lambrechts and Ellis (2010) created an algorithm, through interpretation and simplification of the land type data, which designates in a single index figure the combined effects of specific soil characteristics.

This index figure is referred to as a Land Type Suitability Index Value (LTSIV). The LTSIV which designates the combined effects of a land type's specific soil characteristics will be the most important component of the FVSS. This incorporation of land type information distinguishes the proposed FVSS from all other existing property valuation systems. Valuers will be able to use the LTSIV to compare a subject property's soil with properties in the same or adjacent district. The next section shows how soil characteristics captured in land type data sets are translated into a LTSIV. 


\subsubsection{Calculating the Land Type Suitability Index Value (LTSIV)}

Each land type is defined by means of terrain factors, climate factors and soil information and consists of a variety of different soil series'. A soil series is the basic unit of soil classification, being a subdivision of a soil form and consisting of soils which are essentially alike in all major profile characteristics. It is normally the lowest category in a formal classification system (Van der Watt \& Van Rooyen, 1995:182). Each soil series within a land type has unique characteristics, as displayed in Appendix $\mathrm{C}^{8}$, and a soil series index value (SSIV) is calculated for each soil series.

Therefore, the LTSIV of a land type is the sum of each of its SSIV's. The SSIV of a specific soil series is calculated by using quantitative properties namely: (1) Soil Series Suitability Rating (SSSR); (2) Effective Soil Depth Rating; and (3) Texture Class Rating. These quantitative properties are weighted in the SSIV calculation according to the percentage area of the land type covered by the specific soil series.

\subsubsection{Soil Series Suitability Rating (SSSR)}

Soil series' as reported in each land type were evaluated by soil scientists in the Western Cape in terms of its suitability for the commercial production of irrigated perennial crops and a suitability rating was given to each soil series. The soil series suitability rating (SSSR) ranges from 1 to 10 , with 1 the lowest and 10 the highest suitability. With the experience and knowledge accumulated over the years by soil scientists in the different production areas of the Western Cape, the SSSR can be seen as a reliable prediction. The ratings can be interpreted according to the guidelines in Table 5 and were used for LTSIV calculation purposes.

Table 5: Interpretation of the soil series suitability rating (SSSR)

\begin{tabular}{|c|c|c|}
\hline $\begin{array}{c}\text { Soil series suitability } \\
\text { rating (SSSR) }\end{array}$ & $\begin{array}{c}\text { General suitability } \\
\text { description }\end{array}$ & $\begin{array}{c}\text { Suitability for perennial } \\
\text { crops }\end{array}$ \\
\hline$\leq 2$ & Very low & Not recommended \\
\hline$>2-\leq 3$ & Low & Marginally recommended \\
\hline$>3-\leq 4$ & Low-medium & $\begin{array}{c}\text { Conditionally } \\
\text { recommended }\end{array}$ \\
\hline$>4-\leq 5$ & Medium & Recommended \\
\hline$>5-\leq 6$ & Medium-high & Highly recommended \\
\hline$>6$ & High &
\end{tabular}

\footnotetext{
${ }^{8}$ Land type $\mathrm{Ca} 6$ is displayed in Appendix $\mathrm{C}$ as an example.
} 


\subsubsection{Effective Soil Depth Rating}

A soil characteristic frequently used in land suitability analysis is effective soil depth or rooting depth (Cools, et al., 2002; Dendgiz, et al., 2003). Effective depth is the limit to where plant roots can penetrate soil material to take up water, air and nutrients and consequently affect soil suitability. The soil scientist divides the soil profile into horizons indicated by the letters A, E, B, and C. A change of colour is usually the most common characteristic distinguishing the surface layer from the subsoil, the surface layer is usually darker. Subsoil is important for crop production and therefore valuers should make sure that this factor is properly weighted in the valuation (Murray, 1969:320,322). Scotney et al. (1987) defined five classes of effective soil depth for South African conditions and a rating was assigned to each class by soil scientists (Table 6). These ratings were used for LTSIV calculation purposes.

Table 6: Effective soil depth classes and ratings

\begin{tabular}{|l|l|l|c|}
\hline \multicolumn{1}{|c|}{$\begin{array}{c}\text { Depth class } \\
\text { symbol }\end{array}$} & \multicolumn{1}{|c|}{ Depth class } & $\begin{array}{c}\text { Depth: Distance } \\
\text { from surface (mm) }\end{array}$ & $\begin{array}{c}\text { Depth class } \\
\text { rating }\end{array}$ \\
\hline$D_{1}$ & Very deep & $>1000$ & 10.0 \\
\hline$D_{2}$ & Deep & $600-1000$ & 7.5 \\
\hline$D_{3}$ & Average depth & $400-600$ & 5.0 \\
\hline$D_{4}$ & Shallow & $250-400$ & 2.5 \\
\hline$D_{5}$ & Very shallow & $<250$ & 1.0 \\
\hline
\end{tabular}

\subsubsection{Texture Class Rating}

Texture is the relative proportion of mineral particles of different sizes occurring in the soil. The method of separating one surface soil texture from another by such generally accepted terms as 'sand', 'clay,' and 'loam' makes interpretation of surface soil texture relatively easy, regardless of where the soil is located (Murray, 1969:298). Table 7 gives the particle sizes of the main soil texture types. 
Table 7: Particle sizes of the main soil texture types

\begin{tabular}{|c|c|}
\hline Texture type & Particle size $(\mathbf{m m})$ \\
\hline Sand & $2.0-0.05$ \\
\hline Silt & $0.05-0.002$ \\
\hline Clay & $<0.002$ \\
\hline
\end{tabular}

Soil texture is generally very well correlated with the physical and chemical properties of soil (Table 8), and therefore it is often used to make land use recommendations. The type of clay mineral, organic matter content and structure also have a major influence. Texture as such is a much more permanent feature as for e.g. the organic matter content of a land. The reason is the extremely slow weathering rate of primary minerals to form sand, silt and clay. In contrast, the structure and organic matter content of a soil can change over relatively short periods. The structure of topsoil for example, changes each time when it is tilled (Foth \& Turk, 1972).

Table 8: Effect of texture class on various soil properties

\begin{tabular}{|l|c|c|c|}
\hline \multirow{2}{*}{\multicolumn{1}{|c|}{ Important soil properties }} & \multicolumn{3}{c|}{ Limitation class } \\
\cline { 2 - 4 } & Sand & Loam & Clay \\
\hline Water storage capacity & High & Medium & Low \\
\hline Water movement & Low & Medium & High \\
\hline Wind or water erosion & High & Medium & Low \\
\hline Power needed for digging or tillage & Low & Medium & High \\
\hline Plant nutrient storage & High & Medium & Low \\
\hline Contaminant movement & High & Medium & Low \\
\hline
\end{tabular}

Soil texture was grouped into three classes and a rating was assigned to each class by soil scientists (Table 9). These ratings were used for LTSIV calculation purposes. 
Table 9: Soil texture classes and ratings

\begin{tabular}{|c|l|c|c|}
\hline $\begin{array}{c}\text { Texture class } \\
\text { symbol }\end{array}$ & Soil Leaching Status & Clay $\%$ & $\begin{array}{c}\text { Texture class } \\
\text { rating }\end{array}$ \\
\hline $\mathrm{T}_{1}$ & Undifferentiated & $15-30$ & 10 \\
\cline { 2 - 3 } & Dystrophic & $10-45$ & \\
\hline $\mathrm{T}_{2}$ & Undifferentiated & $10-15 ; 30-35$ & \multirow{2}{*}{8} \\
\cline { 2 - 3 } & Dystrophic & $45-55$ & 6 \\
\hline $\mathrm{T}_{3}$ & Undifferentiated & $<10 ;>55$ & 6 \\
\hline
\end{tabular}

*Highly leached (acidic) soils

\subsubsection{Depth-Texture Index Value}

The average of a soil series' combined effective soil depth and texture class rating were calculated to produce an index value that is used in the LTSIV algorithm. In the case of texture class $T_{3}$, the effective soil depth rating is divided by two, because of the limitation that extreme clay percentages $(<10 ;>55)$ place on deep soils in terms of water storage capacity and water movement.

5.3.2.5 The LTSIV algorithm

$$
\begin{aligned}
& \operatorname{LTSIV}=\sum_{i=1}^{k} \operatorname{SSIV}_{i} \quad i=1, \ldots, k \\
& \operatorname{SSIV}_{i}=\frac{(\text { Area\% })_{i}}{100} \times \operatorname{SSSR}_{i} \times(D T)_{i} \\
& D T=\frac{\left(D_{p}+T_{q}\right)}{2} \ldots \ldots \ldots . . \text { For } q=T_{1}, T_{2} \quad p=D_{1}, D_{2}, D_{3}, D_{4}, D_{5} ; q=T_{1}, T_{2}, T_{3} \\
& D T=\frac{\left(\frac{D_{p}}{2}+T_{q}\right)}{2} \ldots \ldots \ldots . . . \text { For } q=T_{3}
\end{aligned}
$$

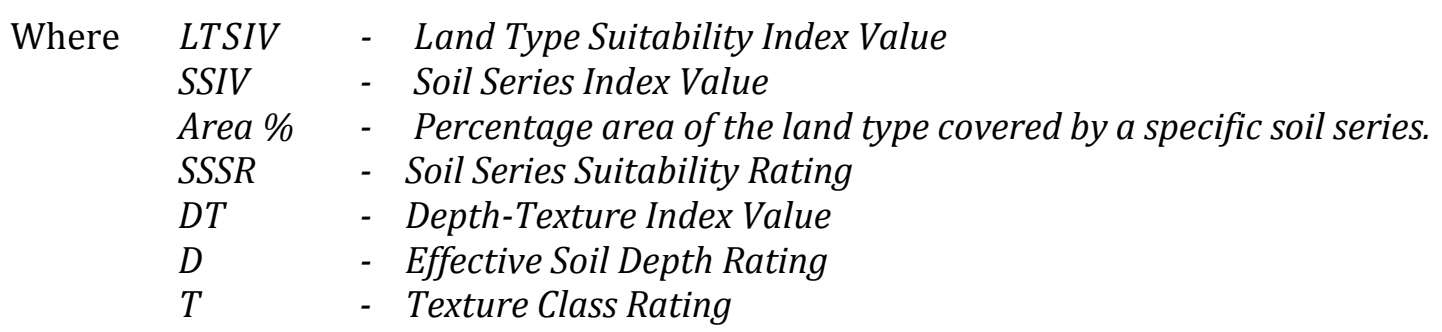

The LTSIV of land type Ab16 is shown in Table 10 as an example. 
Table 10: LTSIV calculation table of land type Ab16 (random selection)

\begin{tabular}{|c|c|c|c|c|c|c|c|c|}
\hline $\begin{array}{l}\text { Soil Series } \\
\text { present in } \\
\text { land type } \\
\text { Ab16 }\end{array}$ & $\begin{array}{c}\% \text { Area of } \\
\text { land type } \\
\text { Ab16 } \\
\text { covered by } \\
\text { soil series }\end{array}$ & $\begin{array}{c}\text { Soil } \\
\text { Series } \\
\text { Suitability } \\
\text { Rating } \\
\text { (SSSR) } \\
\end{array}$ & $\begin{array}{l}\text { Depth } \\
\text { class }\end{array}$ & $\begin{array}{l}\text { Effective } \\
\text { Soil Depth } \\
\text { Rating (D) }\end{array}$ & $\begin{array}{l}\text { Texture } \\
\text { class }\end{array}$ & $\begin{array}{c}\text { Texture } \\
\text { Class } \\
\text { Rating }(\mathrm{T})\end{array}$ & $\begin{array}{l}\text { Depth- } \\
\text { Texture } \\
\text { Index Value } \\
\text { (DT) }\end{array}$ & $\begin{array}{c}\text { Soil Series } \\
\text { Index } \\
\text { Value } \\
\text { (SSIV) }\end{array}$ \\
\hline $\mathrm{R}$ & 9.4 & 1.0 & D5 & 1.0 & T3 & 6 & 3.3 & 0.31 \\
\hline Ms10 & 4.2 & 2.5 & D4 & 2.5 & $\mathrm{~T} 1$ & 10 & 6.3 & 0.66 \\
\hline Cf22Cf32 & 4.3 & 4.8 & D2 & 7.5 & $\mathrm{~T} 1$ & 10 & 8.8 & 1.79 \\
\hline Ms11 & 1.0 & 3.3 & D4 & 2.5 & T2 & 8 & 5.3 & 0.17 \\
\hline Wa21Wa31 & 4.3 & 3.6 & D3 & 5.0 & $\mathrm{~T} 2$ & 8 & 6.5 & 1.01 \\
\hline Gs12Gs15 & 4.3 & 4.9 & D4 & 2.5 & T2 & 8 & 5.3 & 1.10 \\
\hline Hu26Hu27 & 41.6 & 8.0 & D1 & 10.0 & T1 & 10 & 10.0 & 33.28 \\
\hline Vf12Vf15 & 24.4 & 4.3 & D3 & 5.0 & T3 & 6 & 4.3 & 4.41 \\
\hline Du10Oa36 & 4.0 & 5.7 & D1 & 10.0 & $\mathrm{~T} 1$ & 10 & 10.0 & 2.28 \\
\hline We31We32 & 2.4 & 3.6 & D4 & 2.5 & $\mathrm{~T} 1$ & 10 & 6.3 & 0.54 \\
\hline & & & & & & & $\begin{array}{c}\text { Land Type } \\
\text { Suitability } \\
\text { Index } \\
\text { Value } \\
\text { (LTSIV) }\end{array}$ & 45.55 \\
\hline
\end{tabular}

\subsubsection{Comparing five different LTSIV's}

A random sample of five different land types was selected in the Swartland and West Coast regions of the Western Cape as shown in Figure 10. Their respective LTSIV's were calculated in order to compare each land type's soil suitability with one another. The results are shown in Table 11.

\section{Table 11: LTSIV's of the five land types investigated}

\begin{tabular}{|l|l|}
\hline Land type & LTSIV \\
\hline Ab16 & 45.55 \\
\hline Ac481 $^{*}$ & 49.24 \\
\hline Ca38 $^{\star}$ & 21.19 \\
\hline Fb544 $^{\star}$ & 28.25 \\
\hline Ha11 $^{*}$ & 20.19 \\
\hline
\end{tabular}

*See Appendix B for LTSIV calculation tables

From Table 11 one can see that land type Ac481 has the highest soil suitability rating and land type Ha11 has the lowest soil suitability rating of the five land types investigated. 


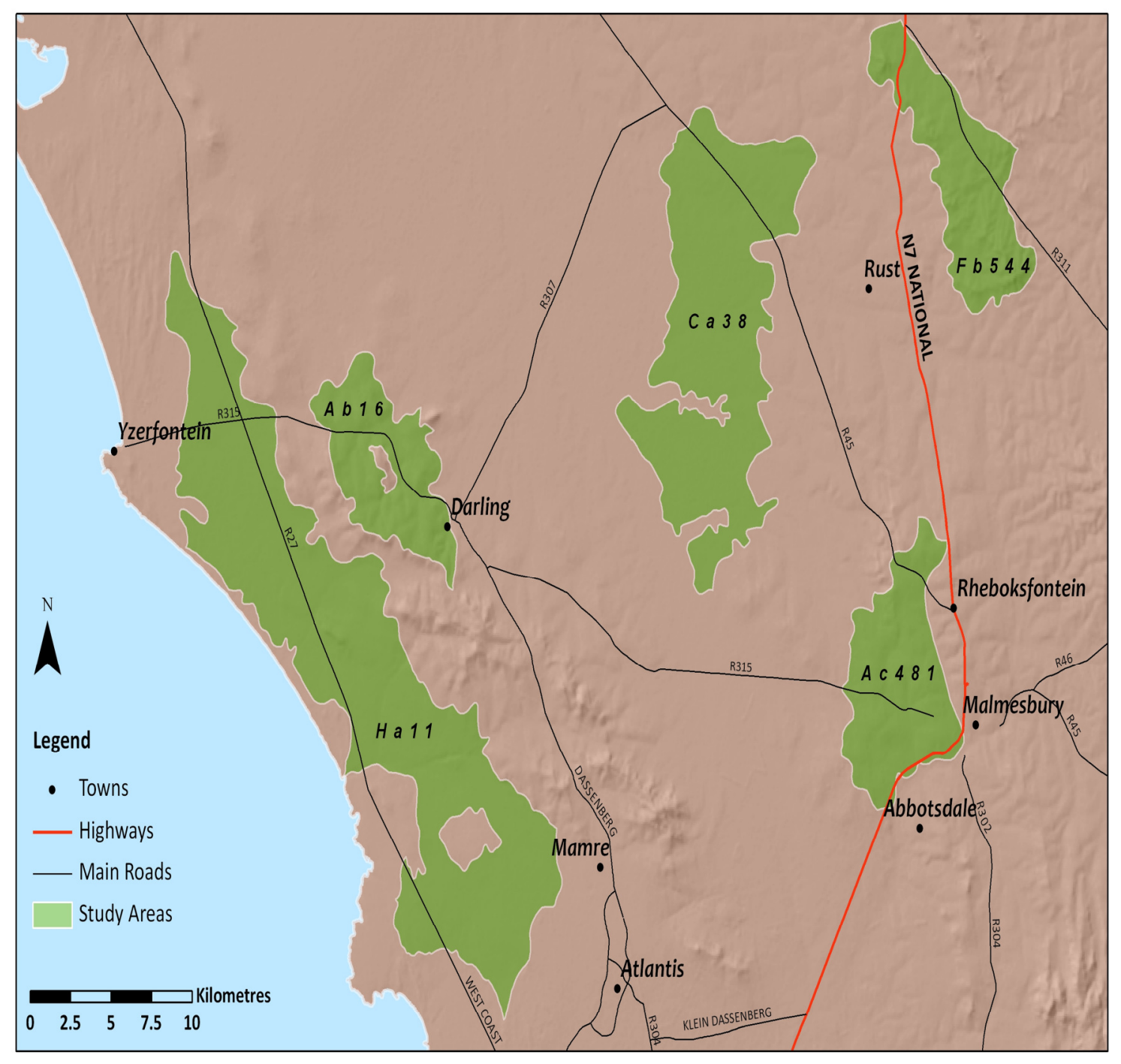

Figure 10: Localities of land type samples

\subsubsection{Valuing a farm property with the help of the proposed FVSS}

To demonstrate how the valuer can use the FVSS to rapidly identify the location of the subject property and transaction properties on an electronic map, a random selection of a subject property (Farm number: $9 / 697$ ) and four transaction properties (Farm numbers: 1 / 551; RE / 463; 4 / 477; 1 / 977) are displayed on the printout of an electronic map (Figure 11). 


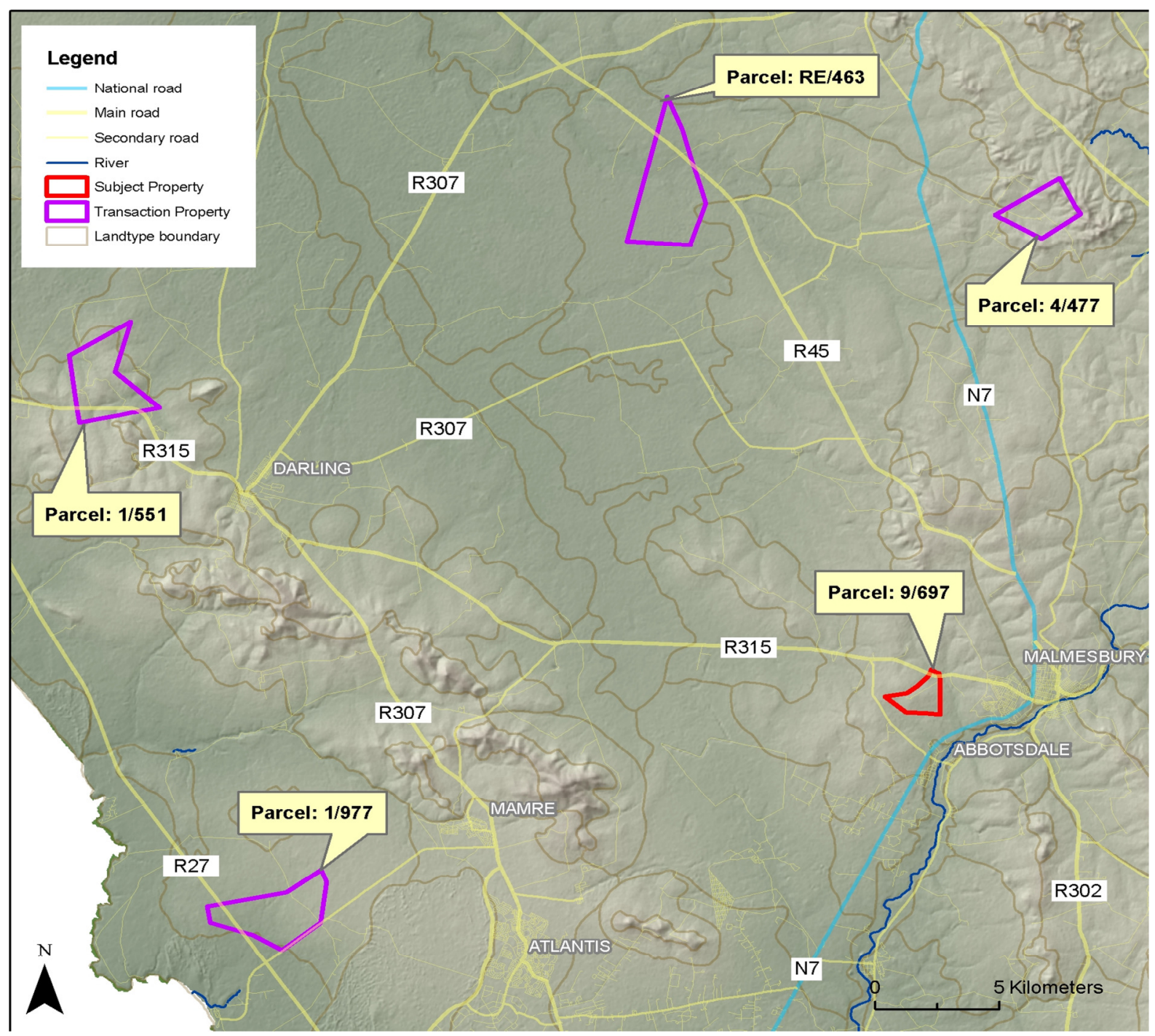

Figure 11: Spatial display of subject and transaction properties on an electronic map

To have a more detailed view of a property and its surroundings, the valuer will be able to zoom in on a specific property. This will enable him/her to view land type boundaries, rivers, roads, the location of buildings on the farm and contour lines indicating the topography of the property. A more detailed view of the subject property $(9 / 697)$ is shown in Figure 12. 


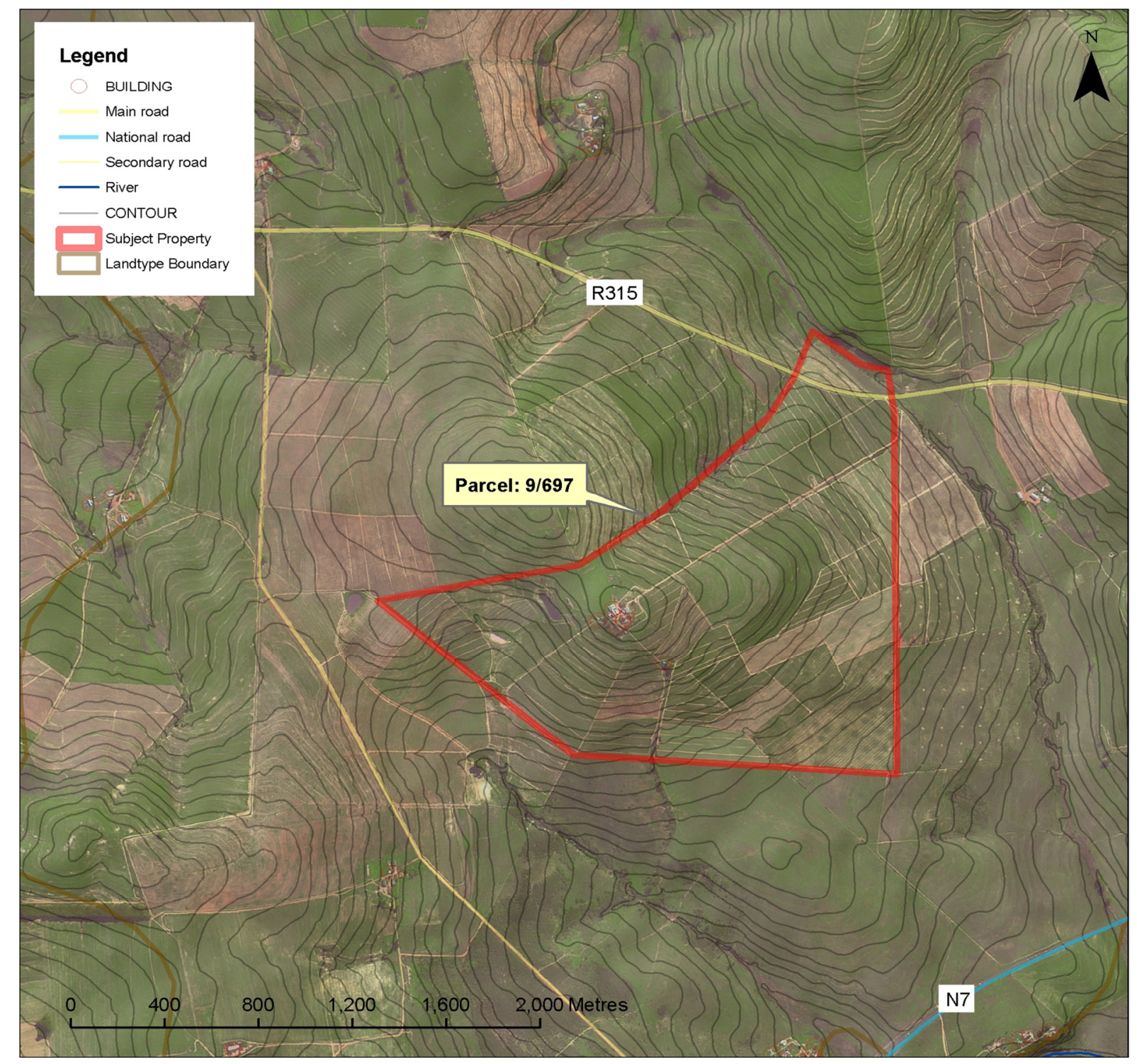

Figure 12: A detailed view of a selected property (subject property: 9 / 697)

In addition to the map the valuer will also be provided with a property information table that contains information about the subject property and each transaction property selected by the valuer. The subject property is compared with transaction properties in terms of the value bearing characteristics of the properties displayed in Table 12. Price, Price per hectare and Price per planted hectare is inserted and completed for the transaction properties to identify patterns regarding the price and value bearing characteristics of the properties. On this basis, the price per hectare and / or price per planted hectare of the subject property are determined. Property prices can be obtained from the Deeds Office records (monthly statements) by the use of WinXfer and / or Windeed. 


\section{Table 12: Subject and transaction property information table}

\begin{tabular}{|c|c|c|c|c|c|}
\hline CHARACTERISTICS & $\begin{array}{l}\text { SUBJECT } \\
\text { PROPERTY }\end{array}$ & $\begin{array}{l}\text { TRANSACTION } \\
\text { PROP. } 1\end{array}$ & $\begin{array}{l}\text { TRANSACTION } \\
\text { PROP. } 2\end{array}$ & $\begin{array}{l}\text { TRANSACTION } \\
\text { PROP. } 3\end{array}$ & $\begin{array}{l}\text { TRANSACTION } \\
\text { PROP. } 4\end{array}$ \\
\hline Portion Number & $9 / 697$ & $1 / 551$ & $\mathrm{RE} / 463$ & $4 / 477$ & $1 / 977$ \\
\hline Extent (hectare) & 232.0 & 816.9 & 1154.4 & 464.6 & 855.6 \\
\hline \multicolumn{6}{|l|}{ Price } \\
\hline \multicolumn{6}{|l|}{ Price / ha } \\
\hline \multicolumn{6}{|l|}{ Price / planted ha } \\
\hline $\begin{array}{l}\text { Land Type } \\
\text { Suitability Index } \\
\text { Value (LTSIV) }\end{array}$ & 50 & 44 & 22 & 30 & 20 \\
\hline $\begin{array}{l}\text { Land Type } \\
\text { Coverage }\end{array}$ & Ac481 (100\%) & $\begin{array}{l}\text { Ab16 }(95 \%), \\
\text { Ca32 (4.5\%), } \\
\text { Db85 (<1\%) }\end{array}$ & $\begin{array}{l}\text { Ca38 (98\%), } \\
\text { Fc737 (1.5\%), } \\
\text { Da15 (<1\%) } \\
\end{array}$ & $\begin{array}{l}\text { Fb544 (97\%), } \\
\text { Fc737 (2.5\%) }\end{array}$ & $\begin{array}{l}\text { Ha11 (99\%), } \\
\text { Ha12 (1\%) }\end{array}$ \\
\hline $\begin{array}{l}\text { Cultivated Area } \\
\text { (percentage of } \\
\text { property) }\end{array}$ & 98 & 100 & 98 & 100 & 0 \\
\hline Buildings & 7 & 18 & 6 & 4 & 0 \\
\hline $\begin{array}{l}\text { Natural Vegetation } \\
\text { Coverage }\end{array}$ & $\begin{array}{l}\text { Swartland } \\
\text { Granite } \\
\text { Renosterveld } \\
(50 \%) \\
\text { and } \\
\text { Swartland } \\
\text { Shale } \\
\text { Renosterveld } \\
(50 \%) \\
\end{array}$ & $\begin{array}{l}\text { Swartland } \\
\text { Granite } \\
\text { Renosterveld }\end{array}$ & $\begin{array}{l}\text { Swartland } \\
\text { Shale } \\
\text { Renosterveld } \\
(50 \%) \\
\text { and } \\
\text { Swartland } \\
\text { Silcrete } \\
\text { Renosterveld } \\
(50 \%) \\
\end{array}$ & $\begin{array}{l}\text { Swartland } \\
\text { Shale } \\
\text { Renosterveld }\end{array}$ & $\begin{array}{l}\text { Atlantis Sand } \\
\text { Fynbos }\end{array}$ \\
\hline $\begin{array}{l}\text { Chill Units } \\
\left(h^{-1}\right)(\text { accumulated } \\
\text { positive chill units } \\
\text { May - Sep) }\end{array}$ & 588.90 & 507.50 & 436.40 & 564.10 & 643.50 \\
\hline Heat Units (annual) & $2,753.90$ & $2,562.80$ & $2,738.40$ & $2,846.60$ & $2,438.80$ \\
\hline $\begin{array}{l}\text { Frost (mean } \\
\text { number of } \\
\text { occurrences of } \\
\text { heavy frost, } \min \\
\text { temp }\left(0^{\circ} \mathrm{C}\right) \text { ) } \\
\end{array}$ & - & - & - & - & - \\
\hline $\begin{array}{l}\text { Mean Annual } \\
\text { Rainfall (mm) }\end{array}$ & 454.00 & 429.00 & 384.80 & 400.50 & 429.00 \\
\hline \multicolumn{6}{|l|}{$\begin{array}{l}\text { Mean Monthly } \\
\text { Rainfall (mm) } \\
\end{array}$} \\
\hline JANUARY & 7.00 & 6.00 & 6.00 & 6.70 & 6.80 \\
\hline FEBRUARY & 6.00 & 5.00 & 5.00 & 5.00 & 6.00 \\
\hline MARCH & 11.00 & 10.50 & 9.00 & 12.00 & 12.80 \\
\hline APRIL & 29.50 & 25.80 & 25.00 & 26.30 & 26.00 \\
\hline MAY & 60.00 & 56.00 & 49.20 & 52.00 & 55.00 \\
\hline JUNE & 70.60 & 66.00 & 60.00 & 62.00 & 69.00 \\
\hline JULY & 67.00 & 67.00 & 56.00 & 57.70 & 68.00 \\
\hline AUGUST & 61.50 & 62.00 & 54.80 & 57.00 & 63.00 \\
\hline SEPTEMBER & 38.00 & 35.00 & 32.00 & 32.50 & 33.00 \\
\hline OCTOBER & 25.00 & 23.40 & 22.80 & 24.00 & 22.60 \\
\hline NOVEMBER & 13.00 & 12.30 & 11.00 & 13.00 & 13.80 \\
\hline DECEMBER & 9.00 & 8.30 & 8.00 & 9.00 & 9.20 \\
\hline $\begin{array}{l}\text { Mean Annual } \\
\text { Temperature }\left({ }^{\circ} \mathrm{C}\right)\end{array}$ & 17.50 & 17.00 & 17.50 & 17.80 & 16.70 \\
\hline
\end{tabular}




\begin{tabular}{|c|c|c|c|c|c|}
\hline \multicolumn{6}{|l|}{$\begin{array}{l}\text { Mean Monthly } \\
\text { Temperature }\left({ }^{\circ} \mathrm{C}\right)\end{array}$} \\
\hline JANUARY & 22.70 & 20.90 & 21.80 & 23.00 & 21.00 \\
\hline FEBRUARY & 23.40 & 21.50 & 22.00 & 23.40 & 21.60 \\
\hline MARCH & 22.00 & 20.40 & 20.80 & 22.00 & 20.30 \\
\hline APRIL & 19.00 & 17.90 & 18.40 & 18.90 & 17.60 \\
\hline MAY & 15.30 & 15.40 & 16.00 & 15.60 & 14.90 \\
\hline JUNE & 13.30 & 13.10 & 13.80 & 13.20 & 12.50 \\
\hline JULY & 12.00 & 12.40 & 12.60 & 12.10 & 11.70 \\
\hline AUGUST & 12.30 & 12.80 & 13.00 & 12.50 & 12.20 \\
\hline SEPTEMBER & 14.00 & 14.40 & 14.70 & 14.30 & 13.90 \\
\hline OCTOBER & 17.00 & 16.60 & 17.10 & 17.10 & 16.10 \\
\hline NOVEMBER & 19.60 & 18.70 & 19.20 & 19.80 & 18.30 \\
\hline DECEMBER & 21.40 & 20.10 & 20.90 & 21.70 & 19.90 \\
\hline \multicolumn{6}{|l|}{$\begin{array}{l}\text { Min Monthly } \\
\text { Temperature }\left({ }^{\circ} \mathrm{C}\right)\end{array}$} \\
\hline JANUARY & 16.00 & 15.30 & 15.30 & 16.10 & 15.10 \\
\hline FEBRUARY & 16.60 & 15.60 & 15.40 & 16.60 & 15.40 \\
\hline MARCH & 15.10 & 14.60 & 14.50 & 15.50 & 14.10 \\
\hline APRIL & 13.10 & 12.20 & 12.90 & 13.30 & 11.60 \\
\hline MAY & 10.20 & 10.30 & 11.30 & 10.90 & 9.40 \\
\hline JUNE & 8.70 & 8.20 & 9.40 & 8.90 & 7.20 \\
\hline JULY & 7.40 & 7.40 & 8.10 & 7.60 & 6.20 \\
\hline AUGUST & 7.30 & 7.80 & 8.20 & 7.60 & 6.60 \\
\hline SEPTEMBER & 8.40 & 9.20 & 9.30 & 8.80 & 8.10 \\
\hline OCTOBER & 10.40 & 10.90 & 11.30 & 10.90 & 10.00 \\
\hline NOVEMBER & 13.00 & 12.90 & 13.00 & 13.20 & 12.40 \\
\hline DECEMBER & 15.00 & 14.50 & 14.60 & 15.10 & 14.20 \\
\hline \multicolumn{6}{|l|}{$\begin{array}{l}\text { Max Monthly } \\
\text { Temperature }\left({ }^{\circ} \mathrm{C}\right)\end{array}$} \\
\hline JANUARY & 30.00 & 26.70 & 28.30 & 29.90 & 27.00 \\
\hline FEBRUARY & 30.40 & 27.30 & 28.50 & 30.10 & 27.80 \\
\hline MARCH & 28.30 & 26.20 & 27.00 & 28.40 & 26.50 \\
\hline APRIL & 25.00 & 23.60 & 23.80 & 24.50 & 23.60 \\
\hline MAY & 20.30 & 20.60 & 20.70 & 20.30 & 20.50 \\
\hline JUNE & 18.00 & 18.00 & 18.10 & 17.50 & 17.80 \\
\hline JULY & 17.00 & 17.30 & 17.20 & 16.70 & 17.10 \\
\hline AUGUST & 17.50 & 17.90 & 17.90 & 17.30 & 17.90 \\
\hline SEPTEMBER & 20.00 & 19.70 & 20.00 & 19.70 & 19.60 \\
\hline OCTOBER & 23.10 & 22.30 & 22.80 & 23.20 & 22.10 \\
\hline NOVEMBER & 26.50 & 24.40 & 25.30 & 26.40 & 24.10 \\
\hline DECEMBER & 28.50 & 25.60 & 27.20 & 28.40 & 25.50 \\
\hline \multicolumn{6}{|l|}{$\begin{array}{l}\text { Proximity to } \\
\text { Nearest: (km) }\end{array}$} \\
\hline Town & 4 & 9 & 13 & 13 & 9 \\
\hline City & 55 & 65 & 73 & 77 & 41 \\
\hline Airport & 54 & 74 & 78 & 76 & 49 \\
\hline Major Road & - & - & - & 3 & - \\
\hline Ocean & 29 & 11 & 31 & 41 & 4 \\
\hline $\begin{array}{l}\text { Grazing Capacity } \\
\text { (ha / Large Stock } \\
\text { Unit) }\end{array}$ & - & 17.83 & 30.18 & 27.07 & - \\
\hline GPS Coordinates & $18.679 ;-33.45$ & $18.315 ;-33.34$ & $18.573 ;-33.242$ & $18.727 ;-33.271$ & $18.408 ;-33.55$ \\
\hline
\end{tabular}




\subsection{Information included in the proposed FVSS database}

The FVSS's main function will be to assist the valuer in comparing the subject property with the transaction properties. Maps are not only timesavers but also an integral part of the valuation process in that they show the farm to be valued in its proper setting with reference to surrounding farms and territory, with visual coverage of the detail.

\subsubsection{Land type coverage, LTSIV, property extent and GPS coordinates}

Land type data with its respective LTSIV information were included in the FVSS. A map showing land type boundaries along with each property's LTSIV will save the valuer much time, as he or she will only need to check the map and property information table while examining the farm. Data that provides the valuer with information about the extent of the farm property in addition to the property's respective Geographic Positioning System (GPS) coordinates were also included and will help to orientate the valuer during the valuation process.

\subsubsection{Climatic data}

\subsubsection{Rainfall}

Rainfall and temperature are considered to be the most important climatic parameters (Ceballos-Silva \& López-Blanco, 2003b; De la Rosa et al., 2004). Rainfall is an essential factor for agricultural land uses, especially for determining the suitability of land for the production of specific crops (Ceballos-Silva \& López-Blanco, 2003a). Rainfall also influences the distribution and occurrence of natural vegetation types. The total amount of rainfall per year as well as rainfall averages per month was included in the data set. "The amount of rainfall during the critical months of the crop season may sometimes be far more significant than the total precipitation figure" (Murray, 1969:337).

\subsubsection{Temperature}

Temperature is frequently used as an index of the energy status in the environment and it affects all forms of life. The occurrence of natural vegetation is strongly related to temperature as all plants have upper and lower temperature limits above or below which their growth development processes cease. 
Three additional temperature-based variables were found to be popular and were considered fundamental to land valuation. The first, heat units (also called growing degree days), is a heuristic index that is used to predict crop maturity or bloom dates (Schulze, 1997). Consequently, heat units are often used to identify areas suitable for crop production (Carey, 2005). A second indicator often used in agricultural applications is chill units (also called positive chill units or chill hours). Chill units are defined as the accumulative number of hours that plants are exposed to temperatures ranging from $2.5^{\circ} \mathrm{C}$ to $9.1^{\circ} \mathrm{C}$ during winter.

The 'Utah' chill unit model of Richardson, Seeley and Walker (1974) was adopted by the South African deciduous fruit industry in the South Western Cape. The model assigns chilling units or portions thereof for each hour at a given temperature with temperatures between $2.5^{\circ} \mathrm{C}$ and $9.1^{\circ} \mathrm{C}$ being the most favorable for chill unit accumulation (Table 13).

Table 13: 'Utah' chill units

\begin{tabular}{|c|c|}
\hline Temperature $\left({ }^{\circ} \mathbf{C}\right)$ & Unit $^{-1}$ \\
\hline$<1.4$ & 0 \\
\hline $1.5-2.4$ & 0.5 \\
\hline $2.5-9.1$ & 1 \\
\hline $9.2-12.4$ & 0.5 \\
\hline $12.5-15.9$ & 0 \\
\hline $16.0-17.9$ & -0.5 \\
\hline$>18$ & -1.0 \\
\hline
\end{tabular}

Source: Richardson et al. (1974)

Chill units is an important factor in land valuation as most deciduous plants require a minimum number of chill units to satisfy dormancy, to stimulate growth, develop leaves, flower and set fruit (Reiger, 2006; Schulze, 1997). Fruit growers and potential buyers of a fruit farm will be interested in such information and will be able to interpret it. Because too low temperatures can be damaging to plants, especially during the growing season, frost data was introduced as a third temperature based variable. 
Frost, chill units, heat units, mean annual temperature, as well as monthly mean, minimum and maximum temperatures were included in the data set. Climatic data is obtained from long-term observations taken at weather stations and because weather stations are relatively sparsely situated, especially so in mountainous regions or areas with low population densities, climatic parameters at any given location are usually determined by interpolating values from the nearest weather station or stations (Ceballos-Silva \& López- Blanco, 2003b).

\subsubsection{Current land cover and use}

The suitability of a parcel of land for a particular land use is affected by its current land cover. The land cover classes considered to be of fundamental importance for valuation purposes are urban areas, agriculture, wetlands, permanent rivers, permanent water bodies and nature conservation areas (Van Niekerk, 2008:67). Natural vegetation coverage, cultivated area (percentage of property) and grazing capacity are important information for farm valuation purposes and were therefore included in the data set.

\subsubsection{Infrastructure attributes}

The availability of existing infrastructure affects the cost and potential to develop land. Many types of infrastructure can be considered in land valuations. These include roads, railways, airports, electricity, dams, irrigation, and storage facilities (Van Niekerk, 2008:67). Roads, buildings and proximity to the nearest town, city, airport, major road and ocean were included in the data set. Roads are probably the most important as they provide access to many of the other types of infrastructure.

\subsubsection{Topography}

Topography deserves a generous share of the valuer's time. It is a key to the water erosion hazard and gives an indication of soil and drainage conditions and often determines the amount of pasture and kind of farming practiced. Soil type is in a way linked to topography and this ease mapping and may also reveal the origin of the soil type. It is desirable to follow a definite and uniform system of measuring topography. The classifications of topography differ for different countries or regions. All can be measured in percentage of slope, but the classification differ (Murray, 1969:327328). Contour line data were included in the data set. 


\subsection{Scale of the data collected for use in the FVSS}

The scale of the published map sets limits on the amount of detail that can be shown and should be decided by the purpose for which it is required (Dent and Young, 1981:88). Lambrechts and Ellis (2010) suggest that scales ranging from 1:2 000000 to 1: 120000 are appropriate for areas as large as the Western Cape. South Africa has standardized on a scale of 1:50 000 for its largest-scale topographical map series covering the Western Cape (CDSM, 2007), and much relevant data is mapped at this scale (van Niekerk, 2008:61). All the data collected for use in the FVSS should therefore preferably be at a scale of 1:50 000 or larger. There are five intensity levels for soil surveys (Dent and Young, 1981:89-92) (Table 14).

Table 14: Scales of soil survey

\begin{tabular}{|c|c|c|c|c|c|c|}
\hline \multirow{2}{*}{$\begin{array}{c}\text { Kind of survey } \\
\text { or map and } \\
\text { level of } \\
\text { intensity }\end{array}$} & \multicolumn{2}{|c|}{ Scales } & \multirow{2}{*}{$\begin{array}{c}\text { Area } \\
\text { represented } \\
\text { by } 1 \mathrm{~cm}^{2} \text { on } \\
\text { map }\end{array}$} & \multirow{2}{*}{$\begin{array}{l}\text { Mean distance } \\
\text { between field } \\
\text { observations } \\
\text { at } 1 \text { per } \mathrm{cm}^{2}\end{array}$} & \multirow[t]{2}{*}{ Mapping units } & \multirow{2}{*}{$\begin{array}{c}\text { Examples of } \\
\text { purposes and } \\
\text { use }\end{array}$} \\
\hline & Range & Typical & & & & \\
\hline $\begin{array}{l}\text { Exploratory } \\
\text { surveys and } \\
\text { compilations } \\
\text { (Level 5) }\end{array}$ & $\begin{array}{c}1: \\
1000 \\
000 \\
\text { and } \\
\text { smaller }\end{array}$ & & $\begin{array}{l}100 \mathrm{~km}^{2} \\
\text { and less }\end{array}$ & - & $\begin{array}{l}\text { Taxonomic soil } \\
\text { classes of high } \\
\text { categories }\end{array}$ & $\begin{array}{l}\text { Display, national } \\
\text { atlases, teaching; } \\
\text { background for } \\
\text { survey } \\
\text { preparation } \\
\end{array}$ \\
\hline $\begin{array}{l}\text { Reconnaissance } \\
\text { (Level 4) }\end{array}$ & $\begin{array}{c}1: \\
500000 \\
\text { to } \\
1: \\
120000\end{array}$ & $\begin{array}{c}1: \\
250 \\
000\end{array}$ & $6.25 \mathrm{~km}^{2}$ & $2.5 \mathrm{~km}$ & $\begin{array}{l}\text { Land systems } \\
\text { or other } \\
\text { landform - soil } \\
\text { units, } \\
\text { combining } \\
\text { great soil } \\
\text { groups }\end{array}$ & $\begin{array}{c}\text { Resource } \\
\text { inventory at } \\
\text { national or } \\
\text { regional levels; } \\
\text { national land use } \\
\text { planning, } \\
\text { tentative project } \\
\text { location }\end{array}$ \\
\hline $\begin{array}{l}\text { Semi-detailed } \\
\text { (Level 3) }\end{array}$ & $\begin{array}{c}1: \\
100000 \\
\text { to } \\
1: \\
30000\end{array}$ & $\begin{array}{c}1: \\
50000\end{array}$ & 25 ha & $500 \mathrm{~m}$ & $\begin{array}{l}\text { Associations, } \\
\text { series; } \\
\text { landform - soil } \\
\text { units combining } \\
\text { associations } \\
\text { and series }\end{array}$ & $\begin{array}{l}\text { Project feasibility } \\
\text { studies; regional } \\
\text { land use planning }\end{array}$ \\
\hline $\begin{array}{l}\text { Detailed } \\
\text { (Level 2) }\end{array}$ & $\begin{array}{c}1: \\
25000 \\
\text { to } \\
1: \\
10000\end{array}$ & $\begin{array}{c}1: \\
25000 \\
1: \\
20000 \\
1: \\
10000\end{array}$ & $\begin{array}{c}6.25 \text { ha } \\
5 \text { ha } \\
1 \text { ha }\end{array}$ & $\begin{array}{l}250 \mathrm{~m} \\
200 \mathrm{~m} \\
100 \mathrm{~m}\end{array}$ & $\begin{array}{l}\text { Series, phases } \\
\text { of series, some } \\
\text { associations } \\
\text { and complexes }\end{array}$ & $\begin{array}{c}\text { Agricultural } \\
\text { advisory work, } \\
\text { project planning, } \\
\text { irrigation } \\
\text { surveys, some } \\
\text { management and } \\
\text { peri-urban } \\
\text { surveys }\end{array}$ \\
\hline $\begin{array}{l}\text { Intensive } \\
\text { (Level 1) }\end{array}$ & $\begin{array}{c}\text { larger } \\
\text { than } \\
1: \\
10000\end{array}$ & $\begin{array}{l}1: \\
5000\end{array}$ & 0.25 ha & $50 \mathrm{~m}$ & $\begin{array}{l}\text { Series, phases } \\
\text { of series, } \\
\text { individual soil } \\
\text { properties }\end{array}$ & $\begin{array}{l}\text { Management, } \\
\text { peri-urban and } \\
\text { urban soil } \\
\text { surveys, } \\
\text { invariably } \\
\text { special-purpose }\end{array}$ \\
\hline
\end{tabular}

Source: Dent and Young (1981:90) 


\subsection{Validation of the LTSIV algorithm's accuracy for inclusion in the FVSS}

The accuracy of the LTSIV algorithm was confirmed by soil suitability data of the Breede and Berg River areas that were obtained by soil scientists by means of a reconnaissance soil survey on a semi-detailed scale (1:50 000). The maps were done for irrigation planning purposes. The deviation between the LTSIV results and the Breede River data proved to be no more than 20 percent (Figure 13). More deviation existed in the Berg River area due to inaccuracies occurring in the land type data set for some parts, but for the largest part of this area a deviation of less than 20 percent occurred (Figure 14). These small deviation percentages serve as scientific evidence that the LTSIV algorithm delivered reliable results and can therefore be successfully included in the FVSS. This then distinguishes the proposed FVSS from other existing property valuation systems and can therefore be used by valuers as a first approximation of a property's soil suitability, before doing further field work. It would be desirable to test the algorithm against similar data in other parts of the country, but such data is not yet readily available.

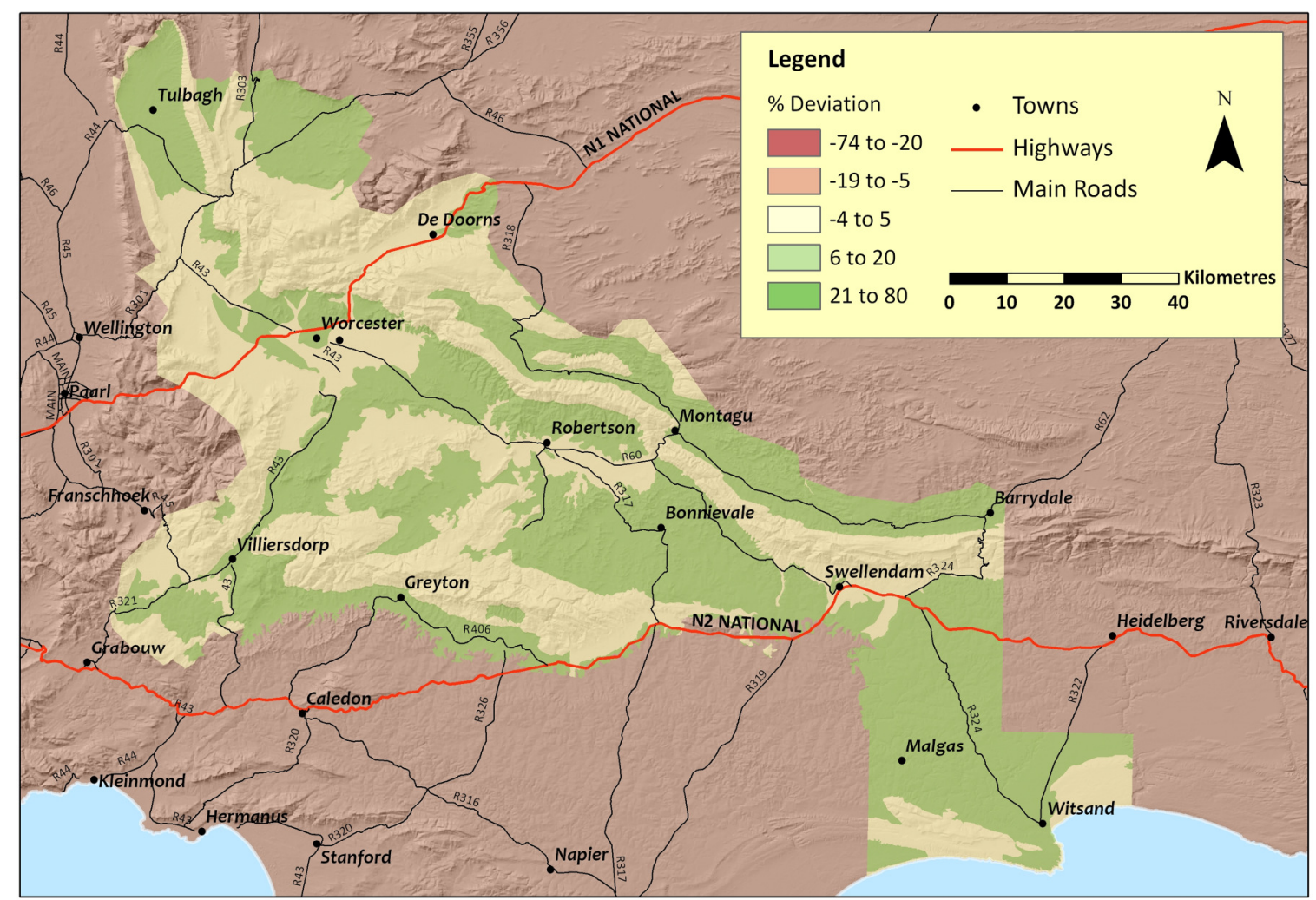

Figure 13: Deviation (\%) between the Breede River reconnaissance soil survey data (scale of 1:50 000) and the LTSIV results as indication of the LTSIV algorithm's accuracy. 


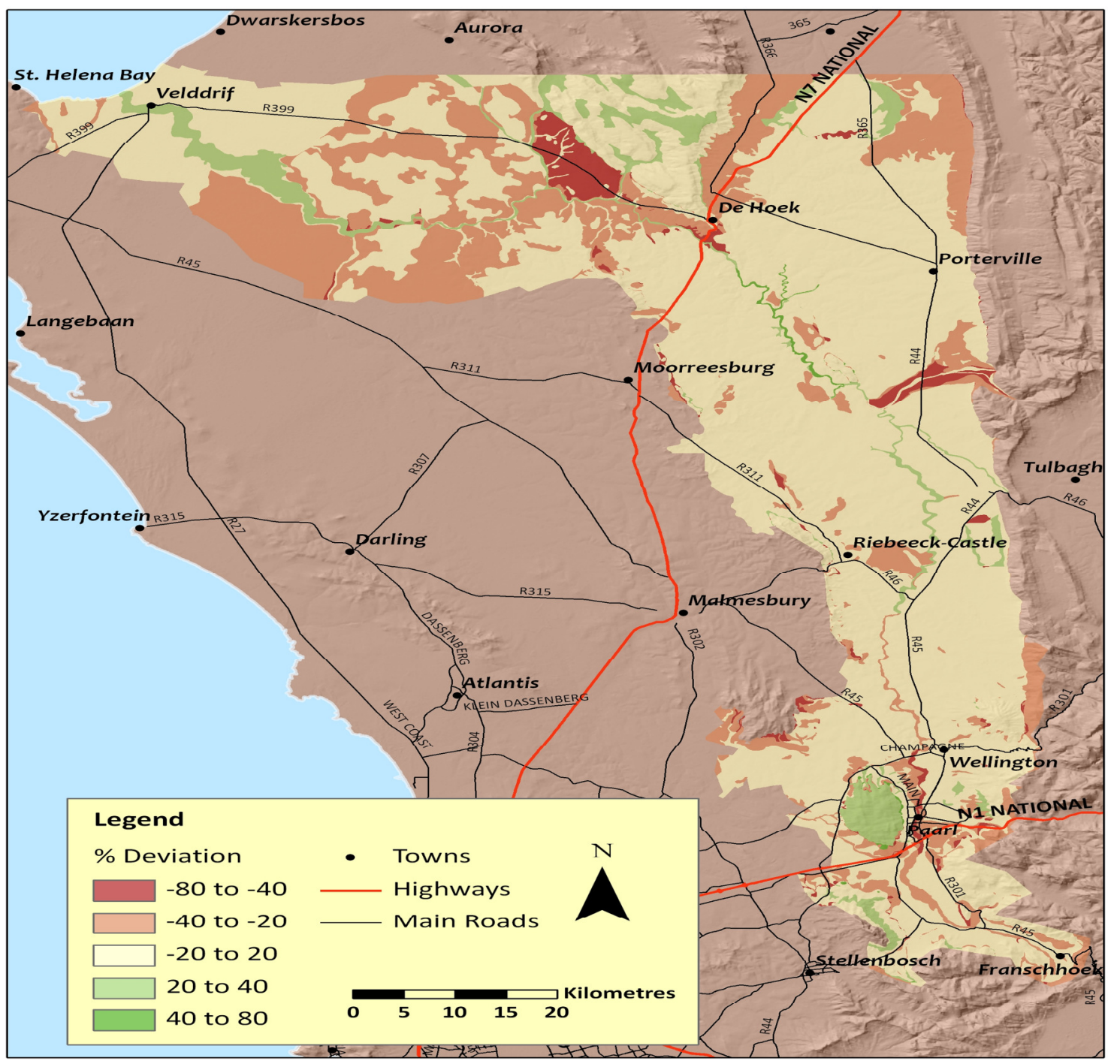

Figure 14: Deviation (\%) between the Berg River reconnaissance soil survey data $(1: 50$ 000) and the LTSIV results as indication of the LTSIV algorithm's accuracy.

\subsection{Distribution}

The strategy should be to make the FVSS consumer driven: affordable, accessible and available. The best way to achieve this is through a web-based system.

Principles to create consuming capacity for products:

- Affordability: affordable without sacrificing quality or efficacy

- Access: reach distribution point

- Availability: distribution efficiency (Prahalad, 2006:18). 
Arrangements with WinDeed should be made to electronically link the databases of the Deeds Office to the National Mapping Organization (NMO). The strategy makes geo-information available electronically and makes it possible to trade on the internet. This will fulfil the need for rapid data collection, processing and dissemination to consumers.

\subsection{Conclusion}

The proposed farm valuation support system (FVSS) developed in this chapter reached the first research objective by demonstrating how the valuer will be able to rapidly identify the location of the subject farm property and transaction farms on an electronic map. The second research objective was reached by demonstrating how the proposed FVSS enables the valuer to compare farm properties based on their respective locations and value bearing characteristics. The algorithm in this chapter delivered a land type suitability index value (LTSIV), which accurately reveals the agricultural suitability of different land types and therefore successfully reached this study's third research objective. 


\section{CONCLUSIONS AND SUMMARY}

\subsection{Conclusions}

The comparable sales transaction approach is used for the valuation of farms and residential properties. The subject property is compared with transaction properties on the basis of value bearing characteristics. For the valuation of residential properties already existing spatial information systems are used to identify the location of the subject property and transaction properties to each other and to other places of interest. It therefore saves the valuer time. These information systems, however, only has location information and no information on soil quality. Soil quality is irrelevant for residential, commercial and industrial properties.

Several spatial data sets (spatial data coverages) already exist and are used for agricultural planning purposes. The central question of this thesis is whether these agricultural spatial data sets can provide information relevant to valuers and estate agents involved in farm valuations. An extensive search of international literature revealed that a spatial information system that incorporates soil quality, which is relevant for the valuation of farms where soil quality affects the farm's production potential, does not yet exist.

A survey was done among valuers and estate agents to determine their needs in respect of spatial information. Further needs of buyers of lifestyle properties were obtained from a recent study that focused on the characteristics of farms appreciated by lifestyle buyers in the intensive and extensive areas of the Western Cape Province. Characteristics that were proven statistically meaningful by the study should be considered by valuers when valuing farms. These identified needs were then used as guidelines to select existing agricultural spatial data sets to be included in a farm valuation support system (FVSS) that would enable valuers to quickly compare a subject property with transaction properties.

The existing soil quality spatial data sets used by soil scientists for agricultural planning purposes are too complicated for valuers as non-soil scientists to interpret. This problem led to the following research question: Can a simple measure, giving a reliable reflection of soil quality, be developed from existing soil spatial data sets? An 
algorithm was therefore created that integrates specific soil data namely effective soil depth, texture and a combination of soil series attributes to generate a land type suitability index value (LTSIV), which reveals the agricultural suitability of different land types for annual and perennial crop production.

To validate whether the LTSIV reflects the soil suitability of different areas sufficiently accurately, it was tested against soil suitability data of the Breede and Berg River areas, which were obtained by soil scientists by means of a reconnaissance soil survey. The test results indicated that the LTSIV is accurate enough to be successfully included in the FVSS.

The FVSS will be able to assist the valuer in rapidly identifying the location of the subject property and transaction properties on an electronic map, showing the farm to be valued in its proper setting with reference to surrounding farms and territory with visual coverage of land type boundaries, rivers, roads, the location of buildings on the farm and contour lines indicating the topography of the property. A property information table, containing relevant value bearing characteristics of the subject property and of each transaction property selected by the valuer, was included in the FVSS to be used by valuers when comparing properties with each other.

This study therefore succeeded in its aim to develop a blueprint for a farm valuation support system based on spatial data that assists valuers in their application of the comparable sales method.

\subsection{Summary}

This study has been subdivided into six chapters, a list of references and annexures.

The first chapter served to introduce the study, as well as to structure and orient it. Firstly, it described the background and the three research objectives, which were answered in subsequent sections of the study. A preview of the layout and contents of the chapters was provided.

Chapter 2, the 'Literature Review', reviewed scientific articles and books that related to the scope of the study. First an introduction to the literature on land valuation was 
provided. This was followed by sections covering the literature on fundamental valuation theory with regard to the comparable sales approach, as well as on literature concerning the comparable sales method of valuation and its comparison with the income and cost methods of valuation.

Chapter 3 includes a nationwide survey that was done among valuers and estate agents specialising in farm valuations. Questionnaires were distributed nationwide and 96 were completed and successfully retrieved. The survey collected demographic information and demonstrated that the need for a farm valuation support system does exist and that it will be used by valuers. The survey also collected information that provided guidelines for the design of a farm valuation support system (FVSS) that enables the valuer to compare a subject farm with transaction farms based on relevant value bearing attributes.

Chapter 4 gave a general introduction to Geographic Information Systems (GIS) and its implementation and application in agriculture. The most efficient way to distribute information followed by comparing PC-based Decision Support Systems (DSS) with web-based DSS, as well as an investigation of the potential of Web-GIS. The chapter also focused on the abilities of already existing property valuation software namely: SAPTG (South African Property Transfer Guide), Deedsweb (Windeed and Aktex) and Lightstone. These popular property valuation software packages were found to contain no information about resource quality which is precisely the information needed for farm valuations.

Chapter 5 dealt with the development, functionality and validation of the proposed FVSS. Firstly, factors affecting farm land suitability were reviewed. The chapter then focused on reaching the third research objective and answered the research question of whether a simple reliable measure of soil quality can be developed from existing soil spatial data sets. To achieve this, specific soil data namely effective soil depth, texture and a combination of soil series attributes were used to create an algorithm that delivered a land type suitability index value (LTSIV), which accurately reveals the agricultural suitability of different land types. Validation of the LTSIV algorithm's accuracy is confirmed later on in the chapter where it was tested against soil suitability data of the Breede and Berg River areas, which were obtained by soil scientists by means of a reconnaissance soil survey. 
The chapter also provided a printout of an electronic map to demonstrate how the proposed FVSS reached the first research objective by enabling the valuer to rapidly identify the location of the subject farm property and transaction farms on an electronic map. The second research objective was reached by demonstrating on a printout of an electronic map how the proposed FVSS enables the valuer to compare farm properties based on their respective locations with regard to land type boundaries, rivers, roads, buildings and contour lines indicating the topography of each farm. In addition to the map, a property information table is provided. The table contains valuable information about the subject farm and each transaction farm selected by the valuer, which enables him/her to compare farms based on important value bearing characteristics. The chapter also provided the type and scale of data sets included in the FVSS.

This last chapter presented the conclusions of the study, followed by this summary. In turn, this is followed by the 'References' and a series of annexures. 
Acocks, J.P.H. 1988. Veld types of South Africa. Mem. Bot. Surv. S. Afr. No. 57.

ASFMRA. 2011. American society of farm managers and rural appraisers [online]. Sales comparison approach, 7, 6. Available from: http://www.econ.iastate.edu/classes/econ364/duffy/documents/salescomparis onsfromntbk.pdf/ [Accessed 5 May 2011].

Bastian, C. T., McLeod, D. M., Germino, M. J., Reiners, W. A. and Blasko, B. J. (2002). Environmental amenities and agricultural land values: a hedonic model using geographic information systems data. Ecological Economics 40:337-349.

Bertolotto, M., Carswell, J.D., McGeown, L., McMahon, J., 2002. Web-Based Spatial Information Management Systems. In: Proceedings 95th Annual CIG Conference, Ottawa,Canada.

Boehlje, M.D. and Eidman, V.R. 1984. Farm management. John Wiley, New York.

Burger, J. B. 1990. Plaaswaardasies: teorie en praktyk in Suid-Afrika. Universiteit van Stellenbosch.

Carey, V.A. 2005. The use of viticultural terroir units for demarcation of geographical indicators for wine production in Stellenbosch and surrounds. PhD dissertation. Stellenbosch: Stellenbosch University, Dept of Viticulture and Oenology.

CDSM. 2007. Maps of the national series [online]. Cape Town: CDSM. Available from: http://w3sli.wcape.gov.za/ [Accessed 21 September 2007].

Ceballos-Silva, A. and López-Blanco, J. 2003a. Delineation of suitable areas for crops using a multi-criteria evaluation approach and land use/cover mapping: A case study in Central Mexico. Agricultural systems, 77, 117-136. 
Ceballos-Silva, A. and López-Blanco, J. 2003b. Evaluating biophysical variables to identify suitable areas for oats in Central Mexico: A multi-criteria and GIS approach. Agriculture, Ecosystems and Environment, 95, 371-377.

Chang, K. 2008. Introduction to Geographic Information Systems (4th edition). McGraw-Hill Education, New York.

Cools, N., De Pauw, E. and Deckers, J. 2002. Towards an integration of conventional land evaluation methods and farmers' soil suitability assessment: A case study in northwestern Syria. Agriculture, Ecosystems and Environment, 1-16.

DEAT. 2006. The South Africa Environment Outlook report [online]. Available from: http://www.environment.gov.za/Hotlssues/2006/staeoftheenvironment2006/St ateOfTheEnvironment2006.html/.

De Jongh, P. J. 1975. Die grondmark in Suid-Afrika met ' $n$ spesifieke verwysing na Pretoria. Fakulteit Ekonomiese en Staatswetenskappe. Universiteit van Pretoria.

De la Rosa, D., Mayol, F., Diaz-Pereira, F., Fernandez, M. and De la Rosa, D. 2004. A land evaluation decision support system (MicroLEIS DSS) for agricultural soil protection with special reference to the Mediterranean region. Environmental Modelling and Software, 19, 929-942.

Dendgiz, O., Bayramin, Ú. and Yüksel, M. 2003. Geographic information systems and remote sensing based land evaluation of BeypazarỲ area soils by ILSEN model. Turkish Journal of Agriculture and Forestry, 27, 145-153.

Dent, D. and Young, A. 1981. Soil survey and land evaluation. School of Environmental Sciences, University of East Anglia, Norwich. 
Dent, P. and Temple, M. 1998. Economic value - a methodological dilemma? Centre for Real Estate Management, School of Architecture, Oxford Brookes University.

Ellenberger, E. L. 1983. The valuer and the basic principles of property valuation in South Africa.

FAO. 1976. A framework for land evaluation. The FAO soils bulletins. Food and Agriculture Organization of the United Nations Soil Resources, Development and Conservation. Rome.

Foth, H.D. and Turk, L.M. 1972. Fundamentals of Soil Science (5th edition). John Wiley and Sons, New York.

Friedman, J.P. and Lindeman, J.B. 2005. Barron's how to prepare for the California Real Estate Exams. (2nd edition). Part 4: Real Estate Analysis. Educational Series, Inc.

Friedman, T. L. 2006. The world is flat: the globalized world in the twenty-first century. Penguin Group.

Hayles, K. and Grenfell, R. 2002. Data integration: An application in rural property evaluation.

International Valuation Standards. 2005. International Valuation Standards Committee (IVSC) (7th edition). London United Kingdom.

Lambrechts, J.J.N. and Ellis, F. 2010. Personal Communication. Stellenbosch: Stellenbosch University.

Land Type Survey Staff. 1984. Land types of the maps 2626 Wes-Rand \& 2726 Kroonstad. Pretoria: Department of Agriculture.

Lewis, A. 2007. WordWeb Computer Program (5th edition). Prinston University. 
Lombard, J.P. 1993. 'n Stogasiese besluitnemingsmodel vir die evaluering van landbougrondtransaksies in die Wes- en Suid-Kaap. Stellenbosch Universiteit. Junie, 1993.

Lornadawn Investments (PTY) Ltd. v. Minister of Agriculture. 1977. Cases decided in The Supreme Court of South Africa. SA Law Reports. April 1980. (Appèlafdeling).

MacVicar, C.N., Scotney, D.M., Skinner, T.E., Niehaus, H.S. and Laubscher, J.H. 1974. A classification of land (climate, terrain form, soil) primarily for rainfed agriculture. South African Journal of Agricultural Extension, 22.

McFetridge, G. 2008. Maximizing the use of GIS to enhance assessment methods [online]. Available from: http://gis.esri.com/library/userconf/proc03/p0460.pdf [Accessed 17 September 2008].

Murray, W. G. 1969. Farm appraisal and valuation (5th edition).

Pietermaritzburg Corporation v. S.A. Breweries Ltd., 1911. Cases decided in The Supreme Court Of South Africa. SA Law Reports. April 1980. (Appèlafdeling).

Prahalad, C.K. 2006. The Fortune at the Bottom of the Pyramid. Wharton School Publishing.

Reed, L.L. 2009. A reinterpretation of the value attributes of agricultural land for the valuation of farms bought for lifestyle purposes. $\mathrm{PhD}$ (Agric) University of Stellenbosch, March 2009.

Reiger, M. 2006. Introduction to fruit crops. New York: Haworth Press.

Richardson, E. A., Seeley, S. D. and Walker, D. R. 1974. A model for estimating the completion of rest for 'Redhaven' and 'Alberta' peach trees. HortScience, 9 , 331-332. 
Rossiter, D.G. 1996. A theoretical framework for land evaluation. Geoderma, 72,165-190.

Schulze, R.E. 1997. South African atlas of agrohydrology and -climatology. Report TT82/96. Pretoria: Water Research Commission.

Scotney, D.M., Ellis, F., Nott, R.W., Taylor, K.P., Van Niekerk, B.J., Verster, E. and Wood, P.C. 1987. A system of soil and land capability classification for agriculture in the TBVC states. Technical Committee for Agriculture and Environmental Affairs.

Spahr, R. W. and Sunderman, M. A. (1999). Valuation of property surrounding a resort community. Journal of Real Estate Research 17(1):227-243.

Van Der Watt, H. V. H. and Van Rooyen, T. H. 1995. A Glossary of Soil Science (2nd edition). Pretoria. The Soil Science Society of South Africa.

Van Niekerk, A. 2008. CLUES: a web-based land use expert system for the Western Cape. Geology, Geography \& Environmental Studies Department. Stellenbosch University.

Webb, R.B. 1994. On the reliability of commercial appraisals: An analysis of properties sold from the Russel-NCREIF Index (1978-1992). Real Estate Finance, 1, 62-65. 


\section{APPENDICES}

$\begin{array}{lll}\text { Appendix A Questionnaire: Valuers' Preferences regarding a spatial } 70 & 70\end{array}$ information system for valuing farms

Appendix B LTSIV calculation tables of land types: Ac481; Ca38;

Fb544 and Ha11

Appendix C Land type Ca6

Appendix D

The Algorithm's lookup table 76 


\section{APPENDIX A}

\section{QUESTIONNAIRE: VALUERS' PREFERENCES REGARDING A SPATIAL INFORMATION SYSTEM FOR VALUING FARMS}

\section{PROFILE OF VALUER}

1.1 Status: Professional valuer $\square \quad$ Associate valuer $\square \quad$ Candidate valuer $\square$ Property agent $\square$ Other $\square$ Name:

1.2 Gender:

1.3 Age:

1.4 For how many years have you been valuing property?

1.5 For how many years have you been valuing farms?

1.6 What percentage of the total number of valuations done per annum do farm valuations represent?:

1.7 Do you make use of a residential property spatial database? Yes $\square$ No $\square$ Name of database:

1.8 In which district do you live?

1.9 In which district do you do the most valuations? Second most? Third most?

1.10 For which type of organisation do you do the most farm valuations? (\% of your time)

Commercial banks $\square \quad$ (Potential) buyers/ sellers (Individuals, business enterprises) $\square$ Local government $\square \quad$ Government departments $\square$

Other $\square$ Name/s:

\section{USE OF WINXFER/LIGHTSTONE}

2.1 Do you use WinXfer/Lightstone to find farms and smallholdings? Yes $\square \quad$ No $\square$

2.2 How many districts' monthly reports do you retrieve on average per month?

2.3 Would you prefer to identify potentially comparable properties via WinXfer/Lightstone before you 'clean' them in order to compile a shortlist of properties, PRIOR to determining their location with the proposed spatial information system?

$$
\text { Yes } \square
$$

OR Would you prefer to get all transaction properties over a predetermined period automatically on the map of the proposed spatial information system linked to WinXfer/Lightstone, in order to 'clean' them afterwards? 


\section{COMPUTER SKILLS}

\begin{tabular}{|l|l|l|l|l|}
\hline SOFTWARE & No skills & $\begin{array}{l}\text { Limited } \\
\text { skills }\end{array}$ & Quite skilled & $\begin{array}{l}\text { Highly } \\
\text { skilled }\end{array}$ \\
\hline Word processing (MS Word, etc.) & & & & \\
\hline Spreadsheet (Excel, etc.) & & & & \\
\hline $\begin{array}{l}\text { Internet mapping system (Map } \\
\text { Source, etc.) }\end{array}$ & & & & \\
\hline Google Earth ArcGIS, PlanetGIS & & & & \\
\hline $\begin{array}{l}\text { GIS (Arclnfo, Ars.) } \\
\text { etc.) }\end{array}$ & & & \\
\hline
\end{tabular}

\section{COMPUTER INFRASTRUCTURE}

Computer connection: Choose all the relevant options: Modem $\square$ ADSL line $\square$ Internal network $\square$

\section{HOW IMPORTANT ARE THE FOLLOWING CHARACTERISTICS/ CAPACITY OF THE INFORMATION SYSTEM FOR YOU?}

\begin{tabular}{|l|l|l|l|l|}
\hline & $\begin{array}{l}1= \\
\text { Not } \\
\text { important }\end{array}$ & $\begin{array}{l}2=\text { Of low } \\
\text { importance }\end{array}$ & $\begin{array}{l}3=\text { Of high } \\
\text { importance }\end{array}$ & $\begin{array}{l}4= \\
\text { Very } \\
\text { Important }\end{array}$ \\
\hline $\begin{array}{l}\text { Determining the location of subject and transaction } \\
\text { properties in terms of cadastral maps }\end{array}$ & & & & \\
\hline & & & & \\
\hline $\begin{array}{l}\text { Determining the location of subject and transaction } \\
\text { properties in terms of roads }\end{array}$ & & & & \\
\hline & & & & \\
\hline $\begin{array}{l}\text { Determining the location of subject and transaction } \\
\text { properties in terms of villages }\end{array}$ & & & & \\
\hline $\begin{array}{l}\text { Determining the location of subject and transaction } \\
\text { properties in terms of rivers }\end{array}$ & & & & \\
\hline $\begin{array}{l}\text { Determining the location of subject and transaction } \\
\text { properties in terms of railroads }\end{array}$ & & & & \\
\hline & & & & \\
\hline $\begin{array}{l}\text { Determining the location of subject and transaction } \\
\text { properties in terms of power lines }\end{array}$ & & & & \\
\hline & & & & \\
\hline $\begin{array}{l}\text { Determining the location of subject and transaction } \\
\text { properties in terms of topography }\end{array}$ & & & & \\
\hline & & & & \\
\hline $\begin{array}{l}\text { Determining the location of subject and transaction } \\
\text { properties in terms of land type (surface potential) }\end{array}$ & & & & \\
\hline & & & & \\
\hline $\begin{array}{l}\text { Determining the location of subject and transaction } \\
\text { properties in terms of field type }\end{array}$ & & & & \\
\hline $\begin{array}{l}\text { Determining the location of subject and transaction } \\
\text { properties in terms of rainfall pattern }\end{array}$ & & & & \\
\hline & & & & \\
\hline $\begin{array}{l}\text { Determining the location of subject and transaction } \\
\text { properties in terms of temperature regimes }\end{array}$ & & & & \\
\hline & & & & \\
\hline
\end{tabular}




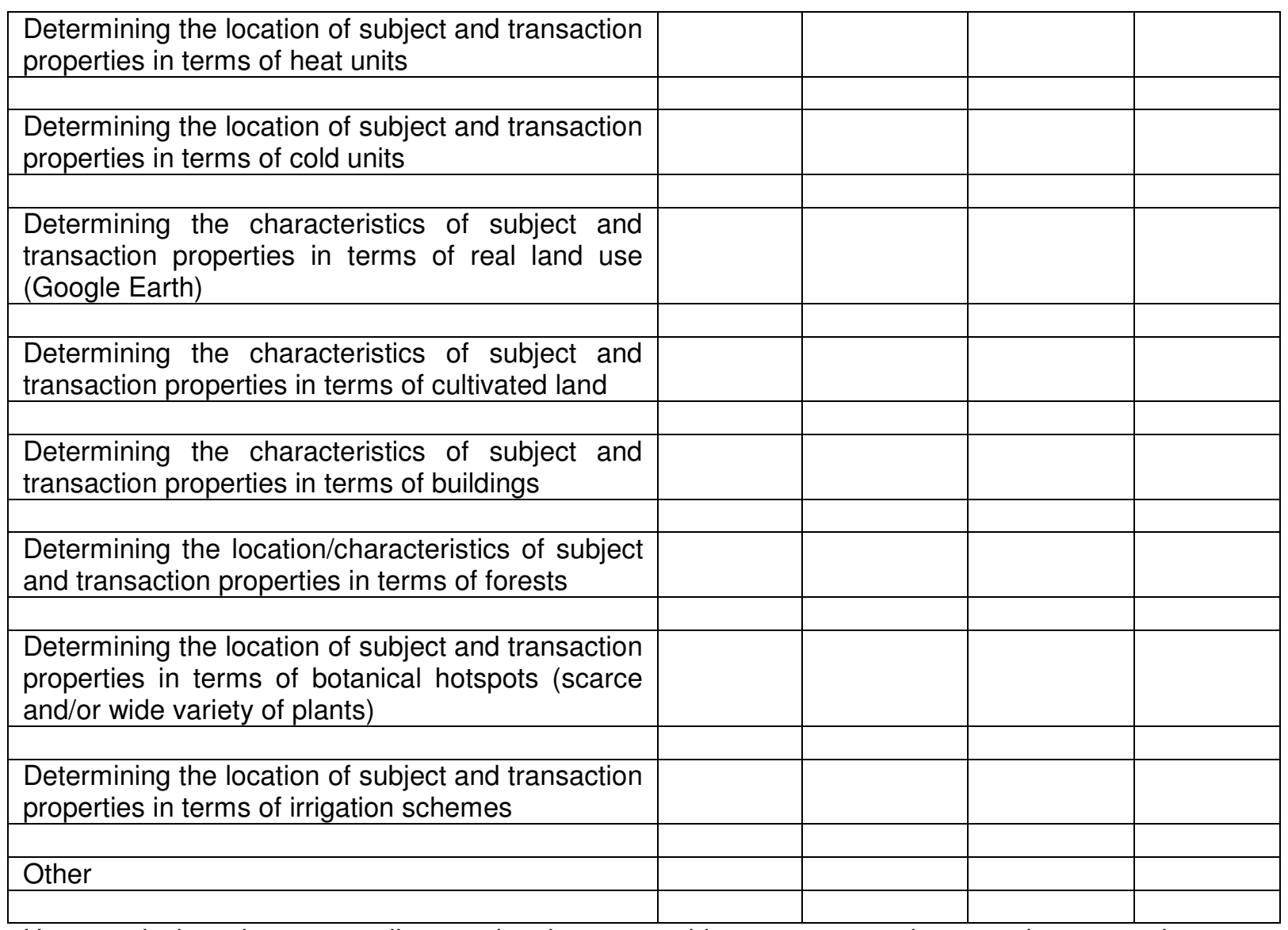

How much time do you usually spend to locate a subject property and transaction properties on a map when you do a valuation? .hours

What is the hourly rate that you normally charge (to calculate the potential saving via using the information system).....R

\section{PLEASE SAVE THE COMPLETED DOCUMENT}

Thank you for your cooperation. 


\section{APPENDIX B}

LTSIV CALCULATION TABLES OF LAND TYPES: Ac481; Ca38; Fb544 and Ha11

Table 15: LTSIV calculation table of land type Ac481

\begin{tabular}{|c|c|c|c|c|c|c|c|c|}
\hline $\begin{array}{c}\text { Soil Series } \\
\text { present in } \\
\text { land type } \\
\text { Ac481 }\end{array}$ & $\begin{array}{c}\% \text { Area of } \\
\text { land type } \\
\text { Ac481 } \\
\text { covered } \\
\text { by soil } \\
\text { series }\end{array}$ & $\begin{array}{c}\text { Soil } \\
\text { Series } \\
\text { Suitability } \\
\text { Rating } \\
\text { (SSSR) }\end{array}$ & Depth class & $\begin{array}{l}\text { Effective } \\
\text { Soil Depth } \\
\text { Rating (D) }\end{array}$ & $\begin{array}{c}\text { Texture } \\
\text { class }\end{array}$ & $\begin{array}{c}\text { Texture } \\
\text { Class } \\
\text { Rating }(\mathrm{T})\end{array}$ & $\begin{array}{l}\text { Depth- } \\
\text { Texture } \\
\text { Index } \\
\text { Value (DT) }\end{array}$ & $\begin{array}{c}\text { Soil } \\
\text { Series } \\
\text { Index } \\
\text { Value } \\
\text { (SSIV) }\end{array}$ \\
\hline$R$ & 2.3 & 1.0 & D5 & 1.0 & T3 & 6 & 3.3 & 0.07 \\
\hline Ms 10 & 1.1 & 2.5 & D4 & 2.5 & T2 & 8 & 5.3 & 0.14 \\
\hline Hu26 & 16.1 & 8.3 & D1 & 10.0 & T1 & 10 & 10.0 & 13.28 \\
\hline Sw11 & 7.8 & 4.3 & D3 & 5.0 & T1 & 10 & 7.5 & 2.49 \\
\hline Sw31 & 5.2 & 3.8 & D3 & 5.0 & T1 & 10 & 7.5 & 1.46 \\
\hline Gs13Gs12 & 2.2 & 4.9 & D4 & 2.5 & T2 & 8 & 5.3 & 0.56 \\
\hline $\mathrm{Kd} 22$ & 8.4 & 3.5 & $\mathrm{D} 2$ & 7.5 & T3 & 6 & 4.9 & 1.43 \\
\hline Oa36 & 3.1 & 7.0 & D1 & 10.0 & T1 & 10 & 10.0 & 2.17 \\
\hline Va30 & 3.1 & 4.3 & D3 & 5.0 & T1 & 10 & 7.5 & 0.99 \\
\hline Ss26 & 1.2 & 4.3 & D3 & 5.0 & T1 & 10 & 7.5 & 0.38 \\
\hline Cv24Cv21 & 6.0 & 6.6 & D1 & 10.0 & T3 & 6 & 5.5 & 2.19 \\
\hline Wa31 & 3.4 & 4.0 & D3 & 5.0 & $\mathrm{~T} 2$ & 8 & 6.5 & 0.88 \\
\hline Ms11 & 2.3 & 3.3 & D4 & 2.5 & $\mathrm{~T} 2$ & 8 & 5.3 & 0.39 \\
\hline Cv24Cv25 & 17.4 & 7.5 & $\mathrm{D} 2$ & 7.5 & $\mathrm{~T} 2$ & 8 & 7.8 & 10.11 \\
\hline Hu26 & 6.2 & 8.3 & D2 & 7.5 & T1 & 10 & 8.8 & 4.48 \\
\hline Hu26Hu25 & 13.2 & 7.9 & D2 & 7.5 & T2 & 8 & 7.8 & 8.06 \\
\hline We22 & 0.7 & 3.8 & D4 & 2.5 & $\mathrm{~T} 1$ & 10 & 6.3 & 0.16 \\
\hline & & & & & & & $\begin{array}{c}\text { Land Type } \\
\text { Suitability } \\
\text { Index } \\
\text { Value } \\
\text { (LTSIV) }\end{array}$ & 49.24 \\
\hline
\end{tabular}

Table 16: LTSIV calculation table of land type Ca38

\begin{tabular}{|c|c|c|c|c|c|c|c|c|}
\hline $\begin{array}{l}\text { Soil Series } \\
\text { present in } \\
\text { land type } \\
\text { Ca38 }\end{array}$ & $\begin{array}{c}\% \text { Area of } \\
\text { land type } \\
\text { Ca38 } \\
\text { covered } \\
\text { by soil } \\
\text { series }\end{array}$ & $\begin{array}{c}\text { Soil } \\
\text { Series } \\
\text { Suitability } \\
\text { Rating } \\
\text { (SSSR) }\end{array}$ & Depth class & $\begin{array}{l}\text { Effective } \\
\text { Soil Depth } \\
\text { Rating (D) }\end{array}$ & $\begin{array}{l}\text { Texture } \\
\text { class }\end{array}$ & $\begin{array}{c}\text { Texture } \\
\text { Class } \\
\text { Rating }(\mathrm{T})\end{array}$ & $\begin{array}{c}\text { Depth- } \\
\text { Texture } \\
\text { Index } \\
\text { Value (DT) }\end{array}$ & $\begin{array}{l}\text { Soil } \\
\text { Series } \\
\text { Index } \\
\text { Value } \\
\text { (SSIV) }\end{array}$ \\
\hline Wa20Wa30 & 16.9 & 3.6 & D3 & 5.0 & T3 & 6 & 4.3 & 2.59 \\
\hline Wa10 & 3.1 & 3.3 & D3 & 5.0 & T3 & 6 & 4.3 & 0.43 \\
\hline Ms11 & 18.5 & 3.3 & D4 & 2.5 & T3 & 6 & 3.6 & 2.18 \\
\hline Kd22Kd15 & 9.3 & 3.9 & D2 & 7.5 & T3 & 6 & 4.9 & 1.77 \\
\hline $\mathrm{Kd} 21 \mathrm{Kd} 14$ & 9.2 & 3.9 & D2 & 7.5 & T3 & 6 & 4.9 & 1.75 \\
\hline $\mathrm{Kd} 11 \mathrm{Kd} 12$ & 9.3 & 3.5 & D3 & 5.0 & T3 & 6 & 4.3 & 1.38 \\
\hline Fw11Fw12 & 11.1 & 3.9 & D1 & 10.0 & T3 & 6 & 5.5 & 2.38 \\
\hline Lo21Lo22 & 5.3 & 4.1 & $\mathrm{D} 2$ & 7.5 & T1 & 10 & 8.8 & 1.90 \\
\hline Cv24Hu24 & 4.0 & 7.5 & D1 & 10.0 & T3 & 6 & 5.5 & 1.65 \\
\hline $\mathrm{R}$ & 2.4 & 1.0 & D5 & 1.0 & T3 & 6 & 3.3 & 0.08 \\
\hline Ms10 & 0.6 & 2.5 & D4 & 2.5 & T3 & 6 & 3.6 & 0.05 \\
\hline Du100a36 & 10.2 & 4.9 & D1 & 10.0 & T1 & 10 & 10.0 & 5.03 \\
\hline & & & & & & & $\begin{array}{l}\text { Land Type } \\
\text { Suitability } \\
\text { Index } \\
\text { Value } \\
\text { (LTSIV) }\end{array}$ & 21.19 \\
\hline
\end{tabular}


Table 17: LTSIV calculation table of land type Fb544

\begin{tabular}{|l|c|c|c|c|c|c|c|c|}
\hline $\begin{array}{c}\text { Soil Series } \\
\text { present in land } \\
\text { type Fb544 }\end{array}$ & $\begin{array}{c}\text { \% Area of } \\
\text { land type } \\
\text { Fb544 } \\
\text { covered } \\
\text { by soil } \\
\text { series }\end{array}$ & $\begin{array}{c}\text { Soil Series } \\
\text { Suitability } \\
\text { Rating } \\
\text { (SSSR) }\end{array}$ & $\begin{array}{c}\text { Depth } \\
\text { class }\end{array}$ & $\begin{array}{c}\text { Effective } \\
\text { Soil Depth } \\
\text { Rating (D) }\end{array}$ & $\begin{array}{c}\text { Texture } \\
\text { class }\end{array}$ & $\begin{array}{c}\text { Texture } \\
\text { Class } \\
\text { Rating (T) }\end{array}$ & $\begin{array}{c}\text { Depth- } \\
\text { Texture } \\
\text { Index Value } \\
\text { (DT) }\end{array}$ & $\begin{array}{c}\text { Soil Series } \\
\text { Index } \\
\text { Value } \\
\text { (SSIV) }\end{array}$ \\
\hline R & 10.2 & 1.0 & D5 & 1.0 & T3 & 6 & 3.3 & 0.33 \\
\hline Ms10 & 15.2 & 2.5 & D4 & 2.5 & T1 & 10 & 6.3 & 2.38 \\
\hline Gs13Gs16Gs14 & 10.9 & 5.4 & D4 & 2.5 & T1 & 10 & 6.3 & 3.66 \\
\hline Sw10Sw11 & 23.5 & 4.4 & D3 & 5.0 & T1 & 10 & 7.5 & 7.71 \\
\hline Sw31 & 9.0 & 3.8 & D3 & 5.0 & T1 & 10 & 7.5 & 2.53 \\
\hline Va31 & 9.2 & 3.8 & D3 & 5.0 & T1 & 10 & 7.5 & 2.59 \\
\hline Hu24Hu26 & 9.8 & 7.9 & D2 & 7.5 & T3 & 6 & 4.9 & 3.77 \\
\hline Cv24Cv26 & 9.3 & 7.9 & D1 & 10.0 & T3 & 6 & 5.5 & 4.04 \\
\hline Du10O336 & 2.8 & 4.9 & D1 & 10.0 & T2 & 8 & 9.0 & 1.24 \\
\hline
\end{tabular}

Table 18: LTSIV calculation table of land type Ha11

\begin{tabular}{|c|c|c|c|c|c|c|c|c|}
\hline $\begin{array}{c}\text { Soil Series } \\
\text { present in } \\
\text { land type } \\
\text { Ha11 }\end{array}$ & $\begin{array}{c}\% \text { Area of } \\
\text { land type } \\
\text { Ha11 } \\
\text { covered } \\
\text { by soil } \\
\text { series }\end{array}$ & $\begin{array}{c}\text { Soil } \\
\text { Series } \\
\text { Suitability } \\
\text { Rating } \\
\text { (SSSR) }\end{array}$ & Depth class & $\begin{array}{l}\text { Effective } \\
\text { Soil Depth } \\
\text { Rating (D) }\end{array}$ & $\begin{array}{c}\text { Texture } \\
\text { class }\end{array}$ & $\begin{array}{c}\text { Texture } \\
\text { Class } \\
\text { Rating }(\mathrm{T})\end{array}$ & $\begin{array}{c}\text { Depth- } \\
\text { Texture } \\
\text { Index } \\
\text { Value (DT) }\end{array}$ & $\begin{array}{c}\text { Soil } \\
\text { Series } \\
\text { Index } \\
\text { Value } \\
\text { (SSIV) }\end{array}$ \\
\hline Fw10Fw11 & 47.1 & 3.8 & D1 & 10.0 & T3 & 6 & 5.5 & 9.71 \\
\hline Fw20Fw21 & 5.2 & 3.8 & D1 & 10.0 & T3 & 6 & 5.5 & 1.07 \\
\hline Ct10Ct11 & 27.9 & 3.8 & D1 & 10.0 & T3 & 6 & 5.5 & 5.75 \\
\hline Lt10Lt11 & 3.5 & 3.8 & D1 & 10.0 & T3 & 6 & 5.5 & 0.72 \\
\hline Kd11 & 5.0 & 3.5 & D1 & 10.0 & T3 & 6 & 5.5 & 0.96 \\
\hline $\mathrm{R}$ & 4.6 & 1.0 & D5 & 1.0 & T3 & 6 & 3.3 & 0.15 \\
\hline Ms10 & 0.6 & 2.5 & D4 & 2.5 & T3 & 6 & 3.6 & 0.05 \\
\hline Gs14Gs15 & 0.7 & 5.3 & D3 & 5.0 & $\mathrm{~T} 2$ & 8 & 6.5 & 0.24 \\
\hline Gs13 & 1.8 & 5.3 & D3 & 5.0 & $\mathrm{~T} 2$ & 8 & 6.5 & 0.61 \\
\hline We22Ka10 & 2.5 & 3.8 & D4 & 2.5 & T1 & 10 & 6.3 & 0.59 \\
\hline Cv21 & 1.0 & 5.8 & D1 & 10.0 & T3 & 6 & 5.5 & 0.32 \\
\hline & & & & & & & $\begin{array}{l}\text { Land Type } \\
\text { Suitability } \\
\text { Index } \\
\text { Value } \\
\text { (LTSIV) } \\
\end{array}$ & 20.19 \\
\hline
\end{tabular}




\section{APPENDIX C}

\section{LAND TYPE Ca6}
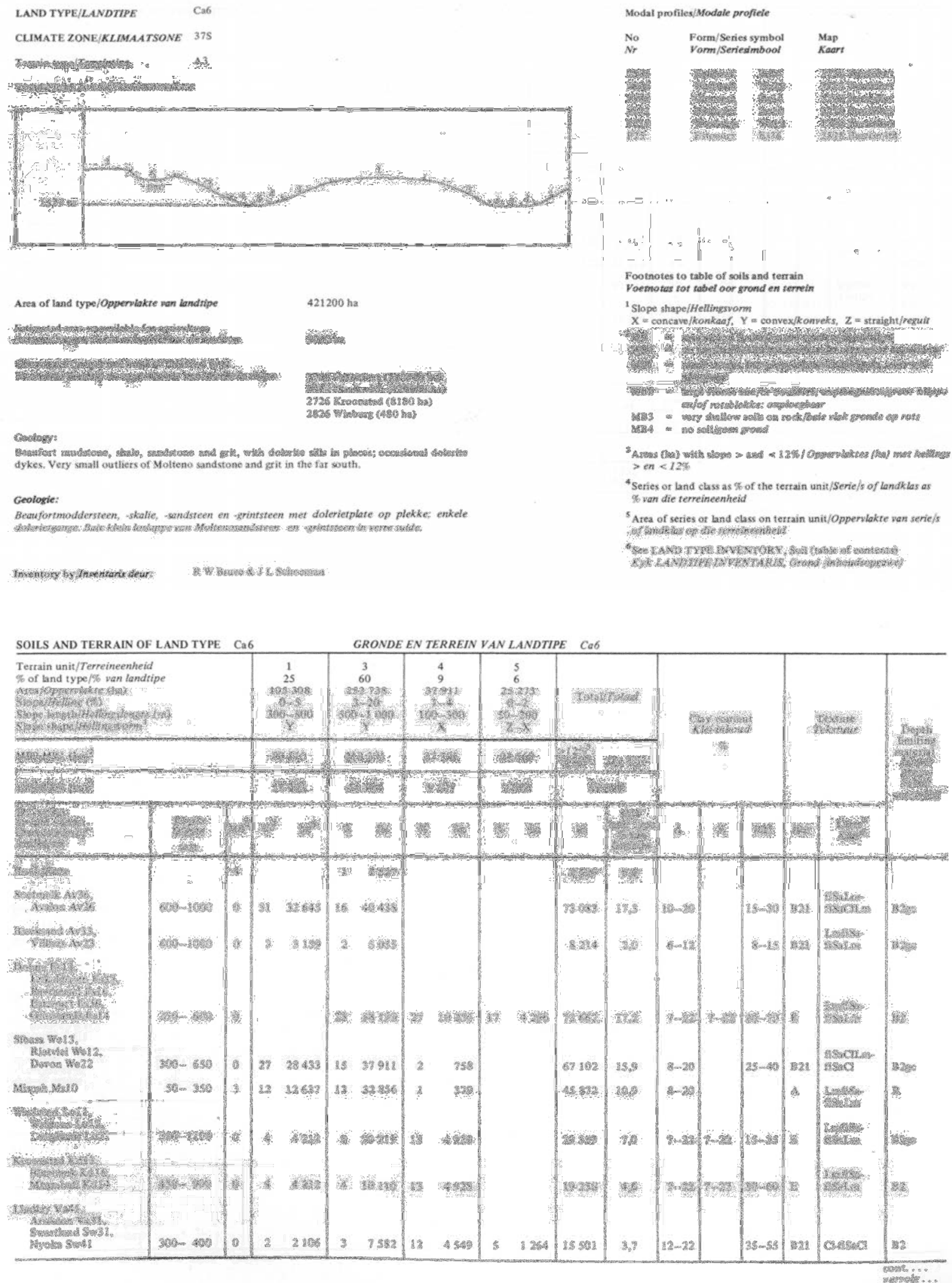

Source: Land Type Survey Staff (1984) 


\section{APPENDIX D}

\section{THE ALGORITHM'S LOOKUP TABLE}

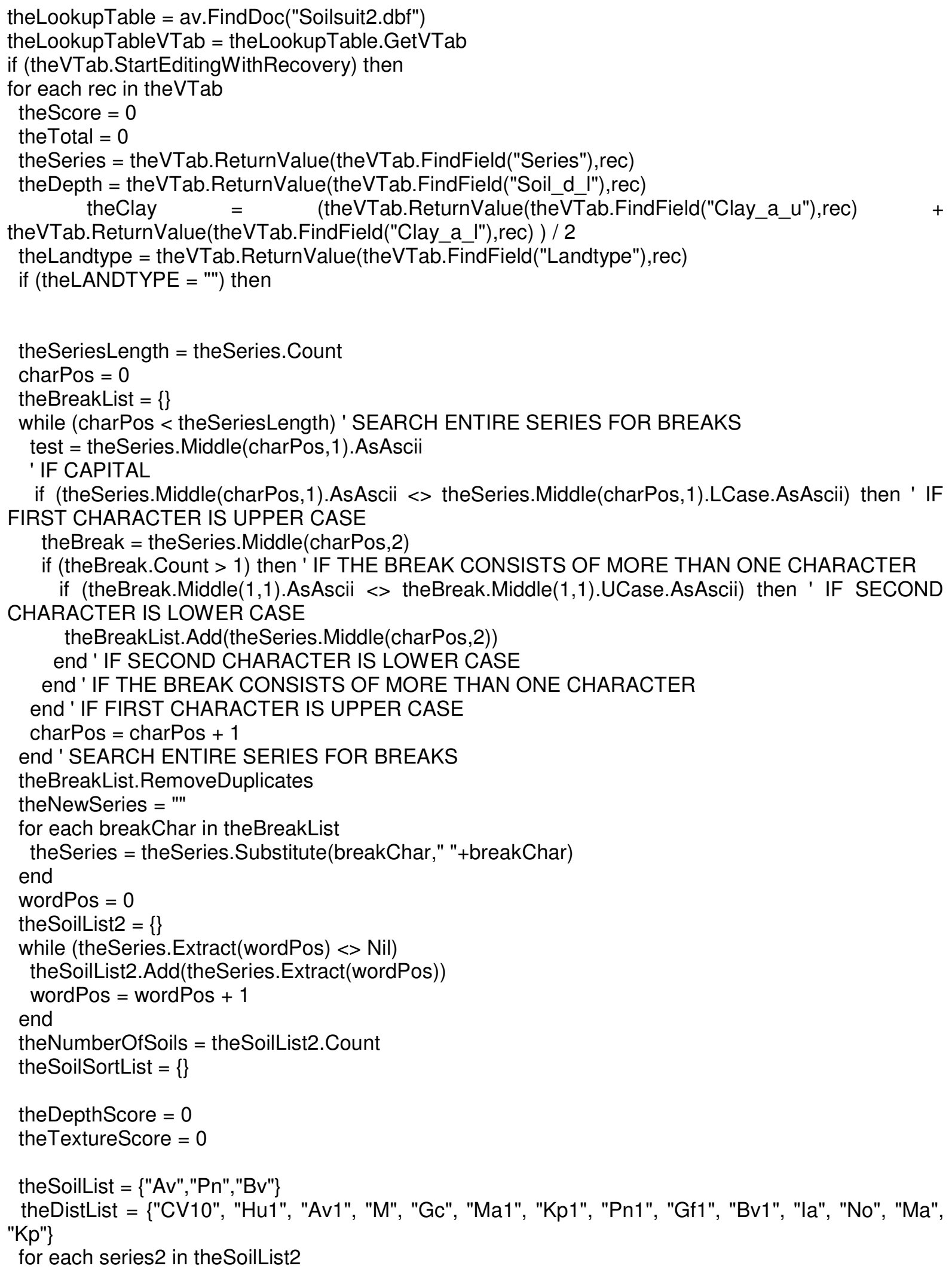




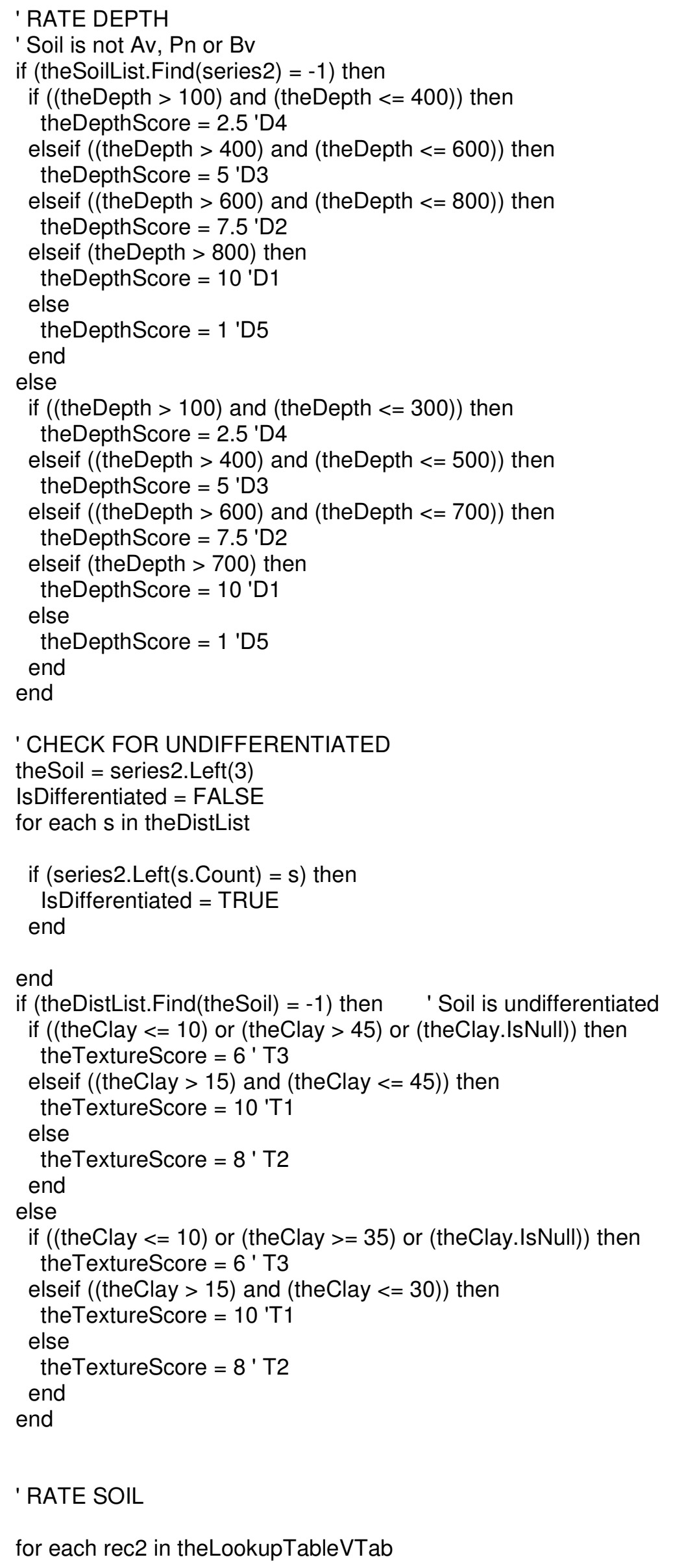




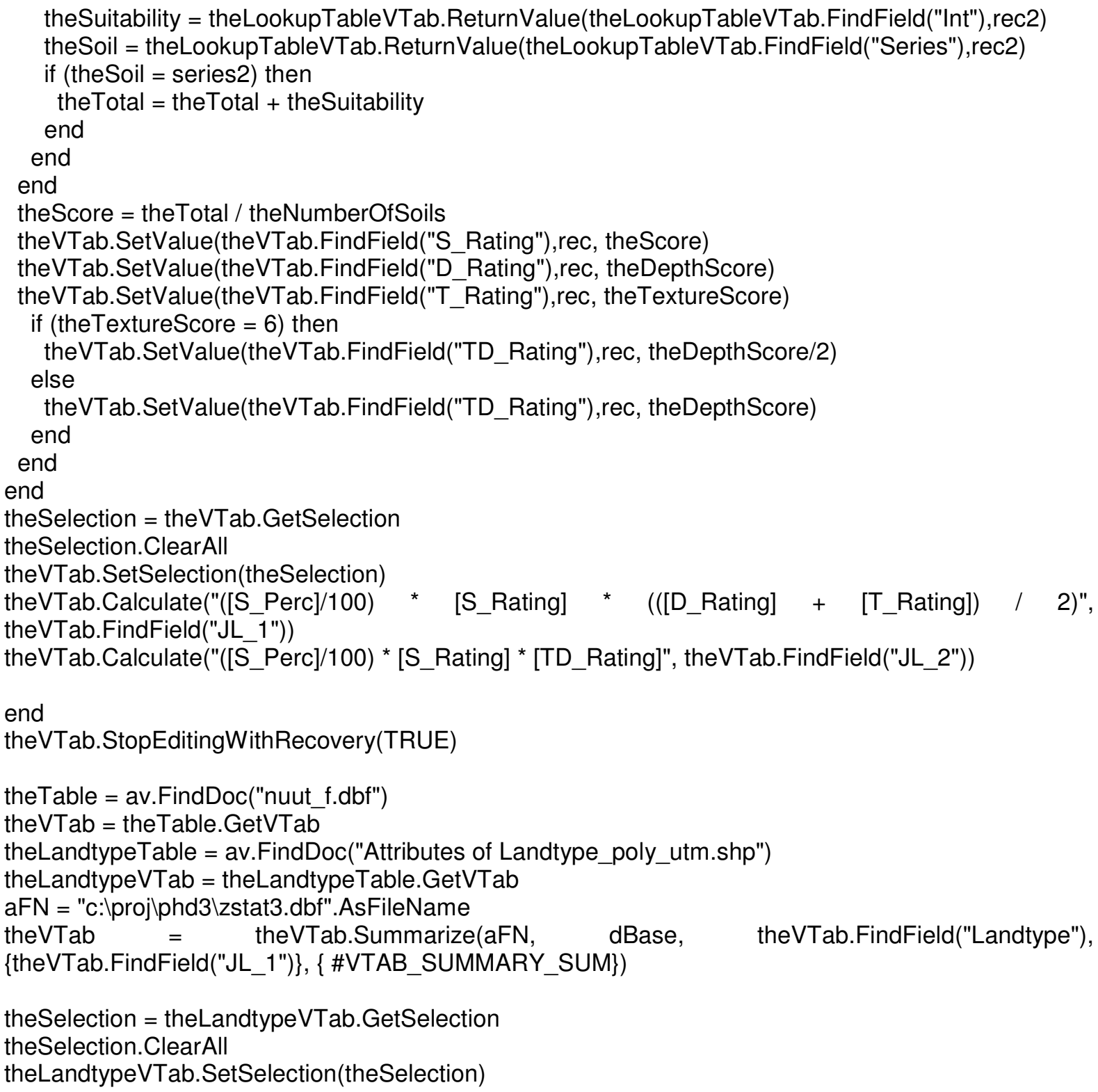

theLandtypeVTab.Join(theLandtypeVTab.FindField("Landtype"),theVTab,theVTab.FindField("Landtyp e"))

if (theLandtypeVTab.StartEditingWithRecovery) then

theLandtypeVTab.Calculate ("[Sum_JL_1]", theLandtypeVTab.FindField("JL_1x"))

end

theLandtypeVTab.StopEditingWithRecovery (TRUE)

theLandtypeVTab.UnjoinAll

theTable = av.FindDoc("nuut_f.dbf")

theVTab = theTable.GetVTab

theLandtypeTable = av.FindDoc("Attributes of Landtype_poly_utm.shp")

theLandtypeVTab = theLandtypeTable.GetVTab

aFN = "c:lprojlphd3/zstat3.dbf".AsFileName

theVTab = theVTab.Summarize(aFN, dBase, theVTab.FindField("Landtype"),

\{theVTab.FindField("JL_2")\}, \{ \#VTAB_SUMMARY_SUM\})

theSelection $=$ theLandtypeVTab.GetSelection

theSelection.ClearAll 
theLandtypeVTab.SetSelection(theSelection)

theLandtypeVTab.Join(theLandtypeVTab.FindField("Landtype"),theVTab,theVTab.FindField("Landtyp e"))

if (theLandtypeVTab.StartEditingWithRecovery) then

theLandtypeVTab.Calculate ("[Sum_JL_2]", theLandtypeVTab.FindField("JL_2x"))

end

theLandtypeVTab.StopEditingWithRecovery (TRUE)

theLandtypeVTab.UnjoinAll

Dr Adriaan van Niekerk

Director: Centre for Geographical Analysis

Geography \& Environmental Studies, Stellenbosch University

Chamber of Mines (Geology) building, Cnr of Merriman Avenue and Ryneveld Street, Stellenbosch

http://www.sun.ac.za/geo or http://www.sun.ac.za/cga 